

\section{Cornell International Affairs Review}

\section{Faculty Advisor}

- Professor Ross Brann,

Department of Near-Eastern Studies

\section{Board of Advisors}

- Professor Peter Katzenstein, Department of Government

- Professor Isaac Kramnick, Department of Government

- Professor David Lee, Department of Applied Economics and Management

- Professor Nina Tannenwald, Brown University

- Professor Hubert Zimmermann, Department of Government

\section{Executive Board}

- Gracielle R. Cabungcal, President

- Luis-François de Lencquesaing, Vice-President

- Ryan S. Spagnolo, Vice-President

- Karl Chan, Director, Layout

- Darian Singer, Director, Layout

- Anetta Pietrzak, Director, Public Relations

- Mitchell Alva, Director, Global Networking

- Dening Kong, Director, Finance

- Timothée Neron-Bancel, Director, Finance

- Brian Druyan, Secretary

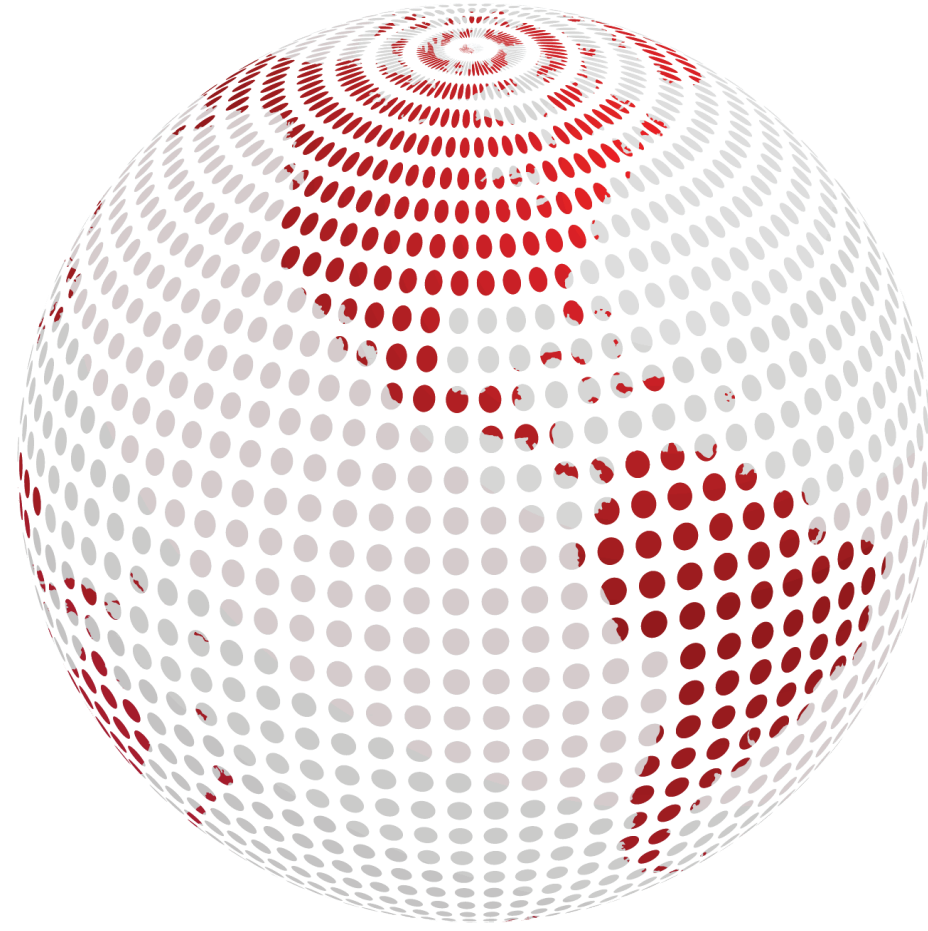

Cornell International Affairs Review, an independent student organization located at Cornell University, produced and is responsible for the content of this publication. This publication was not reviewed or approved by, nor does it necessarily express or reflect the policies or opinions of, Cornell University or its designated representatives. 


\section{Letter from the President}

In the summer of 2007, Cornell University President Dr. David J. Skorton testified before the U.S. House Committee on Science and Technology, suggesting that "any cooperation across borders can play an important role in promoting cross-cultural understanding." Cornell has a "history of 'internationalization"', he recalled, that commits it to utilizing resources for addressing today's most pressing global issues.

In this second edition of our journal, the Cornell International Affairs Review highlights our own commitment to furthering this history of internationalization. These articles, spanning both a range of topics -- from Cornell University's role in global affairs to the qualms democratization- as well as geographical breadth - from the Caribbean and Latin America to Russia and South Asia -- provide critical assessment of issues pertinent on a simultaneously global and local stage. It is only by our network's cooperation, spanning beyond borders, that the Review achieves in what we hope is an insightful awareness of our global community.

The publication of our most recent issue serves as a milestone to the Cornell International Affairs Review. Special thanks to all those who have helped us achieve so much: our advisor Ross Brann, our advisory board, our patrons, and our external contributors, whose guidance and contributions have proven invaluable; our staff, who works tirelessly in maintaining a stimulating intellectual community even beyond the words on a page; and you, our readers, whose support keeps the Review's mission alive.

Carl Becker, Cornell Professor of History from 1917-1941 and a man who himself added to the University's rich historical tradition, once said that "everyman...reaches out into the distant country of the past. Without this historical knowledge, this memory of things said and done, his today would be aimless and his tomorrow without significance."

The following pages celebrate the Cornell International Affairs Review's own short yet dynamichistory. Through this Review, we seek to frame ourvision for creating a vibrant community dedicated not only to discourse and intellectual engagement, but also and, fundamentally, to cooperation for change. It is our hopes that in enjoying these articles and celebrating with us, you are encouraged to reach into your own past, examine its complex interactions with the global community, and join us in making tomorrow a tomorrow of significance for yourselves, for each other, and for the world. 


\section{Editorial Note}

The Cornell International Affairs Review is committed to providing an international, interdisciplinary and intergenerational approach to world affairs. We believe that bringing together perspectives of students from different countries and majors, undergraduates and graduates, with the wisdom of professors and the vision of policy makers contributes in an original way to the debate on foreign policy. This approach is reflected in our second issue, as well as in the forums we have hosted on campus, "Global Politics: Will Regions Count in the $21^{\text {st }}$ Century?" with Professors Peter Katzenstein and Hubert Zimmermann and "The Challenges of the European Financial Integration," with French Banker Edouard de Lencquesaing.

The journal brings forth thoughtful reflection of the current forces shaping our global community through the collaboration of our authors. As you will see, the diversity of our writers reflects the extent to which this organization aspires to engage the world around us. Drawing from a variety of specialty areas, ranging from transitional justice in human rights to transatlantic currency instability, from US democratization policy to economic dynamics in Haiti, we seek to diversify the content of the review as a testament to the long-reaching international scope of these forces.

We are honored to include in this issue a call from Cornell University President David Skorton for a "Marshall Plan for Higher Education," along with articles from Cornell Professors Ferri and Zimmermann, from University of Massachusetts Professor Goldsmith, and from Cornell and Sciences Po Paris students.

Dr. Skorton's vision of the "American University" as a crucial diplomatic asset for the United States, and as a tool to address the challenges of our century, resonates strongly with our beliefs. Universities and research institutions should play a more important role in foreign policy. These transnational actors not only provide technological progress that affect the socioeconomic problems of the world -from agriculture to engineering-but are centers of debate that forge the foreign policy and economic doctrines of our governments. We hope that this discussion will be pursued on our campus, in Washington and in other capitals.

We seek to promote a wider academic community, connected and engaged in thoughtful and informed debate of these international and transnational issues. In this way, we lead the charge to bring an international outlook to all Cornell students, regardless of major or school, and involve them in learning more about the world beyond them. The world we live in is very fluid and dangerous. It is our responsibility, as students and as citizens, to engage in the foreign affairs debate, and to attempt to provide solutions to make the $21^{\text {st }}$ century a century of peace.

Luis-François de Lencquesaing

Cornell University, Arts and Sciences, 2010

Vice-President, Cornell International Affairs Review
Ryan S. Spagnolo

Cornell University, Arts and Sciences, 2009

Vice-President, Cornell International Affairs Review 


\section{U.S. Policy Towards Colombia}

Andrew Kao, Cornell University, 2011

Sean Sangsub Lee, University of California, Berkeley, 2011

\section{Justice}

Evasive and Amorphous

Harin Song, Cornell University, 2010

Indo-Pakistani Enmity \& the Reorganization of Asia

Strategic Opportunities for China and India

Soleine Leprince-Ringuet, Sciences Po, Institut d'Etudes Politiques de Paris, 2009

\section{The Russian Government and Gazprom}

Philip Nahernak, Cornell University, 2010

John Simpkins, Michigan State University, 2010

\section{Rising Euro, Falling Dollar}




\title{
Global Outreach Plan for Colleges
}

\author{
Dr. David J. Skorton \\ President, Cornell University
}

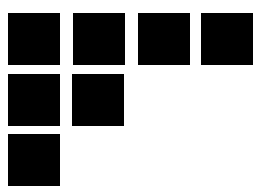

Dr. David J. Skorton, president of Cornell University, first introduced the idea of a new initiative emphasizing the international development of human capacity through the dissemination of university research, teaching and outreach at his first commencement address to the graduating class of 2007. Since then, the idea has inspired several conversations between Dr. Skorton and other academicleaders and institutions looking to effect change, including the U.S. Agency for International Development (USAID) and the National Association of State Universities and Land-Grant Colleges. He is also participating in the upcoming Higher Education Summit for Global Development with Secretary of State Condoleezza Rice, Secretary of Education Margaret Spellings and Administrator for USAID Henrietta Fore, the goal of which is to develop strategies to establish new and enduring higher education relationships for international development. These conversations help to galvanize the issue of eradicating international socioeconomic inequalities.

Dr. Skorton recognizes and appreciates Cornell International Affairs Review's "international, interdisciplinary and intergenerational approach to world affairs." With his permission, the following article, which was first published in the September 21,2007 issue of The Chronicle of Higher Education, is reprinted to continue the critical discourse on the development of human capacity around the world.

Speaking at a Harvard University commencement 60 years ago, Secretary of State George C. Marshall proposed a massive program of aid and redevelopment - since known as the Marshall Plan - to bring a warravaged Europe back to economic health, political stability, and peace. Today we need a new such plan, with university teaching, research, and outreach at its center, to help resolve the socioeconomic inequalities that threaten our country and the world. At a time when other nations are challenging the United States economically as well as on religious, moral, and ideological grounds, we should enlist our colleges and universities to fulfill their potential as one of our most effective and credible diplomatic assets.

The World Bank has estimated that more than 2 billion people worldwide currently live on less than $\$ 2$ per day. More than 1 billion people lack access to good water sources, and 42 percent of the world's population, or 2.6 billion people, don't have access to proper sanitation, according to the World Health Organization. About 146 million children in the developing world are malnourished, Unicef data show, and more than 10 million children under the age of 5 die each year, many from causes that would be preventable with better nutrition and access to basic health care. Such dire situations represent a humanitarian crisis of the first order and - as our world is becoming smaller and more interconnected - a threat to stability, intercultural understanding, and peace.

In his speech at Harvard, Marshall stated: "It is logical that the United States should do whatever it is able to do to assist in the return of normal economic health in the world, without which there can be no political stability and no assured peace. Our policy is directed not against any country or doctrine but against hunger, poverty, desperation, and chaos." 
The United States offered about \$140billion in today's dollars to support Marshall's proposal, but only if Europeans drew up a rational plan for using the aid and agreed to act cooperatively. The resulting Marshall Plan was shrewd and visionary and, at the same time, informed by enlightened American self-interest and a capacious national sense of "self." The results were unprecedented, and we continue to benefit from its wisdom to this day.

Since 1947 there have been numerous calls for new Marshall Plans to deal with needs throughout the world - in Africa, Central Asia, Eastern Europe, and elsewhere. Much of the work and resources must come from governments through traditional vehicles, like the U.S. Agency for International Development, as well as promising new ones, like the Millennium Challenge Corporation, a U.S. government corporation established in 2004 to provide assistance to countries in order to achieve specific development objectives.
But colleges and universities can and should play a more central role in helping countries that are struggling to meet the needs of their citizens by improving local education, research, and problem-solving skills. Indeed, the development of human capacity is not only one of the most effective ways to ameliorate global inequalities, but it is also a prerequisite for any enduring improvement of the standard of living at the local level, where it matters most.

No single college or university, acting alone, can achieve what will be needed in tomorrow's world. Together, however, the nation's great research institutions - public and private, land-grant and Ivy League, working with the U.S. government, businesses, foundations, nongovernmental organizations, and, most important, our academic colleagues overseas - can offer a more focused application of our own resources to reach out, materially and directly, to assist and improve the quality of life.

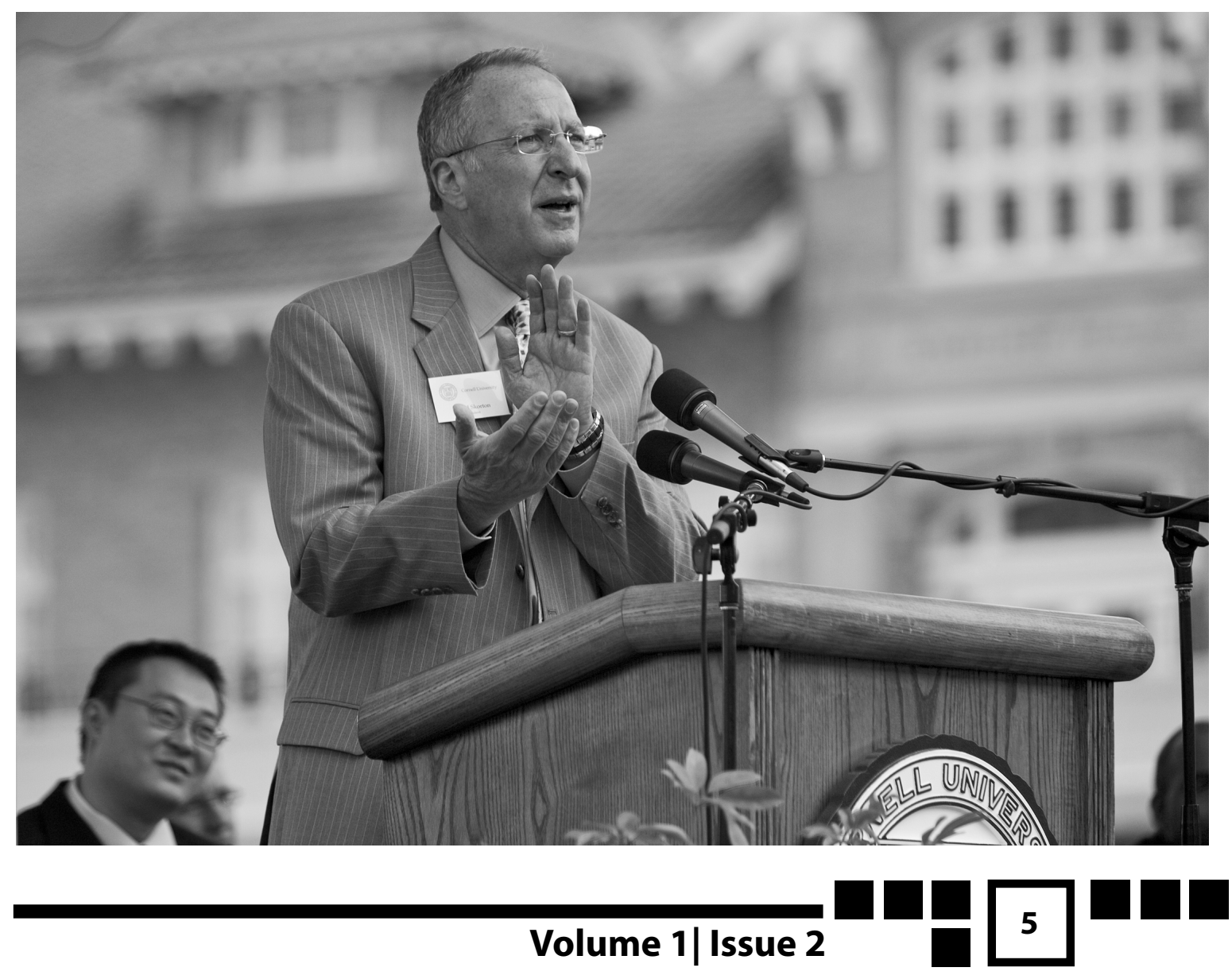


American colleges and universities are a beacon of hope and opportunity throughout the world because of the transformative power of our education, best captured by the old proverb: Give a child a fish, and she will eat for a day. Teach a child to fish, and she will feed herself, and perhaps also her family and community, for a lifetime.

The reality is that there is not enough capacity worldwide to satisfy the spiraling demand for higher education, which is fueled by the needs of an exploding global middle class - particularly in China and India - and the collapse of Africa's higher-education infrastructure. That leaves a growing number of capable students with no options to pursue their education. Simply put, we cannot handle tomorrow's students and the demands for advanced skills with the resources that exist today.

In the United States, we can tap the strengths of higher education to develop a new kind of plan to deal with this challenge. First, the many research and land-grant colleges and universities should coordinate their current efforts in capacity building in the developing world, perhaps through intercampus agreements or professional associations like the National Association of State Universities and Land-Grant Colleges.

Second, our colleges and universities should collaborate to develop a strategic research and education agenda that complements issues of concern to similarly oriented NGO's, corporations and foundations, and our counterparts overseas, in areas such as nutrition, global health, sustainable technologies, and conflict resolution. Following the introduction of President Harry S. Truman's Point Four program in
1949, which extended the Marshall Plan to the world's developing countries, Michigan State University's president, John A. Hannah, informed the White House that institutions in the Association of Land-Grant Colleges and Universities (now called the National Association of State Universities and LandGrant Colleges) were willing to contribute to the effort. Within three years, eight of those universities were involved in technicalassistance programs overseas, and by 1964 , more than 150 such programs were under way. A similarly focused effort by universities today might be directed toward NGO's or private-sector entities that support work in important fields.

Ultimately, we should develop a comprehensive strategy with global reach to guide and assist governmental efforts of the United States and other nations. We should redouble our efforts to make the White House and Congress aware of the role that universities can play in international development and why public support for university-led capacity building overseas is in the national interest. Presidents, provosts, government-relations staff members, faculty members, and trustees can all serve as effective advocates for such efforts in the public-policy arena.

The stakes are as high today as they were 60 years ago - and perhaps even higher; the explosive international situation must be redressed for the benefit of the worldwide community. Echoing President Truman when he explained his support of the Marshall Plan, we must undertake this effort "because it is right" and "because it is necessary to be done, if we are going to survive ourselves." 


\section{Cornell \& the Marshall Plan (1947-1951)}

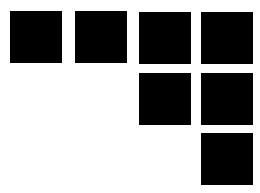

Since his nomination as Cornell University's twelfth President, Dr. David Skorton has made a "Marshall Plan for higher education" one of the cornerstones of his tenure. In his first Commencement Address on May 27, 2007, he said:

\begin{abstract}
"The U.S. must provide leadership, as it did in the rebuilding of Europe after World War II. Sixty years ago... on June 5, 1947, U.S. Secretary of State George Marshall, speaking at a Harvard Commencement, suggested the need for a massive program of aid and redevelopment for Europe that came to be known as the Marshall Plan. In his speech, General Marshall said: "Our policy is directed not against any country or doctrine, but against hunger, poverty, desperation and chaos". And he stressed that the plan for European recovery had to be a joint one, involving the nations of Europe, rather than being imposed unilaterally by the U.S.... The result was unprecedented international cooperation that created what continues to be seen as an economic - and political - miracle... Over the years there have been many calls for new Marshall Plans to address various needs elsewhere in the world. But none of the plans of which I am aware has grasped the potential of universities, through comprehensive programs of teaching, research and outreach, to assist countries struggling to meet the needs of their citizens."1
\end{abstract}

To be sure, there have been many calls for new Marshall Plans since 1947. As a matter of fact, the Marshall Plan idea has been subject to episodic appropriation down the years for projects as diverse as the "war on poverty" in American cities and Third World development projects and environmental clean-up... The
Marshall Plan is interesting as a metaphor for directing foreign-policy discussions ... It has come to signify a kind of bold American initiative [involving consultation and multilateralism, as opposed to imperialism]. ${ }^{2}$ President Skorton is correct, however, when he claims the originality of his own plan, which focuses on higher education. Whatever the limits of analogies and comparisons, it may be interesting to go back to the period 1947-1951, to see what role Cornell played during the actual Marshall Plan.

The European Recovery Plan (ERP) was in operation from January 1948 and up to December 31, 1950 - which is not to say, of course, that the American aid to Europe started in 1947-48. ${ }^{3}$ While the range of its impact on the "miraculous recovery" of wartorn Europe is still a matter of debates among historians, there is no doubt whatsoever that the "Marshall Plan" was a huge politicalpsychological encouragement to Western Europe, and a major stimulus to its political integration through the economy, starting with Robert Schuman's speech in Paris in 1950 proposing common European control over steel and coal. The Marshall's proposal was revolutionary in that, from the very start, it required mutual cooperation among the sixteen countries that responded to the invitation to participate in the ERP program. ${ }^{4}$ They constrained themselves and joined together to improve the economic condition of almost 300 million people.

It is also obvious that the Plan has to be placed in the context of the Cold War. Although initially it was not Secretary Marshall's intent to make the ERP an instrument in a war of ideologies between the Soviet 
Union and the United States, ${ }^{5}$ it was clearly aimed at demonstrating the superiority of a Weltanschauung over all the others. As Bruce Kuklik points it out,

[In the Americans' view], a prosperous Europe, oriented by the folkways of American capitalism, would limit Soviet expansion... The export of American-style political economy would blunt it... [Besides], to gain support for its expensive and unglamorous courses of action such as the Marshall Plan, the Truman administration exaggerated the propensity of the Soviet Union, and Communist ideology in general, for military adventure. ${ }^{6}$

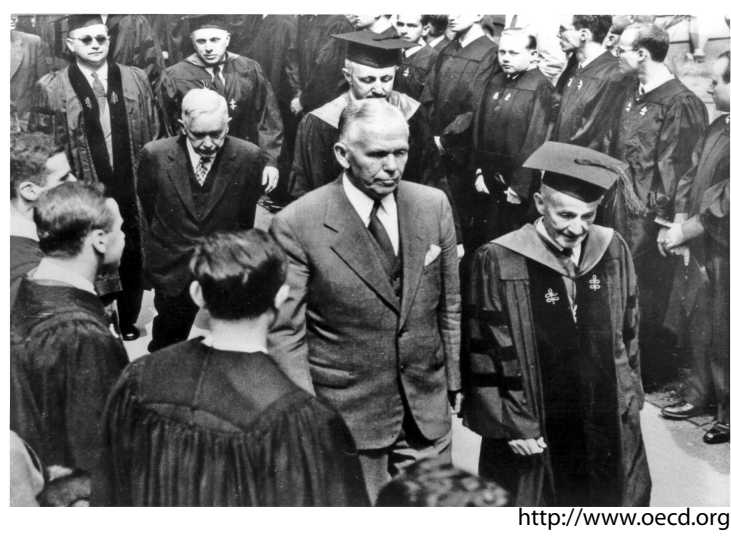

This view was not particularly that of rightwing cold warriors. An immigrant from Italy and a moderate liberal by American standards, Cornell professor Mario Einaudi ${ }^{7}$ wrote in 1951:

Communism opposes the reconstruction measures of post-war Europe because it realizes that the Marshall Plan and Schuman Plan aim to recover Europe's independence and strength vis-à-vis the Soviet Union and at the same time to reconstruct Europe's system in such a way as to eliminate some of the conditions which have led to communism.... [There is an] affinity between communism and bankruptcy and [an] incompatibility between communism and expansion and economic progress... Just as the Communists oppose the Marshall Plan because it stands for the modernization of Europe, so are they opposed to the Schuman Plan because it stands for the ideal of an open society... [Finally, they see it] as an obvious preparation forced upon [Western Europe, especially countries like France and Italy] by American imperialism. $^{8}$

One has to add an important nuance: for Einaudi, the failure of the Marshall Plan could prepare the ground for a dictatorship of "the Communists" or "the Right". In any case, the Marshall Plan and the re-militarization of Europe - including Germany - served the same goal: to create a New-Deal-like industrial democracy all around "the free world".

So, what was Cornell's role in the reconstruction of Europe along these lines? At first sight, there was no obvious reason why this venerable Ivy League institution founded in Ithaca in 1865, and often described as the ivory tower par excellence, should be involved in any way. With the Hoover report revealing the tragic condition of hunger, unemployment, and homelessness under which many millions of people were still living, neither Harry Truman's Address on October 24, 1947 ("World needs must be met"), nor General Marshall's speech on "the requirements for the rehabilitation of Europe" mentioned universities, science and knowledge in general. That the reconstruction of laboratories and educational facilities, and the furnishing of equipment and libraries in the war-devastated countries were essential for lasting world peace was certainly not a reality that was ignored in memos and speeches. But the primary focus and rationale were elsewhere. Interestingly enough, "science" was initially re-introduced as an aspect of the Marshall Plan at the suggestion of the military-industrial complex, with Vannevar Bush, nicknamed "the patron saint of American science," ${ }^{\prime 9}$ as a major exponent of the new policy.

On the other hand, a colossal effort like the Marshall Plan could not be accomplished without the support of universities, a key- 
element of the American society and of its influence/prestige abroad. It is impossible to even mention, within the limits of this article, all the individual contributions made by Cornellians to the reconstruction of Europe. Some were actually discreet, yet important on a symbolic level. For example, in her account of "Senior Year 1945-46", a Cornell student did not omit the fact that

In the spring we ran a model U.N.O. and tried a Share-Your-Share Diet in the dormitories one meal per week to raise money to send food to Europe. ${ }^{10}$

Other initiatives in which Cornellians participated, such as the illustrious Salzburg Seminar, ${ }^{11}$ show that it was possible (though very difficult) to retain the idea of American-European academic cooperation while rejecting the Cold-War ideology and questioning some (not all) "American values."

Here, I choose to emphasize what, in my view, were Cornell's main contributions as an institution. Cornell was part of the adventure of the Marshall Plan as a forum of ideas, a provider of scientists and technical advisors, and finally an actor of the academic cooperation and the reconstruction of science in Europe after WWII.

\section{Cornell as a Forum of Ideas Making Plans}

At least two Cornellians were directly involved in the design of the Marshall Plan. The first one was Edward Whiting Fox. The quintessential preppy WASP, Fox had earned his A.B., M.A., and Ph.D. degrees in historical geography from Harvard, where he was the student of Professor Francis O. Matthiessen. ${ }^{12}$ An Assistant Dean from 1941 to 1945 (and the father of future feminist, conservative historian Elizabeth Fox-Genovese), he was appointed to the U.S. Department of State by President Franklin Roosevelt, and served as Assistant Secretary of State for policy analysis in the Truman administration from 1945 to the fall of 1946, when he joined the Department of History at Cornell. However, he stayed in touch with some people within the Truman administration. Fox's assumptions about "tradingnations"and"societies'(un)openness"13 were somehow reflected in the Marshall Plan (a transatlantic approach of world business), although his personal influence shouldn't be exaggerated.

Professor William I. Myers's involvement is better-known. A famous agronomist, Myers had been Henry Morgenthau's academic adviser when the illustrious statesman studied agriculture (and architecture) at Cornell, before he dropped in order to run a farm. When Morgenthau ${ }^{14}$ was made Governor of the Federal Farm Board, with the special task of establishing a comprehensive, reliable system of farm credit, Myers became his technical advisor, and he co-wrote the Emergency Farm Mortgage Act (1933). Fourteen years later, while Dean of the Cornell College of Agriculture (since 1943), Myers, whose idée fixe was "to foster an Americanized world agriculture,"15 was appointed a member of the Harriman Committee, along with Chester Davis of the Federal Reserve Board, William L. Batt, the head of the War Economics Board, and other so-called "business liberals." They wanted to draft the ERP as an aid program that would go beyond relief and recovery to actually "reconstruct the economic base of Western Europe, with business practices more in line with US corporate models. [They] forwarded an initial set of findings and recommendations to Congress in December 1947 that acted as the basis for the drafting of a legislative aid package." 16

\section{Championing the Marshall Plan}

Not only did Cornell provide ideas, frames, and figures. The University also served as a source of intellectual legitimization, especially with regards to the "Cold War" aspect of the plan. That was particularly true under acting President de Kiewiet ${ }^{17}$, whose 
tenure coincided with the first conflict of the Cold War, in Korea. We are struck today by the rhetorical restlessness of that time. While De Kiewiet spoke proudly of himself as "a scholar of the world," he was praised by Chancellor Day as "a militant spokesman for educational leadership in combating communism". In his Commencement speech on June 14, 1948, he drew a parallel between the current situation and the Greek-Persian War: "If the Persians had defeated the Greeks, it is certain that the great flow of ideas which produced the modern democratic spirit would have dried at its source."18 Chapter 4 of his 194849 report to the Cornell Board of Trustees ${ }^{19}$ was entitled "No communists as teachers", chapter 10 was entitled "Freedom must be defended" and emphasized "the responsibility of higher education for the protection of our American Way of Life". When U.S. President Truman proclaimed the existence of a state of national emergency due to the war in Korea (which had begun in June 1950, and whose escalation would lead to the end of the ERP), Cornell Vice-President Theodore P. Wright was named Chair of a "Defense Coordinating Council," whose meetings seem to have been particularly bellicose in tone. On Sept. 11, 1950 , for instance, the council reflected on "the need to identifying clearly and consistently what it is that the U.S. and the United Nations are defending and fighting for." Attached to the minutes of another meeting held on Dec. 19,1950 is a list of the existing or planned research centers that could "obtain support in the University's National Defense Effort," such as Aerial Photography, Air Safety, Animal Virus Diseases, Nuclear Tactics, Rockets and Rocket Fuel, but also Foreign Languages and Social Sciences. ${ }^{20}$ It does not come as a surprise, then, that this Cold War University President publicly supported a bold statement by the American Committee on United Europe. According to the authors, the Marshall Plan had prevented the Communists from seizing power in Western Europe. Now, they asked that the U.S. Government "[send] to Western Europe additional forces" and "encourage the French plan for building an unified European Army to fight under Eisenhower's command."21

The Office of the President was not the only source of legitimization of the U.S. foreign policy. One can mention, for example, the participation of Solomon Cady Hollister, Dean of the College of Engineering, in a Scientific Advisory Committee whose public report claimed, "We must be prepared... to assume leadership of many kinds in a world torn apart" (Dec. 18, 1950); or the fact that the earliest example of an official history of the Marshall Plan was published by the Cornell University Press, under the auspices of the Governmental Affairs Institute" in Washington, DC. ${ }^{22}$

\section{Attacking the Marshall Plan}

At the same time, Cornell's Presidents tried their best to support academic freedom and free speech. It was especially difficult during the McCarthy Era (as witnessed by what happened on othercampusessuch asBerkeley), when President Malott, a businessman and a self-defined "extremely conservative person" was "caught in the middle of a passionate debate, trying to please the Board of Trustees, who did not wish to see the University face a lot of negative publicity," while preserving the quality of scholarship, ${ }^{23}$ and even "the essence of the institution." 24

In the case of the Marshall Plan, the opposition on Cornell campus came from two different parts. There was the traditional opposition from the part of "isolationists." One of the most vocal opponents to interventionism in Cornell was Curtis P. Nettels, who taught American history since 1945. Nettels affirmed that "the federal government is not an agency for dispensing charity to foreign lands" (Wall Street Journal, November 18, 1947), that the Marshall Plan was nothing more than "the idea of the New Deal, applied to foreign affairs" (Ithaca Journal, Sept. 26, 1947), that it disproportionately favored Europe at the expenses of the rest of the world ("LatinAmerican people do not like the message 
that Europe comes first", Ithaca Journal, April $21,1948)$; in a final shot, he claimed that his opposition to any "super State" made him at odds with "the imperialist school" (Senate public hearing, May 17, 1949). But Nettels'views were generally regarded as unconvincing, and the American aid to Western Europe was utterly popular. ${ }^{25}$

Then, a specifically-aimed furor inflamed Cornell, which spread nationally. It had to do with the reconstruction of science in Germany and Austria, and started with the rumor (?) that anti-Nazis were dismissed and Nazis promoted in U.S.-sponsored scientific institutes in Germany. Clarence G. Lasby has found a letter dated February 28, 1947, sent by a Cornell physicist to a colleague in the University of Chicago.

Two or three items: The Nazi scientist deal. You heard the Cornell story: plenty of outside pressure behind appointing a man who turns out OK. Was chief of a big German industrial lab, has friends here. Worked in a concentration camp, head shaved, wearing prison dress, since 1943 on electronics research. Or so the Gestapo thought. He seems to be an anti-Nazi [in fact, the War Department sought a position for him at Cornell, because he was much too outspoken and disliked by his colleagues in Germany, LF] ...Cornell may appoint him on a trial basis. ${ }^{26}$

An infringement to the sacrosanct hiring practices within the academy, with pressures by the Federal Government, had re-ignited the debate on Germany's post-war reconstruction! In the April 1948 issue of the Bulletin of American Scientists, Cornell physics professor and antinuclear activist, Philip Morrison, wrote that "German scientists worked for the cause of Himmler and Auschwitz, for the burners of books and the takers of hostages." 27 This provoked an outraged response from Max von Laue, Nobel Prize in Physics 1914, who had courageously opposed the Nazis and their Deutsche Physik (like few others, indeed), and yet had been interned in England almost one entire year
(1945-46). For him, "the good Germany" was entitled to monetary and scientific support.

In short, there were also attacks against and controversies about the postwar efforts to reconstruct Western Europe according to American standards. And yet, dissensus was rare: most U.S. citizens still held optimistic views of Western Europe, despite the Holocaust; besides, "political apathy was the price many students [and faculty members] paid for becoming integrated at Cornell." ${ }^{28}$

\section{Cornell as a Provider of Scientists and Technical Advisors}

Another way for Cornell to be part of "the Marshall Plan" was, of course, to provide Western Europe with knowledge, techniques, and technicians (about 15,000 U.S. specialists and consultants served in Western Europe in the direct implementation of the national programs created by the Marshall Plan). Cornell proved a leader in three fields in particular: agri-business, virology/bacteriology, and statistics applied to business.

\section{Agricultural Engineering and Agri-business}

Agriculture was a major concern for the Marshall planners. In a statement in December 1948, U.S. President Truman said, "I know of no one factor more important to the future peace of the world than food. The work the F.A.O. [the United Nations' Food and Agriculture Organization] does, or leaves undone, will have a great bearing on the history of the world." Besides the fact that needs must be met with regards to sufficient nutrition and food security, there was this common-sense idea that "a hungry man is an angry man," hence a potential Communist. And thirdly, what was at stake was the standardization of the harvest procedures, the merchandizing, and the consumption habits, that would benefit the American farmers and the American agri-business. That is why the U.S. Department of Agriculture asked Cornell, as a land-grant university located in a rural county, "to make available various resources 
of your institution not only to committees and groups in your area," but abroad (April 19, 1950). While the Chairman of the U.S. National Commission for UNESCO made sure that Cornell would be part of the program "Food and People,"29 many Cornell faculty members were employed as consultants, such as Max E. Brunk, Agricultural Economics (1947-1982), an expert in mechanization, pre-packaging and merchandizing, who worked with the supermarket industry ${ }^{30}$. Graduate students were encouraged to serve abroad (in the case of Cornell, most of them went to Asia, where Cornell professor Harry $\mathrm{H}$. Love was a prominent figure). Official announcements for the College of Agriculture indicated that

The international situation is such that the Federal Government provides opportunities in foreign service for qualified graduate of the College of Agriculture. They may be in either the Office of Foreign Agricultural relations in the department of Agriculture or in the Department of State.

\section{Virology and Bacteriology}

To mention but two names: in 1951, chemistry Professor John R. Johnson served for a year in West Germany as special consultant to the U.S. State Department. He had already contributed to the anti-malarial program, and was a consultant to the Penicillin Program between 1941 and 1945. Alice C. Evans served as a dairy bacteriologist for the United States Department of Agriculture and for the United States Public Health Service, but she was also frequently solicited by European colleagues. An unanswered request from a Czech scientist in 1949 shows the difficulties of working across the iron curtain, with people from countries whose authorities had declined to be part of the Marshall Plan, under Soviet pressure ${ }^{31}$.

\section{Statistics Applied to Business}

A remarkable study published in January 2005 has pointed out the major role played by the Bureau of Labor Statistics in the reconstruction of Europe:

\begin{abstract}
BLS was not only capable of using its statistical measures to identify problems of inefficiency, but also could instruct Europeans in the most modern American industrial practices. Surveys discussed in technological literature and, more directly, plan-organized plant visits supplemented BLS instruction in statistical measurement. ${ }^{32}$
\end{abstract}

Among the statisticians was William Duane Evans, who would teach in the new School of Industrial and Labor Relations along with other ex-"Marshall planners."33

W. Duane Evans, Chief of the BLS Office of Labor Economics, was appointed adviser to the Anglo-American Council on Productivity. Evans oversaw the work of James Silberman, Chief of Productivity and Technology Development, and his colleague Kenneth Van Auken. Silberman and Van Auken were sent to England and then to France in May 1948, shortly after passage of the European Recovery Program. Their assignment was to investigate industrial production in each country. After visiting 35 factories in 5 or 6 industries in England, Silberman pinpointed inefficiency in production management as the major problem.

In a typescript report entitled "Survey of French Productivity", James Silberman wrote:

The unwillingness of plant managements to visit other French plants, or be visited themselves (to guard their secrets of production), is wholly different and less effective than the free exchange of ideas found in American plants. ${ }^{34}$

\section{Cornell and the Academic Cooperation}

In this last section, I would like to show that the Cornell's participation to academic cooperation and reconstruction of science in Europe did not limit itself to "the Marshall Plan" stricto sensu. 


\section{Participation in international organizations}

In April 1945, delegates of 32 United Nations and of 19 educational organizations urged that the San Francisco Conference pledge itself to establish an International Agency for Education. And yet, already in the same year, the Institute of Teachers College at Columbia University had already abandoned the idea:

\begin{abstract}
What the world needs more than common textbooks, common curricula and courses of study, or even an International Agency for Education with the grandiose functions which are proposed for it, is a change of spirit and a readiness to put forward the same efforts and to make the same sacrifices for the constructive but less spectacular daily tasks of peace as for the waging of destructive wars.
\end{abstract}

Based on the assumption that "the role of colleges and universities is international understanding," Cornell joined the movement to create an International Organization of Universities in 1949. The university also gave its support to the Commission for International Educational Reconstruction (CIER), mostly funded by the Carnegie Corporation (194648). Finally, it worked with the UNESCO, whose headquarters were in Paris, like those of the ECA. ${ }^{35}$

\section{The Fulbright Program}

The emphasis was also on student and teacher exchanges within the Fulbright Program. This U.S. government sponsored program was created in 1946 and named after its initiator, Democratic Senator James Fulbright (1905-1995). A former President of the University of Arkansas (1939-41), Fulbright was an ardent supporter of the Marshall Plan, someone who opposed McCarthyism and "the arrogance of power." The Fulbright Program had the advantage to be based on real reciprocity, joint decision-making, and joint-funding. "The wisdom of this emerged when the steady progress made towards real reciprocity proved the program's best defense against attacks on it as the intellectual phase of the so-called imperialism of the Marshall Plan," according to Richard F. Goodings. ${ }^{36}$ However, though the ECA placed funds at the disposal of the national Fulbright Commissions, the Fulbright Program cannot be dissociated from the ERP. Richard Pells has written that it was "a sort of cultural Marshall Plan" whose "relationship... to the Cold War in Europe was underscored in 1948 when Congress provided a more comprehensive framework for America's cultural diplomacy." ${ }^{\prime 37}$ By 1948 the first Fulbright scholars traveled abroad. During our period, the program was particularly successful in Great Britain (in 1949 alone, 257 American professors and students went to the U.K. and 237 Britons to the U.S.A.) and, to a certain extent, the Scandinavian countries. One of the first Cornell students to be granted a Fulbright was John W. Reps, who went to the London School of Economics in 1950-51 and was hired as a professor of city and regional planning at Cornell in 1952.

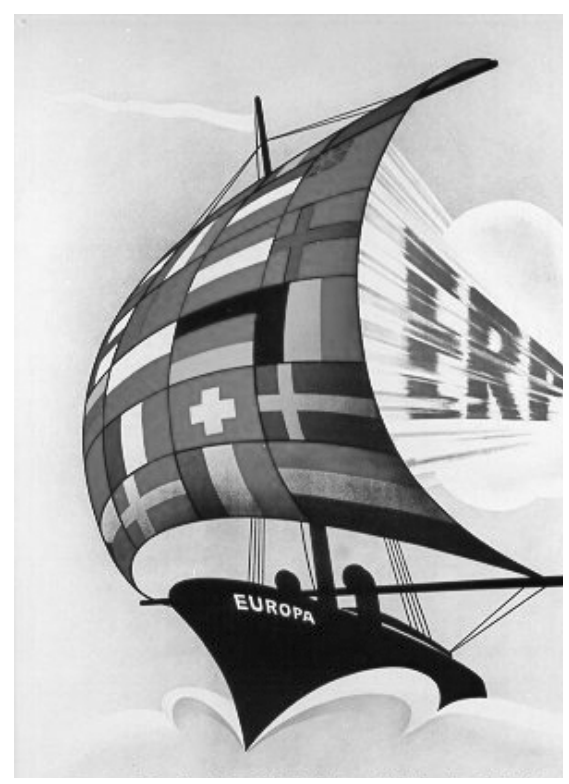

\section{Work with private foundations}

For research abroad, one major source of financing was the Rockefeller Foundation, ${ }^{38}$ to which Cornell was relatively close via Dean Myers, a member of its board of trustees of 
the Foundation. This foundation assumed the difficult task of reconstructing the physical sciences in Germany, a controversial issue as I already noticed. "On the one hand, German researchers complained about isolation, and economic deprivation of their scientific community. On the other hand, officers of the foundation were appalled by the unrepentant opportunism of some of those who applied for grants", and a campaign developed at Cornell and then on some other American campuses, against the insufficient denazification of German and Austrian science. In April 1946, Myers accompanied John D. Rockefeller III on a tour through Germany and Austria to see how to reach the right balance.

Our article shows that Cornell's involvement in the Marshall Plan was manifold. In comparison, President Skorton's own
"Marshall Plan" is both limited (thematically) and unlimited (geographically) in scope. If implemented, it may share similarities with its prestigious model. That is why Cornellians must know the history of their university - one of these "new diplomatic actors" on the rise - in order to build its future, far from any provincialism, and with the duties of privilege in mind.

The author would like to express his gratitude to the following persons: Elaine Engst, University Archivist, and his colleagues in RMC; Steven L. Kaplan, Goldwin Smith Professor of History, Patrizia Sione, Associate Archivist in the Catherwood Library, and CIAR, especially its President Gracielle Cabungcal, and Vice-President Luis-François de Lencquesaing, who speaks so eloquently of "le rôle historique de l'université américaine dans la conception, la mise en place et la critique des foreign policy initiatives."

\section{Endnotes}

${ }^{1}$ Cf. also his statements before a Congressional Committee on July 26, 2007, and in "Skorton's call for an educational Marshall Plan to address socioeconomic inequalities that threaten us all: A Global Outreach Plan for Colleges," Chronicle of Higher Education, October 19, 2007.

${ }^{2}$ Agnew and Entrikin (dir.), The Marshall Plan Today: Model and Metaphor, London: Routledge, 2004, p. 15-17.

${ }^{3}$ In fact, it was after the U.S. pumped billions of dollars into Europe for mixed results, that Truman and his advisers came to think that short-term aid was inefficient and systematic reconstruction was a far better option. Given the focus of this article, it is noteworthy that Dr. James A. Perkins, future seventh President of Cornell from 1963 to 1969, had served from September 1943 to May 1945 as Deputy Assistant to Leo T. Crowley, the powerful head of the Administration of the Foreign Economic Administration (FEA). In this capacity, he was involved in major issues such as the continuous provision of lend-lease aid to Great Britain, the restoration of free trade and private business in the liberated areas of Europe, the making of plans for post-war Germany, and, more controversially, the cut-off of all lend-lease to the Soviet Union in may 1945, an earlier sign of Cold War. Sources: Cornell Memorial Statements and the New York Times.

${ }^{4}$ Participants were Austria, Belgium, Denmark, France, Greece, Iceland, Ireland, Italy, Luxembourg, The Netherlands, Norway, Portugal, Sweden, Turkey, the UK, and West Germany. The USSR and countries under its influence declined participation; Poland and Czechoslovakia initially gave positive responses, but their participation was vetoed by Moscow.

${ }^{5}$ The recent opening of Soviet archives indicates wavering in terms of how to respond to the American invitation - strings attached, of course. According to G. Roberts, both the Soviet Union and the British contributed to the polarization and the exclusion of Eastern Europe from the program. Roberts, "Moscow and the Marshall Plan: Politics, Ideology, and the Onset on the Cold War, 1947", Europe-Asia Studies, Dec. 1994, p. $1371-88$.

${ }^{6}$ Blind Oracles, Intellectuals and War from Kennan to Kissinger, Princeton UP, 2006, p. 37-38.

${ }^{7}$ The son of Prof. Luigi Einaudi, a prominent economist and opponent to Mussolini's Fascist regime who was to become the first President of Italy (1948-1955), Mario Einaudi came to the U.S. in 1933 as a political refugee. He taught political science at Harvard before joining the Cornell faculty in 1945. While there he twice served as chairman of the Department of Government, and in 1965 he founded the Center for International Studies which is named after him. His last years were harassed with political disappointment: the 1990s saw the rise of Berlusconi and neo-Fascism in Italy.

${ }^{8}$ Mario Einaudi [with Jean-Marie Domenach and Aldo Garosci], Communism in Western Europe, Ithaca: Cornell UP, 1951, p. 42, 43 and 49. Like Truman, Einaudi seems to believe that "Communism succeeds only when there is weakness, or misery, or despair."(June 4, 1948). We could be tempted to draw analogies with some current explanations for the surge of radical Islamism in the Palestinian ghettos, but also in West-European "ghettos". The connection between poverty and extremism is in fact a complex one. Perhaps Tony Blair made a point when he said that "It is... rubbish to suggest that Islamist terrorism is the product of poverty. Of course, it uses the cause of poverty as a justification for its acts. But its fanatics are hardly champions of economic development." ("A Battle for Global Values", Foreign Affairs, February 2007).

${ }^{9}$ An industrialist and Vice-president and Dean of the school of engineering at MIT (1932-38), Bush became in 1941 director of the new Office of Scientific Research and Development (OSRD), which coordinated most of the scientific research during World War II. He was the first presidential science advisor for Roosevelt and Truman, with the title of Chairman of the Research and Development Board from June 1946 onwards.

${ }^{0}$ Barbara Alice Everitt, Cornellian 1947, p. 29.

${ }^{11}$ The Salzburg Seminar was a summer program founded in 1947 by historian Clemens Heller (born in 1917, the son of Freud's publisher in Vienna), his fellow-Harvardian Richard Campbell, and Scott Elledge, a Cornellian who was then an instructor in English literature in Harvard. Described as "the Marshall Plan of the mind", it was sponsored by the Harvard Student Council (not Harvard U.) and discreetly backed by Martin Herz, a third secretary at the American Legation in Vienna (1946-48). The seminars at Leopoldskron Castle brought together hundreds of young Americans and Europeans, including some from Socialist countries (though only Yugoslavians could make it between 1952 and 1965). The faculty included Margaret Mead, Wassily Leontief, and Francis Matthiessen. Heller himself was forced to resign in 1948 under U.S. pressure. "For much of the Cold War, the Seminar represented one of the few forums in the world where large numbers of men and women from both sides of the Iron Curtain could gather to discuss issues of common concern".

Source: http://www.salzburgseminar.org/2007/history.cfm and The New York Times. 
${ }^{2}$ Literature Professor Matthiessen (1902-1950) was a sponsor of the Leftist Cultural and Scientific Conference for World Peace, and a teacher at the Salzburg Seminar. In 1950 Matthiessen committed suicide, leaving a note saying, "How much the state of the world has to do with my state of mind, I do not know [He was a closeted and depressed gay man]. But as a Christian and a Socialist, believing in international peace, I find myself terribly oppressed by the present tensions."

${ }^{3}$ According to Fox, geography, especially the use of oceanic or fluvial communication, largely determines the political type of a society and its degree of openness. While Europe and the U.S. were bound to become closest economic partners, Russia, as a huge landlocked country where rivers ran the wrong way, was unlikely to become a de-centralized democracy driven by market-forces.

${ }^{4}$ Henry Morgenthau (1891-1967) was Chair of the New York State Agricultural Advisory Committee (1929-33) and Secretary of the Treasury (193444). In September 1944, he convinced Roosevelt and Churchill to adopt his "Plan for postwar Germany,"calling for this country to be dismembered, partitioned, stripped of all heavy industry (for ever) and institutions of higher learning "for a considerable period of time", and forced to return to an agrarian economy. He was also a leading participant in the Bretton Woods Conference that created the International Monetary Fund and the International Bank for Reconstruction and Development. Morgenthau resigned in mid-1945, his advice being no longer sought by Truman, but he remained a fixture on the political scene. Notably, he was a trustee of the Institue of International Education, along with e.g. Rep. Sen. John F. Dulles and Thomas W. Lamont, a banker and fellow of the Harvard Corporation.

${ }^{5}$ Thomas D. Isern, "William I. Myers and the Modernization of American Agriculture”, The History of Science Society, 2001, p. 433.

6 Jacqueline McGlade, "Confronting the Marshall Plan", The Marshall Plan Today..., p. 187. Officially, Truman asked W. Averell Harriman, Roosevelt's former ambassador to the Soviet Union during WWII and his own Secretary of Commerce, to head a committee to examine "the European relief question".

${ }^{7}$ The Dutch-born Dr. Cornelius Willem de Kiewiet had degrees from London, Paris and Berlin. From 1929 to 1942 he was a professor at the University of lowa, and he became a U. S. citizen in 1939. De Kiewiet came to Cornell in 1941 as a professor of British Colonial History. During WWII, he served as director of Cornell's Army courses in area studies and foreign languages. He was appointed Dean of the College of Arts and Sciences in 1945, Provost in 1948, and served as acting president from 1949 to 1951. According to Bishop, "he enjoyed a considerable unpopularity", and he eventually left Cornell to become President of the University of Rochester (Morris Bishop, A History of Cornell, Cornell University Press, 1962, p. 571 and 593).

${ }^{8}$ In the first draft of this speech, De Kiewiet had written "died". His successor Dr. Deane Malott (1951-63) would go for the Romans, whose "Empire fell, not by the force of arms, but by the spiritual collapse of her people" (Commencement Address, 1951). There is nothing new in the neo-conservative rhetoric. Malott also used to speak of "the pressure we are constantly under to try to match Russia in the war of science".

${ }^{9}$ Since 1948 the Chairman was Arthur H. Dean, a partner in the New York law firm of Sullivan and Cromwell, and the chief counsel to the Standard Oil Company of New Jersey (now Exxon Mobil). In 1953, at the behest of Mr. Dulles, Dean's old law firm mentor and current Secretary of State, he was appointed a Special Deputy Secretary of State to handle the preliminary Korean War Armistice negotiations at Panmunjom.

${ }^{20}$ De Kiewiet Papers, \# 3-7-2559-10. Division of Rare and Manuscript Collection, Cornell University Library.

${ }^{21}$ The European Defense Community was proposed in 1950 by French Premier René Pleven. It was to include West Germany, France, Italy and the Benelux countries. Denounced by many as a threat against national sovereignty, it failed to obtain ratification in the French Parliament, with Gaullists, Communists, and old-school Radicaux-Socialistes like Herriot and Daladier joining in opposition (1954).

${ }^{22}$ Harry Bayard Price, The Marshall Plan and its Meaning, Cornell UP, 1955.

${ }^{23}$ That scholarship was endangered by McCarthyism was emphasized by diplomat and historian George F. Kennan in his speech for Radcliffe College Commencement Address in August 1954: "We have seen... our scholars encouraged to be cautious and unimaginative in order to escape being controversial."

${ }^{24}$ Michael H. Ullmann, "Caught in a Crossfire: Deane Malott and Cornell during the McCarthy Era," senior thesis, Cornell, 1980, and Carol Kammen, Glorious to view: Cornell, Cornell UP, 2003, p. 148-52. The Cornell administration's position appeared clearly when two professors, Philip Morrison, Physics, and Marcus Singer, Zoology, were investigated by Congress for Communist affiliations in their youth.

${ }^{25}$ Nettels Papers, \# 14-17-1256, box 1. Division of Rare and Manuscript Collection, Cornell University Library.

${ }^{26}$ Operation Paperclip: German scientists and the Cold War, New York: Atheneum, 1971, p. 209-10.

${ }^{27}$ Krige, American Hegemony and the Postwar Reconstruction of Science in Europe, MIT Press, Cambridge, MA, 2006, note 120. On Morrison, cf. our note 25.

${ }^{28}$ Peter M. Blau, "Orientation of College Students toward International Relations," The American Journal of Sociology, 1953, p. 213. The issue contains a survey conducted by Rose Goldsen and other Cornell sociologists on several campuses about students' views about international cooperation, the image of Germany, etc.

${ }^{29}$ De Kiewiet Papers, \#, 3-7-2559, box 8. Division of Rare and Manuscript Collection, Cornell University Library. Letter from Dr. Stoddard, April $24,1950$.

${ }^{30}$ Prof. Shane Hamilton is working on a book entitled "Supermarket USA: Food and Power in the American Century." The first French supermarket appeared in 1949 (Landerneau, Brittany), the first British supermarket in 1951 (Earl's Court, London).

${ }^{31}$ Alice C. Evans Papers, \#2552, box 1. Division of Rare and Manuscript Collection, Cornell University Library: “Dear Doctor Evans, My friend Dr. Wagner from Praha/ Czechoslovakia told me that I can get some information [from you]... I am here to see and collect some teaching material for our college in Praha, etc."

${ }^{32}$ Michael L. Dolfman and Solidelle F. Wasser, Monthly Labor Review , 2005.

${ }^{33}$ The most famous was Professor Alice Cook. An Education director for the Philadelphia Joint Board of the United Textile Workers during WWII, Cook was sent in 1945 by the U.S. Military Government on several missions in Germany, in order to assess the needs of the German labor movement for worker education programs. Her then-husband was labor attaché under the Marshall Plan. She later worked in Vienna, Austria, and then joined the Cornell Faculty in 1952. The Alice Cook House is named after her. Marcia L. Greenbaum, "Alice Cook: Lifelong Scholar, Consummate Teacher", The ILR School at Fifty, Cornell, 1996, p. 48.

${ }^{34}$ W. Duane Evans Collection, \#3091, Kheel Center, Cornell University Library.

${ }^{35}$ The Economic Cooperation Agency (ECA) was the agency created to implement the Marshall plan.

${ }^{36}$ Review of "The Fulbright Program: A History (1966), International Review of Education / Internationale Zeitschrift für Erziehungswissenschaft / Revue Internationale de l'Education, 1968, p. 345.

${ }^{37}$ Richards Pells, Not Like Us: How Europeans Have Loved, Hated, and Transformed American Culture Since World War II, New York: Basic Books, 1997, p. 61.

${ }^{38}$ The Foundation had redefined its missions in the late 1920s: thereafter it focused on the promotion of general education and public health, and acted primarily through grants and fellowships. After 1945, the Rockefeller people were "awaited [by European scientists] practically like the Messiah", according to John Krige, American Hegemony..., p. 82. 


\section{Fragile Foundations and Infant Institutions The Case of Non-Reform in Haiti}

Katie Engelhart

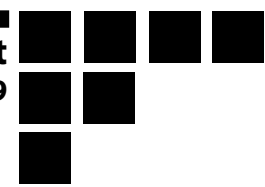

Haiti has earned the dubious distinction of being one of the poorest nations, on a per capita basis, in the world. Even the country's relatively recent transition from authoritarianism to democratic rule was not enough to spark liberal-market reform and the country's integration into the global economy. The Haitian people have thus been confined to decades of deprivation, under a variety of regimes that span the political spectrum.

Despite the rapid series of regime changes that have occurred in Haiti over the past twenty five years, fundamental shifts in the nature of the state have not materialized. Haiti is essentially a case of economic non-reform; it has failed to undergo neoliberal reforms and become integrated in the global market. As the country moves away from dictatorship and through a series of democratically elected governments, it becomes increasingly evident that the nature of the country's economic program is not dependent on ideology. Neither dictator nor elected president has been able to modernize Haiti's devastatingly backwards economy. Instead, economic programs are designed in a context of pervasive political instability; their character is therefore dictated largely by pragmatism and a need to 'crisis manage'.

Regime type in Haiti is inconsequential; what determines whether neoliberal reform is initiated is regime stability. This decisive element is, in turn, dependent on a host of factors, from institutional strength, to the nature and extent of international involvement.

\section{Introduction}

Since the fall of the Duvalier dictatorship, Haiti has witnessed a rapid succession of political leaders. After Francois Duvalier won the presidency in 1957, his rule quickly degenerated into a brutal dictatorship.
Duvalier and his son would rule Haiti by authoritarian decree for a combined twentynine years, their command ending in February 1986. It was only in 1990 that Jean-Betrand Aristide became Haiti's first democratically elected President, with Rene Preval as his Prime Minister. But even this elected government was only able to serve seven months in office, before being overthrown in a coup and replaced by a military-backed regime that ruled for four years before Aristide was reinstated.' The constitution forbids consecutive terms, but allows for reelection. ${ }^{2}$ For this reason, power over the past decade has thus been passed between Aristide, Preval and a number of transitional governments. ${ }^{3}$ After Aristide failed to serve out his third term, Rene Preval was re-elected on February 7, 2006.

Two characteristics define the Haitian economy. One is its lack of real growth over the past half century; the other is the lack of correlation between the regime in power and the nature of the economic program. Haiti is one of the poorest countries, on a per capita basis, in the Western Hemisphere. While real growth in GDP averaged $5.2 \%$ in the years following Duvalier's dictatorship, it fell to $2.9 \%$ in 1996, and has since dropped to less than $1 \% .{ }^{4}$ The transition from military rule to democratic governance has not witnessed a simultaneous growth in the economy; Haiti is poorer in real terms today than it was in 
1955, before Duvalier assumed control. ${ }^{5}$ It faces not just stagnation, but actual decline. According to Robert Fatton Jr., "Haiti still hovers on the verge of political catastrophe; it faces economic ruin." 6 Moreover, the system of rapidly changing regimes further works against neoliberal reform by preventing any type of coordinated strategy for reform from being implemented.

\section{The (Non)relationship between Regime Type and Economic Strategy}

Pervasive economic stagnation, and in some cases real decline, has occurred alongside great oscillations in political character. Manufacturing's contribution to GDP is now less than half of what it was under the militarybacked regime of 1991. ${ }^{7}$ However, this decline in the manufacturing sector did not occur instantaneously when Haiti transitioned to democracy; rather, economic decline in real terms has been a gradual process. Even within the context of democratic rule, GNI per capita has decreased drastically from \$1464 in 2002 to $\$ 400$ in $2006 .{ }^{8}$

The modest level of integration into the world economy has at best remained constant over time. Despite its membership in the United Nations, "Haiti has avoided close ties with its neighboring countries... [and has distanced] itself from moves toward Caribbean economic and political integration." ${ }^{\prime 9}$ According to Alonso and Hicks, international trade contributed more to Haiti's GDP under the military-backed regime of 1991 (18.3\%) than it did under Preval in 2000 (14.0\%). ${ }^{10}$

With respect to the nature of the economic program, there is no apparent correspondence between authoritarianism and state intervention, or alternatively, between democracy and the goal of freemarket reform. Jean-Claude Duvalier, the second Duvalier dictator, embraced a "relatively 'open' technocratic project." Unlike his father, he promised "economic revolution;" his limited efforts towards liberalization in the 1970s allowed for modest integration into the global economy and additionally contributed to a resurgence of civil society. ${ }^{11}$ In contrast, Aristide, the first president to be elected under free-and-fair elections, released "multiple condemnations [against] imperialist and capitalist exploitation" and denounced [the World Bank and the IMF] "as vile capitalist instruments sucking Haiti's blood."12 Thus, in Haiti, there is no defining relationship between regime type and economic strategy. Rather, the process is astonishingly capricious; leaders have the political autonomy to embrace or reject neoliberal reform according to their own whim.

Economic policy in Haiti is dictated by a need for pragmatism, rather than by ideology. For example, Fatton Jr. argues that despite his radical socialist rhetoric, Aristide committed himself to a fairly moderate economic program. He had few alternatives. Recognizing the need to maintain relations with the 'nationalist bourgeoisie', to court international investment, and to coexist with international organizations, "Aristide acquiesced to a program of structural adjustment designed by the World Bank and the International Monetary Fund ... He espoused strict fiscal austerity, an anticorruption drive, and the modernization of public enterprise. These economic reforms achieved significant success and gained massive international support."13 Thus, limited neoliberal reform was finally embraced in Haiti only because the international and domestic systems demanded it.

\section{The Context: Political and Social Volatility}

Stability on the streets has remained tenuous, and violence continues to threaten governability. "Near anarchy... reigned for two years after President Jean-Betrand Aristide was ousted in 2004" and the police force essentially collapsed. In 2006, it was expected to take up to three years for a new police force to reach the minimum required strength of 20,000. President Preval has therefore requested that the UN Peacekeeping mission to Haiti be extended. ${ }^{14}$ 
In 2004, local militia groups took control of provincial capitals, forcing the Organization of American States to call upon the assistance of UN troops. ${ }^{15}$ In 2005 and 2006, urban violence in Port-au-Prince interfered with preparations for elections. ${ }^{16}$

Amidst this violence, governments are faced with a situation in which they must 'crises manage,' rather than rule. According to Alex Dupuy, the sole task of the provisional government, which took over prior to Preval's reelection in 2006, was "to pacify the country... and this basically meant cracking down on Aristide supporters." Rather than dedicating itself to reform, the administration was limited to pursuing a 'scorched-earth strategy,' which involved rounding up and arbitrarily arresting prominent Aristide party officials. ${ }^{17}$ Einsiedel and Malone further assert that this policy of 'crises management' has been reflected in the nature of UN involvement in Haiti; while the UN previously was involved in a broad range of activities, its efforts have subsequently been "reduced to a small international police force aimed at building a domestic police capacity."18 The UN, subject to the same restrictions as the domestic government, must too limit its role to policing.

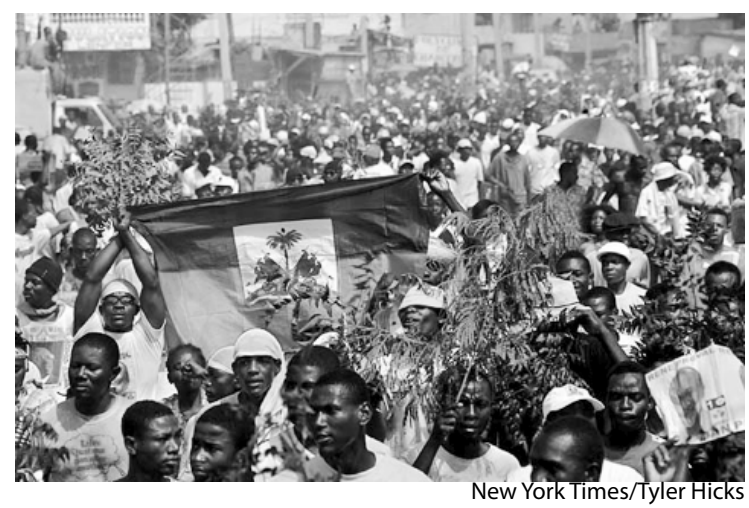

What limits Haiti's capacity to reform the economy is not the type of regime in power, but rather this overwhelming instability. Ruling classes have no vision beyond the day-to-day struggle of maintaining power.
Lacking a coherent ideology and national strategy, their decision-making never includes longer-term considerations. Amidst this "institutionalization of uncertainty," governments can do nothing more than act as policing bodies. ${ }^{19}$ According to Assistant Secretary General Albert Ramdin of the OAS, "the real challenge starts now in terms of maintaining an environment of peace, security, and stability; of encouragement and constructive engagement; and of creating a climate that is conducive to social and economic development and the strengthening and modernization of the state." $^{20}$

\section{Fragile Foundations}

The weakness of political institutions and the lack of an autonomous civil society prevent both governments and non-state organizations from effectively challenging state power. Unable to act as an authoritative counterbalance to state control, these groups are incapable of influencing the policymaking process and spurring the adoption of neoliberal reform.

\section{Haiti's Infant Institutions}

Even if effective economic strategies were developed, Haiti's weak institutional foundation would prevent its implementation. According to Robert Fatton Jr., Haiti is plagued by a lingering authoritarian legacy. While democratization eliminated "the most flagrant tyrannical aspects" of the old regime, the current administration is still built upon the foundations of authoritarianism. ${ }^{21}$ As a result, the constitution has produced an immobilism that continues to favor the status quo and act as an obstacle to reform. Thus, weak institutions have made the government incapable of ruling. Importantly, the current institutional weakness is a political remnant of authoritarianism; weak institutions similarly limited economic reform under dictatorship and under democracy.

As well as limiting the government's 
capacity to reform, weak institutions allow for the concentration of power in the hands of select political leaders who tend to benefit from, and thus work to sustain, the closed economy. Even half a century after the end of Duvalier's rule, total power remains in the hands of a small executive. Weak institutions allow for self-indulgent leaders who have no interest in nurturing autonomous economic actors. This fact was made evident by President Preval's decision on Januray 12, 1999 to declare the National Assembly's term in office expired and to rule by decree. According to Fatton Jr., Haiti's institutional system makes the country a victim of la politique du ventre (politics of the belly); under this system of governance, "politics[becomes] an entrepreneurial vocation... controlling the state becomes a zero-sum game, a fight to the death to monopolize the sinecures of political power."22

Since the power of political leaders is unchecked, and since politics has become virtually the only means of material advancement, leaders resist demands to open up the Haitian economy to international pressures. Rather, they work to maintain a closed system which they can more easily exploit. ${ }^{23}$ Evidence of rent-seeking behavior is widespread. Consistently high levels of corruption suggest that change will not soon be readily implemented from above. Haiti ranked last on the 2004 Transparency International Corruption Index. ${ }^{24}$ Weak institutions have allowed decades of interestmaximizing leaders, of both authoritarian and democratic backgrounds, to hold back neoliberal reform.

A third consequence of weak institutional structure is that it has made the political costs of economic reform too high for political leaders, regardless of their ideology or intention. According to Kapur and Naim, neoliberal reform and structural adjustment "may require policy changes with enormous short-term political costs." 25 Haiti has failed to institutionalize "political society as a means to help mediate conflict and help minimize political deadlock." Thus, these grave shortterm political costs, rather than being tolerated, will more likely lead to the overthrow of the regime which tried to enact them. ${ }^{26}$ Structural adjustment proves to be a large source of urban discontent and polarization. Under these conditions of uncertainty and instability, new governments will be likely to retreat completely from the process of economic reform. Fearful for their own political stability, leaders will reject reform despite inflationary pressures. $^{27}$

An unstable governmental structure permits political infighting to yield not compromise, but stagnation. The clearest example of this political stagnation is the 1997 leadership succession conflict. In 1997, Prime Minister Rosny Smarth resigned in protest over the outcomes of the senatorial elections. Following his recognition, the parliament refused to approve any of Preval's appointments for a successor and the country was left with no Prime Minister for two years. Preval was forced to rule by decree and to implement only the most basic policies. ${ }^{28}$ Political stalemate ensued because state authorities were incapable of forming a functioning government. In the context of an institutional system that does not guarantee a working political body, internal conflicts render governments unable to enact meaningful, long-term reform.

Haiti's weak party structure, marked by intense party conflict and loosely bound coalitions, has created a political environment in which parties are focused desperately on consolidating power; the cause of neoliberal reform is thus marginalized. Political parties were outlawed in the first six years of the Duvalier dictatorship. Though the number of parties has blossomed since the transition to democracy, the parties have failed to become an influential political force. ${ }^{29}$ "Dramatic voltesface reflecting very sudden changes of allegiance are common among the political class." ${ }^{\prime 30}$ This lack of party allegiance creates 
problems for governability; the government is limited in its capacity to enact any type of reform, much less destabilizing neoliberal reforms. Moreover, due to the extensive concentration of power in the hands of the executive, as permitted by the 1987 constitution, the opposition is reduced to a broad-based, loosely bound coalition of parties which seek not to compromise, but to block any and all reform proposed by the party in power. For example, the opposition to Aristide united under the politically fragmented Democratic Convergence (DC), and remained unwilling to negotiate any solution to Haiti's economic problems. $^{31}$ Thus, democratization has not facilitated the emergence of powerful political actors committed to economic reform.

\section{Haiti's Bounded Civil Society}

Economic scarcity has yielded a fragile working class base which is unable to mobilize on the grounds of self-interest and push for economic reform from below. According to Fatton Jr., "Material scarcity had certain perverse advantages for the continuity of dictatorship." ${ }^{32}$ Democratization has not led to the formation of a strong working class; instead, extremely high levels of poverty have "produced a bourgeoisie and a working class that are both, at best, utterly small, embryonic, and fragile." Currently, the working class represents only 9 percent of the labor force, and this number was consistently lower in the past. ${ }^{33}$ The absence of a strong working class eases the pressure on the government to enact the neoliberal reforms which are so crucial to Haiti's long-term economic growth. Fatton Jr. warns that unless civil society can generate an effective political strategy from below, a process of "redictatorialization" may occur. $^{34}$

Institutional weakness is finally evident in the business community's lack of autonomous power. In Haiti, the business community has been tied organically to the state since the Duvalier dictatorship. As a result of the executive's power, "if it wants to continue to do business and/or move into new ventures, the possessing class, more often than not, has to buy 'protection' from the ruling class." ${ }^{13}$ Under a persisting system of crony-capitalism, favors are doled out by the government to preferred businesses and the stability of the business community is inextricably linked to government interests. Unity between the government and the business class "is rooted in an opportunistic convergence of interests." ${ }^{16}$ This organic link to the state prevents the business community from taking action to bring about neoliberal reform; its interests are more effectively served by acquiescing to the wishes of the government in power. Moreover, the system of crony capitalism works to advance friends of the political elite, not the best interest of the national economy. ${ }^{37}$

Persisting social instability suggests that Haiti will not have the necessary institutional foundation to pursue neoliberal reform in the near future. Von Einsiedel and Malone argue that a fundamental challenge to the construction of strong, democratic institutions is Haiti's lack of human capital. Eighty percent of Haitians with college degrees live out of the country and "the lack of skilled Haitians to build up state institutions presents a severe development challenge." ${ }^{\prime 38}$ According to Alex Dupuy, President Rene Preval faces "the classic contradictions of the populist politician. In a country in which 80 percent of the population is unemployed and annual per capita income is less than US\$400, Preval realizes that the people who voted for him expect him to prioritize their need for access to jobs, food, health care, housing, education, and security." ${ }^{\prime 39}$ The need for neoliberal reform will thus continue to appear secondary.

\section{The Guiding Hand: Foreign Influence and Involvement}

According to Fatton Jr., Haiti is shaped by a myriad of external forces, which confine the country to complete dependence. ${ }^{40}$ "External factors remain decisive and in some 
instances determine the shape of Haitian politics, for the country's material well-being is utterly dependent on the whims of the world economy and the demands of foreign financial organizations." ${ }^{\prime 1} \quad$ Because of the country's material dependence, Haiti's economic program is in large part dictated by the extent and character of international, and specifically American, involvement. International structural conditions remove Haiti's economic agency.

United States policy is responsible for the modest opening up that has occurred in Haiti in the past few decades; this American policy is independent of the specific regime in power in Haiti. The United States continues to push for liberal-market societies within its'zone of influence.' In limited cases, this concerted American effort has led to modest progress in the move towards neoliberalism. ${ }^{42}$ American involvement with the Duvalier dictatorship illustrates clearly how Haitian economic strategy is entangled with that of the United States. In mid-1977, Duvalier began to yield to American pressure to ameliorate certain aspects of its economic policy. In November 1979, in return for increased American aid and under pressure from President Jimmy Carter, Duvalier ordered a series of ministerial and budgetary reforms and hesitantly accepted limited economic liberalization. ${ }^{43}$

American involvement with Aristide mirrored its involvement under Duvalier. The U.S. presence in Haiti acted in opposition to the Haitian administration, in an attempt to liberalize the economy. American influence over Aristide would yield two main results. First, "once in power, Aristide... was forced to adopt extremely pragmatic economic policies that never went beyond the World Bank's vision of 'basic needs."' Thus, American influence dictated the nature and extent of economic reform. Second, "the American intervention opened up a limited political space to struggle for a more equitable pattern of economic development." ${ }^{14}$ American involvement thus forced the Haitian administration to open up at least minimally to pressure from below. American goals for Haiti have remained steadfast over time, as has the unwillingness of Haitiangovernments toenactneoliberal reform from above. Thus, the effect of this American involvement has remained consistently modest. Furthermore, the ideology driving American efforts has little to do with the specifics of the regime in power in Haiti and more to do with domestic factors within the United States. As Smith argues, American "domestic politics became the driving force behind U.S. policy." 45 Thus, international structural conditions, which allow for the primacy of American interests, have largely dictated levels of neoliberal reform.

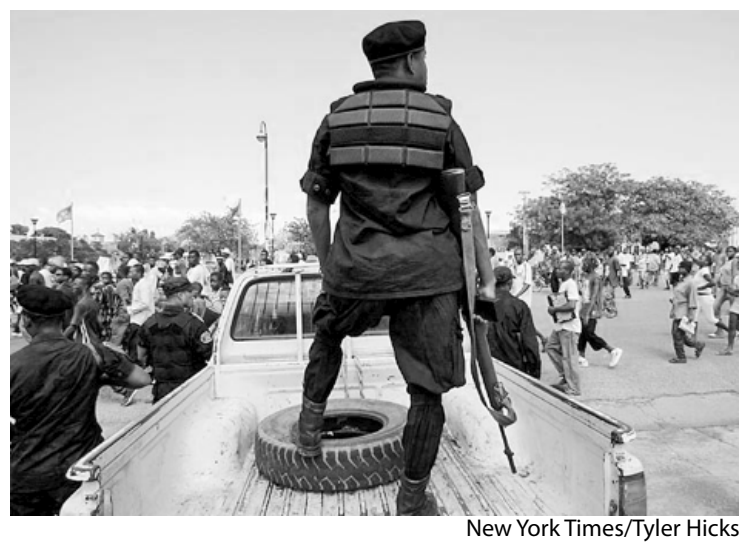

Despite some limited success in opening the Haitian economy, international involvement has had some unintended negative consequences, one of which is the weakening of the Haitian state. This weakening is brought about first by international pressure from global superpowers. According to Fatton Jr., increasing international pressure means that "Preval seems condemned to adopt a structural adjustment program even if it may generate more inequalities and popular discontent." $^{\text {46 }}$ Thus, when superpower interests contrast those of the Haitian state, the Haitian state is subjugated and weakened. Second, the weakening is brought about by international donor agencies. According to Kapur and Naim, "size matters!" In very poor 
countries like Haiti, law-based democratic governance faces many obstacles. When the IMP becomes involved, its dominance vis-à-vis Haiti is asymmetric; the Haitian government is thus marginalized in the process of policy formation. ${ }^{47}$ This weakening of the state could perversely affect the very neoliberal reform which the international community seeks to bring about.

Secondly, a reliance on foreign aid sources short-circuits the process of neoliberal reform. International organizations have transformed Haiti into "the Republique des Organisations Nongouvernementales (ONGs)", or, the Republic of NGOs. ${ }^{48}$ Reliance on aid has prevented governments from facing economic crisis; thus, governments have not been forced to diversity the economy and to encourage export-oriented growth. Much of the annual budget is still derived from foreign aid. ${ }^{49}$ However, this economic security, dependent so heavily on the sentiments of international agencies, is fragile. Furthermore, short-term aid may directly crowd out long-term business investment or, indirectly prevent the creation of viable financial institutions through which investment could be channeled. Currently Haiti's dependence on aid shows no sign of being severed by the international community; on July 25, 2006, at a conference in Port-auPrince, donor nations pledged approximately $\$ 750$ million in new aid for Haiti. ${ }^{50}$

\section{Conclusion}

According to Kurt Weyland, Latin American countries have been able to successfully enact neoliberalism "when they faced dramatic crises, and the population was therefore prepared to swallow the bitter pill of tough stabilization." ${ }^{51}$ However, this argument fails in Haiti, where 'dramatic crises' and inflationary pressures have neither encouraged the populace to, at least tacitly, accept the short-term costs of reform, nor provoked governments to open the Haitian economy. Rather, the past decades of instability have created an environment of permanent crisis. In this context, ideology is rendered irrelevant and economic strategy remains independent of the type of regime in power. Political instability, weak institutions and an omnipotent international presence have ultimately prevented both authoritarian and democratic regimes from successfully implementing neoliberalism.

\section{Endnotes}

Arthur S. Banks, et al. eds. Political Handbook of the World 2005-2006. (Washington: CQ Press, 2006), $482-483$.

${ }^{2}$ Alex Dupuy. "Haiti Election 2006: A Pyrrhic Victory for René Préval?" Latin American Perspectives 248 (2006): 133.

${ }^{3}$ Arthur S. Banks, et al. eds. Political Handbook of the World 2005-2006. (Washington: CQ Press, 2006), 483.

${ }^{4}$ Arthur S. Banks, et al. eds. Political Handbook of the World 2005-2006. (Washington: CQ Press, 2006), 482.

5 "Haiti: An Uphill Struggle." Economist 379 (2006).

${ }^{6}$ Robert Fatton Jr.. "The Impairments of Democratization: Haiti in Comparative Perspective." Comparative Politics 31 (1999): 222

${ }^{7}$ Irma Alonso T., ed. Caribbean Economies in the Twenty-First Century. (Gainesville, Florida: University Press of Florida, 2002 ), 55.

${ }^{8}$ "Country Report: Haiti." (2006) <http://www.freedomhouse.org/template.cfm?page=22\&year=2006\&country=6976>

${ }^{9}$ Arthur S. Banks, et al. eds. Political Handbook of the World 2005-2006. (Washington: CQ Press, 2006), 485.

Irma Alonso T., ed. Caribbean Economies in the Twenty-First Century. (Gainesville, Florida: University Press of Florida, 2002 ), 56.

${ }^{2}$ Robert Fatton Jr.. Haiti's Predatory Republic: The Unending Transition to Democracy. (Boulder: Lynne Rienner Publishers, 2002$), 57$.

${ }^{3}$ Robert Fatton Jr. Haiti's Predatory Republic: The Unending Transition to Democracy. (Boulder: Lynne Rienner Publishers, 2002), 79.

${ }^{4}$ Robert Fatton Jr. Haiti's Predatory Republic: The Unending Transition to Democracy. (Boulder: Lynne Rienner Publishers, 2002$), 79$.

5 "Haiti: An Uphill Struggle." Economist 379 (2006).

${ }^{6}$ David M. Malone and Sebastian Von Einsiedel. "Peace and Democracy for Haiti: A UN Mission Impossible?" International Relations 20 (2006): 163.

7 "Country Report: Haiti." (2006) <http://www.freedomhouse.org/template.cfm?page=22\&year=2006\&country=6976>

${ }^{8}$ Alex Dupuy. "Haiti Election 2006: A Pyrrhic Victory for René Préval?" Latin American Perspectives 148 (2006): 132-133.

${ }^{9}$ David M. Malone and Sebastian Von Einsiedel. "Peace and Democracy for Haiti: A UN Mission Impossible?" International Relations 20 (2006): 153.

${ }^{20}$ Robert Fatton Jr. Haiti's Predatory Republic: The Unending Transition to Democracy. (Boulder: Lynne Rienner Publishers, 2002$), 38$.

2 Janelle Conaway. "Help for Haiti." Americas 58 (2006).

22 Robert Fatton Jr. "The Impairments of Democratization: Haiti in Comparative Perspective." Comparative Politics 31 (1999): 209.

${ }^{23}$ Robert Fatton Jr. Haiti's Predatory Republic: The Unending Transition to Democracy. (Boulder: Lynne Rienner Publishers, 2002), xi.

${ }^{24}$ David M. Malone and Sebastian Von Einsiedel. "Peace and Democracy for Haiti: A UN Mission Impossible?" International Relations 20 (2006): 154.

${ }^{25}$ David M. Malone and Sebastian Von Einsiedel. "Peace and Democracy for Haiti: A UN Mission Impossible?" International Relations 20 (2006): 164.

${ }^{26}$ Devesh Kapur and Moises Naim. "The IMF and Democratic Governance." Journal of Democracy 16 (2005): 89.

${ }^{27}$ Robert Fatton Jr. "The Impairments of Democratization: Haiti in Comparative Perspective." Comparative Politics 31 (1999): 221.

${ }^{28}$ Arthur S. Banks, et al. eds. Political Handbook of the World 2005-2006. (Washington: CQ Press, 2006), 482. 
${ }^{29}$ David M. Malone and Sebastian Von Einsiedel. "Peace and Democracy for Haiti: A UN Mission Impossible?" International Relations 20 (2006): 157158.

${ }^{30}$ Arthur S. Banks, et al. eds. Political Handbook of the World 2005-2006. (Washington: CQ Press, 2006), 486.

${ }^{31}$ Robert Fatton Jr. "The Impairments of Democratization: Haiti in Comparative Perspective." Comparative Politics 31 (1999): 222.

32 "Country Report: Haiti." (2006) < http://www.freedomhouse.org/template.cfm?page=22\&year=2006\&country=6976>

${ }^{33}$ Robert Fatton Jr. "The Impairments of Democratization: Haiti in Comparative Perspective." Comparative Politics 31 (1999): 216.

${ }^{34}$ Robert Fatton Jr. Haiti's Predatory Republic: The Unending Transition to Democracy. (Boulder: Lynne Rienner Publishers, 2002$), 34$.

${ }^{35}$ Robert Fatton Jr. "The Impairments of Democratization: Haiti in Comparative Perspective." Comparative Politics 31 (1999): 218.

${ }^{36}$ Robert Fatton Jr. Haiti's Predatory Republic: The Unending Transition to Democracy. (Boulder: Lynne Rienner Publishers, 2002$), 9$.

${ }^{37}$ Robert Fatton Jr. Haiti's Predatory Republic: The Unending Transition to Democracy. (Boulder: Lynne Rienner Publishers, 2002$), 37$.

${ }^{38}$ Peter Smith. Talons of the Eagle: Dynamics of U.S.-Latin American Relations. Oxford, 2000.

${ }^{39}$ David M. Malone and Sebastian Von Einsiedel. "Peace and Democracy for Haiti: A UN Mission Impossible?" International Relations 20 (2006): 165.

${ }^{40}$ Alex Dupuy. "Haiti Election 2006: A Pyrrhic Victory for René Préval?" Latin American Perspectives 148 (2006): 133.

${ }^{41}$ Robert Fatton Jr. Haiti's Predatory Republic: The Unending Transition to Democracy. (Boulder: Lynne Rienner Publishers, 2002$), 88$.

${ }^{42}$ Robert Fatton Jr. "The Impairments of Democratization: Haiti in Comparative Perspective." Comparative Politics 31 (1999): 218.

${ }^{43}$ Robert Fatton Jr. Haiti's Predatory Republic: The Unending Transition to Democracy. (Boulder: Lynne Rienner Publishers, 2002$), 39$.

${ }^{44}$ Arthur S. Banks, et al. eds. Political Handbook of the World 2005-2006. (Washington: CQ Press, 2006), 483.

${ }^{45}$ Robert Fatton Jr. "The Impairments of Democratization: Haiti in Comparative Perspective." Comparative Politics 31 (1999): $220-222$.

${ }^{46}$ Peter Smith. Talons of the Eagle: Dynamics of U.S.-Latin American Relations. Oxford, 2000.

${ }^{47}$ Robert Fatton Jr. "The Impairments of Democratization: Haiti in Comparative Perspective." Comparative Politics 31 (1999): 222.

${ }^{48}$ Devesh Kapur and Moises Naim. "The IMF and Democratic Governance." Journal of Democracy 16 (2005): 89.

${ }^{49}$ Robert Fatton Jr. Haiti's Predatory Republic: The Unending Transition to Democracy. (Boulder: Lynne Rienner Publishers, 2002$), 29$.

${ }^{50}$ Arthur S. Banks., et al. eds. Political Handbook of the World 2005-2006. (Washington: CQ Press, 2006), 482.

52 Janelle Conaway. "Help for Haiti." Americas 58 (2006).

${ }^{53}$ Kurt Weyland. "Neoliberalism and Democracy in Latin America: A Mixed Record." Latin American Politics and Society 46 (2004): 137.

\section{Works Cited}

Alonso, Irma T., ed. Caribbean Economies in the Twenty-First Century. Gainesville Florida: University Press of Florida, 2002.

Banks, Arthur S., et al. eds. Political Handbook of the World 2005-2006. Washington: CQ Press, 2006.

Conaway, Janelle. "Help for Haiti." Americas. October 2006. Vol. 58, Iss. 5; pg6.

Country Report: Haiti (2006). <http://www.freedomhouse.org/template.cfm?page=22\&year=2006\&country=6976>

Dupuy, Alex. "Haiti Election 2006: A Pyrrhic Victory for René Préval?" Latin American Perspectives. May 2006. Vol.33, Iss. 148, No.3. pp. 132-141.

Erikson, Daniel P., and Adam Minson. "The Caribbean: Democracy Adrift?" Journal of Democracy. October 2005. Vol.16, Iss. 4.

Fatton Jr., Robert. Haiti's Predatory Republic: The Unending Transition to Democracy. Boulder: Lynne Rienner Publishers, 2002. (Fatton Jr. A)

Fatton Jr., Robert. "The Impairments of Democratization: Haiti in Comparative Perspective." Comparative Politics. January 1999. Vol. 31, Iss. 2. pp. 209229. (Fatton Jr. B)

"Haiti: An Uphill Struggle." Economist. February 2006. Vol. 379, Iss. 8483.

Kapur, Devesh and Moises Naim. "The IMF and Democratic Governance." Journal of Democracy. Baltimore: Jan 2005. Vol. 16, Iss. 1.

Malone, David. M., and Sebastian Von Einsiedel. "Peace and Democracy for Haiti: A UN Mission Impossible?" International Relations. 2006. Vol. 20, Iss. 2. pp. 153-217.

Smith, Peter. Talons of the Eagle: Dynamics of U.S.-Latin American Relations. Oxford, 2000.

"The Rubbishing of a Vote." Economist. February 2006. Vol 378, Iss. 8465.

Weyland, Kurt. "Neoliberalism and Democracy in Latin America: A Mixed Record." Latin American Politics and Society. Spring 2004. Vol. 46, Iss. 1. 


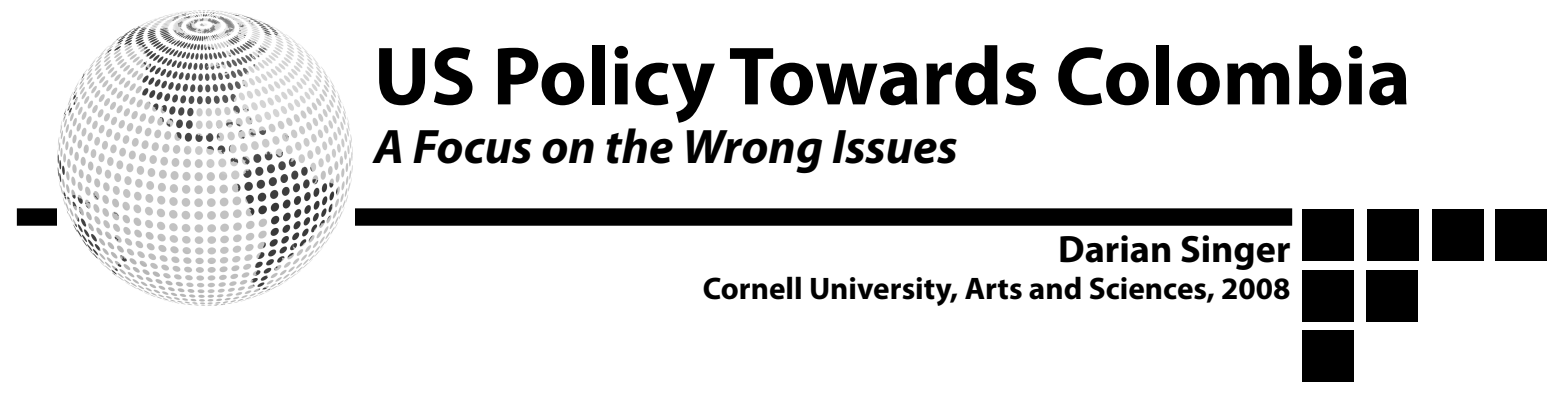

In recent years the United States has undertaken daunting activities in fighting two overarching wars against intangible enemies across many borders. The war on drugs and the war on terror have severed many national ties, even as globalization continues. Only a few countries, however, have experienced the full devastation of both of these wars simultaneously. Colombia has been the epicenter of the war on drugs and is considered a crucial front in the war on terror. The politics within Colombia have been profoundly affected under the constant watch of the United States. Much of the recent policy in Colombia has focused on the wars on drugs and terror to appease America and its leaders. In light of all this effort, little has fundamentally changed. Colombia, though its famous Medellín and Cali drug cartels have fled, remains a haven for coca cultivation and home to many violent paramilitary and guerrilla groups who frequently spread violence throughout the country. The United States has focused heavily on drug politics through the injection of military aid and arms. The biggest fault in this political tactic is that arms only continue to fuel the already-problematic violence across the Colombian countryside. This presents a paradox in American foreign policy that demands the attention of the international community.

Issues of globalization, illicit trades, and violence are extremely important to international politics. Colombia, as one of the oldest democracies in the western hemisphere, plays an important role in the politics of Latin America and the world. Colombia is currently working towards a free trade agreement with the United States as a means of bettering its infrastructure to further combat issues of drugs and violence. Colombia's strategic location, bordering both the Gulf of Mexico and the Pacific Ocean while being close to the Panama Canal, makes its politics important to United States and the western hemisphere. Last, the presence of drugs and arms in the world economy is extremely destructive to the people living in affected areas.

The important problems that Colombia faces have been present in Latin America for a long time, although Colombia's history with drug cultivation, trade, and violence is relatively young. The drug trade started to affect Colombia only in the 1970s as Bolivian and Peruvian traffickers utilized routes in the country for transporting drugs. As a result of counternarcotics efforts in Bolivia and Peru, production within Colombia started to accelerate. By the 1990s, Colombia provided as much as $90 \%$ of the cocaine consumed in the United States as well as a significant portion of heroin. ${ }^{1}$ It was also at this point that the paramilitary groups began to take their current shape, with extensive growth in the 1980s and 1990s. The growth of the paramilitary groups resulted in an expansion of the illicit arms trade, since these organizations were the primary users of such weapons. Due to the growth of both the arms and drug trades in the last two decades of the $20^{\text {th }}$ century, they became increasingly intertwined. This relationship between the two trades is crucial to understanding both the problems of U.S. foreign policy in Colombia and Colombian domestic policy.

Although little research has been done in regards to this relationship, it is still quite strong. For example, Colombia is one of the 
leading recipients of U.S. military aid as a result of efforts to combat drugs. Furthermore, many arms in Latin America enter the illicit markets via legal military transactions followed by illegal sales conducted by military personnel. Colombia is also among the least-active opponents of small arms in its region, leading to fewer restrictions than its neighbors. It is one of the few nations in the Americas to not keep detailed records of holdings, transactions, and transfers of small arms and light weapons as of $2006 .{ }^{2}$ Colombia, with U.S. assistance, has shown equally poor control over the illicit narcotics trade. Even efforts to fumigate coca crops have been unsuccessful in bringing the cultivation back to the levels of the 1980s. ${ }^{3}$ The 2007 International Narcotics Control Strategy Reports (INCSR) from the U.S. Department of State showed significant increases in eradication efforts especially between 2004 and 2006, while drug cultivation rose to 144,000 hectares from 114,000 the year before. ${ }^{4}$ Failed attempts at controlling the trades and continued growth of the trades are commonplace in Colombia.

Colombia's guerrilla and paramilitary groups play an important role in the trades as well and lead to further connections between drugs and arms. The guerilla groups, especially, have experienced massive growth in recent years. The Revolutionary Armed Forces of Colombia (FARC), the largest of the organizations, has expanded from 3,600 members in 1987 to roughly 20,000 on more than 105 fronts, covering over $40 \%$ of the country in 2004. ${ }^{5}$ Their relationship to the drug trade remains somewhat unclear, although it is apparent that even on the most optimistic level, revenue is being made from the coca crops and is further being used to fortify their military machine. It is also fairly clear that the drug trade has added stronger enemies for the FARC and other guerilla groups in the form of the Colombian and United States militaries. The existence of these enemies has increased the need for arms in disputed territories, leading to another tie between drugs and arms. One trend that has also become abundantly clear is the increased quantities of arms purchased by FARC, other guerilla groups, and the United Self-Defense Forces of Colombia (AUC-the primary paramilitary group). Historically, these groups avoided bulk purchases to avoid attention; however, this has begun to change due to increased requirements when fighting the U.S.-supported Colombian forces. ${ }^{6}$ The nonstate actors in Colombia provide an additional set of connections between the cultivation of drugs and the trade in illicit arms.

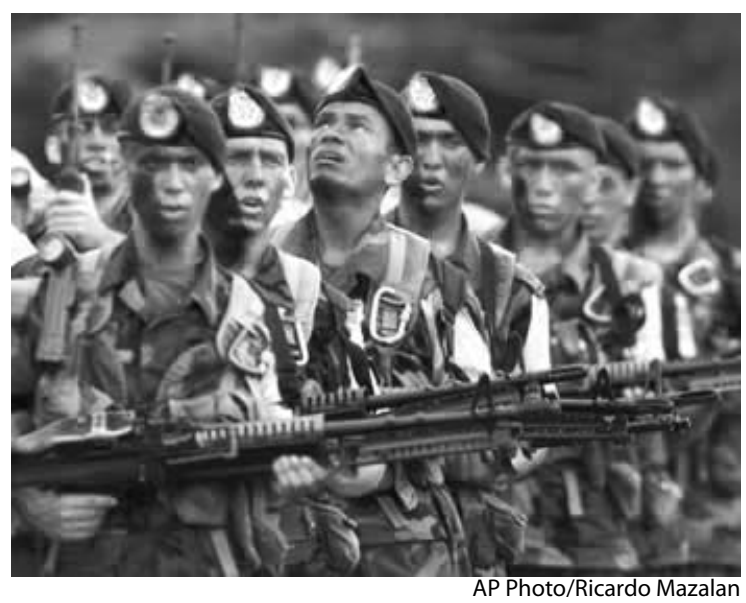

Despite the strong ties between the two trades, the United States, a crucial player in nearly all international relations, has taken some steps towards the eradication of drugs in Colombia while not paying much attention to the issue of arms. Plan Colombia is the embodiment of this narrow focus on narcotics. The initial proposals for the legislation by Colombian President Andrés Pastrana in 1998 called for international aid for a variety of investments in social development as a means of reducing crime and bettering the overall sociopolitical sphere within the country. The primary means for meeting such goals involved the subsidized replacement of crops for small cultivators of coca as well as extensive peace negotiations. However, the legislation quickly became altered by U.S. views to focus on counternarcotics through high levels of military 
aid. This updated policy, which received little media coverage and was not even available in Spanish when first introduced, was approved by the United States Congress with $\$ 860$ million initially dedicated to military aid. ${ }^{7}$ Colombia created and trained a highly-mobile military force meant for counternarcotics across the Colombian countryside. Plan Colombia also called for aerial fumigation of drug crops as an important part of the legislation. The fumigation, which has been occurring since the 1980s (originally for marijuana crops), has failed to reduce the number of crops, and remains dangerous to the farmers exposed to the chemicals. Furthermore, coca cultivation is a highly mobile business often characterized by a 'balloon effect,' in which the elimination of one area of growth results in the creation of another. The United States has continued its financial support for the Colombian counterinsurgency and counternarcotics efforts, although they are quite different from the initial goals put forward by the Colombian government. The efforts of the United States government show its narrow understanding of the issues in Colombia. Legislation has consistently chosen to focus on the issue of drugs while adding arms to the country, which has in turn led to more violence and human rights violations. This is where the paradox in US policy lies.

The situation in Colombia is devastating for those who must live with it day-to-day. The United States, while focusing on its own goals, has used its ability to throw its weight around in such a way that has left the Colombian government with little say in its own domestic politics. The focus on counternarcotics through a series of military endeavors has done little to solve the sociopolitical problems and has in fact increased other harms, such as the violence caused by armed conflicts. The reasons for such a counterproductive set of policy goals remain unclear, but must be acknowledged.

Though many possible policies could be beneficial to the Colombian situation, the most successful are likely to come in the form of social policies. Alternative development is likely to be the best policy to help Colombia. This policy calls for viable options outside of the narcotics industry for farmers and individuals who have had few other possibilities in the past. Attempts so far have not been overarching or permanent enough. Examples include short-term construction, and manufacturing that has had little demand for the products. Alternative development must create long-term jobs, be involved in a growing inudstry, and be properly financed.

Alternative development could also be beneficial to the other problems that plague Colombia. In the case of arms, alternative developmentwould provideworktoindividuals who previously required arms for protection in the drug industry. Furthermore, the switch to other forms of work is likely to severely curb narcotics cultivation and therefore reduce the ability of insurgent groups to purchase arms. Alternative development, however, is not likely to be the sole solution to Colombia's problems.

Peace negotiations should be paired with these alternative development policies. They too are likely to help multiple facets of the Colombian problems. While directly opening up discussion for the insurgent groups, hopefully leading to lessened violence, they should also assist the arms situation. The reduced focus on military action would slow the interior arms race that has been occurring throughout the country. Peace negotiations with U.S.-support would likely grant needed authority to the Colombian government as well, therefore strengthening the country's institutions. Peace negotiations have been attempted in the past, but without proper support domestically and internationally, they have not been successful.

The situation in Colombia is extremely complex, and there is no set of solutions that will solve every problem. However, alternative development, peace negotiations, and most importantly a reduction of the focus on 


\section{Endnotes}

'Maria Clemencia Ramirez Lemus, Kimberly Stanton, and John Walsh, Colombia: A Vicious Circle of Drugs and War, Drugs and Democracy in Latin America (Boulder: Lynne Reinner Publishers, 2005), 99.

2 Biting the Bullet, "Reviewing Action on Small Arms 2006: Assessing the First Five Years of the UN Programme of Action by Biting the Bullet" (London: Biting the Bullet, 2006), 58-59.

${ }^{3}$ Maria Clemencia Ramirez Lemus, Kimberly Stanton, and John Walsh, Colombia: A Vicious Circle of Drugs and War, Drugs and Democracy in Latin America (Boulder: Lynne Reinner Publishers, 2005), 115.

${ }^{4}$ Bureau of International Narcotics and Law Enforcement Affairs, "2007 International Narcotics Control Strategy Report," U.S. Department of State, http://www.state.gov/p/inl/rls/nrcrpt/2007/vol1/html/80855.htm.

${ }^{5}$ Mario A. Murillo, Colombia and the United States: War, Unrest and Destabilization (New York: Seven Stories Press, 2004), 70.

${ }^{6}$ Kim Cragin and Bruce Hoffman, Arms Trafficking and Colombia (Pittsburgh: RAND, 2003), 20.

${ }^{7}$ Maria Clemencia Ramirez Lemus, Kimberly Stanton, and John Walsh, Colombia: A Vicious Circle of Drugs and War, Drugs and Democracy in Latin America (Boulder: Lynne Reinner Publishers, 2005), 108.

${ }^{8}$ Committee on Foreign Affairs House of Representatives, "Hearing Before the Subcommittee on the Western Hemisphere of the Committee on Foreign Affairs House of Representatives One Hundred Tenth Congress First Session: US-Colombia Relations" (Washington: US Government Printing Office, 2007), 5.

\section{Works Cited}

Biting the Bullet. "Reviewing Action on Small Arms 2006: Assessing the First Five Years of the UN Programme of Action by Biting the Bullet." Assessment of UN Policy, London: Biting the Bullet, 2006.

Bureau of International Narcotics and Law Enforcement Affairs. "2007 International Narcotics Control Strategy Report." U.S. Department of State. March 1, 2007. http://www.state.gov/p/inl/rls/nrcrpt/2007/vol1/html/80855.htm (accessed February 28, 2008).

Committee on Foreign Affairs House of Representatives. "Hearing Before the Subcommittee on the Western Hemisphere of the Committee on Foreign Affairs House of Representatives One Hundred Tenth Congress First Session." US-Colombia Relations. Washington: US Government Printing Office, 2007. 1-118.

Cragin, Kim, and Bruce Hoffman. Arms Trafficking and Colombia. Defense Intelligence Agency Report, Pittsburgh: RAND, 2003.

Lemus, Maria Clemencia Ramirez, Kimberly Stanton, and John Walsh. "Colombia: A Vicious Circle of Drugs and War." In Drugs and Democracy in Latin America, by Coletta A. Youngers and Eileen Rosin, 99-142. Boulder: Lynne Reinner Publishers, 2005.

Murillo, Mario A. Colombia and the United States: War, Unrest and Destabilization. New York: Seven Stories Press, 2004. 


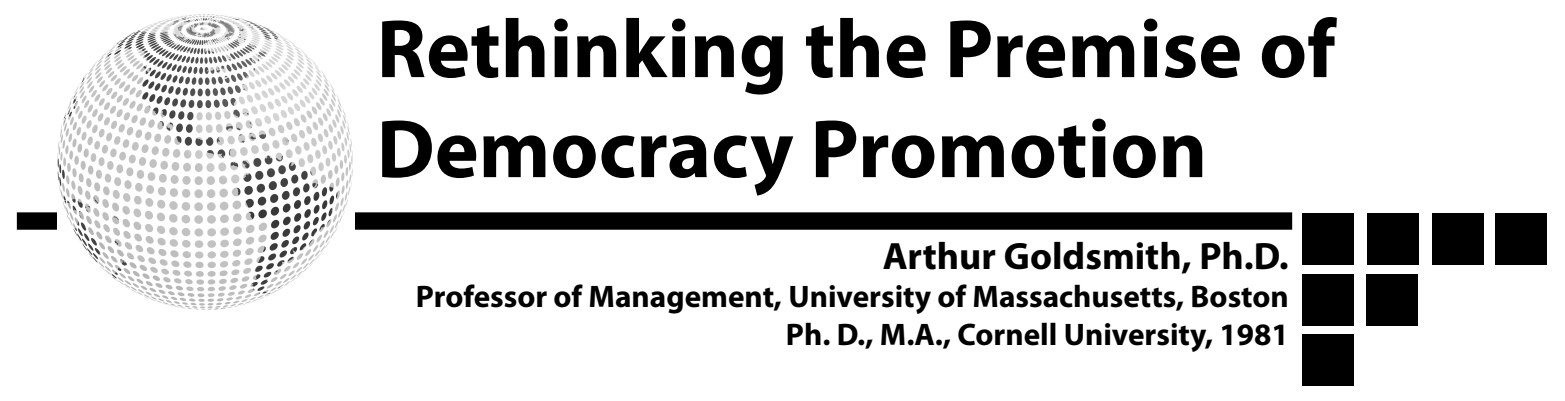

U.S. foreign policy exemplifies a broad Wilsonian consensus about the value of democracy promotion. The "forward strategy of freedom," for example, has been the cornerstone of the Bush administration's geopolitics, but it was not very many years earlier that President Clinton committed the United States to a policy of "democratic enlargement" aimed at growing the number of democracies in the world. Both Senators Barack Obama and John McCain were sponsors of the ADVANCE Democracy Act of 2005. Even after the debacle in Iraq, there is little dissent from the idea that the United States should work to foster a less autocratic world, which, in turn, is understood to lead to less anti-Americanism and diminished threats to U.S. interests. The principal target of these efforts in recent years has been the Greater Middle East, that broad band of Muslim-majority nations that stretches from West Africa to Southeast Asia.

This essay calls attention to a major error in reasoning and evidence that is rarely considered in the Wilsonian consensus. It is a fallacy of division: If democracy is a good thing for international security most observers assume that therefore "every step toward freedom the world makes our country safer," to quotePresidentBush. 'Butresearchconsistently shows that partial steps toward democratic regimes actually multiply the security threats. The encouragement of democracy will never be effective unless its proponents carefully examine the assumptions they make about the undifferentiated benefit of incremental political reforms, and tailor their strategies accordingly.

The intellectual foundation for encouraging democratization is the theory of "democratic peace." Note that it is not the theory of "semi-democratic peace." The theory points to two well-established empirical relationships: Democratic political systems seldom or never fight wars against each other; and (more controversially) democracies have a greater propensity to avoid serious disputes with other countries that could boil over to war. However, these empirical regularities do not apply to countries that mix major elements of undemocratic and democratic practice.

A good example of one of these hybrid regimes from the Muslim world is the Islamic Republic of Iran. It is a religious state that abridges the freedom of worship and does not allow people to speak and write freely. Yet, within the bounds set by spiritual leaders there is lively political participation and vigorous competition for office. Another mixed regime Muslim-majority country is Nigeria. It had a competitive national election with an opposition victory in 1999, but subsequent contests in 2003 and 2007 were marred by violence and charges of fraud and other voting irregularities. Political corruption continues to be a very serious problem in Nigeria and there have been a number of high profile political assassinations. Both of these countries have taken "steps toward freedom," in Bush's phrase, but they are a long way from having reliable and consistent democratic institutions.

How many semi-democratic systems are there? For a reasonably precise answer we can to turn to the Polity data series, which is a source for national regime typologies used widely in political science research. ${ }^{2}$ Of particular utility is the polity2 variable, a composite index for autocracy/democracy that is measured on a 21-point scale ranging 
from minus ten to plus ten. The maximum score would be given to a country in which the executive is chosen in free and fair elections with universal suffrage and where there are substantial checks and balances constraining the chief executive's power. Lower scores reflect diminishing constraints on executive powers and lessening degrees of competitiveness and political participation. Over the past three decades, the average country's polity2 score has risen by five points, indicating a substantial rise in average democratization around the world. But only some countries went over the threshold to become institutionally consistent democratic systems represented at the high end of the polity2 scale; many others became less autocratic but not dependably democratic with open electoral competition and constitutional protections.

To determine the number of mixed regimes versus more purely democratic or authoritarian political systems, I follow the conventional coding system researchers use to sort nations into three groups: A country is classified as fully democratic if its polity2 score is greater than six, and autocratic if polity 2 is less than minus six. Countries with in-between scores are categorized as semidemocratic. As of 2004, the latest year in the Polity IV time series, the world contained seventy-four full democracies, twenty-two autocracies, and fifty-seven semi-democratic systems, according to this coding system. That is a three-fold increase in full democracies and a two-thirds drop in autocracies since 1970but also a doubling in the number of semidemocracies over a thirty-five year period.

Sometimes semi-democracy is a necessary but brief transitory stage before emergence of a rule-bound competitive political system, but that is not the typical pattern in Muslim-majority countries. Far more common is for them to settle into a long-term condition between autocracy and constitutional democracy. To get a better idea of how long these periods can last, I identify regime changes in the 1970s, 1980s, and 1990s, using Polity IV codes and the tripartite division of regime types just mentioned. This allows me to estimate six distinct transitions: Autocracy to partial democracy, partial democracy to full democracy, and autocracy to full democracy, as well as the reverse of each. I define a transition as a shift in regime category that lasts five years or more, and which puts the country in a different category than it was in during the nearest previous episode that also lasted a minimum of five years. The five-year cut-off is based on the assumption that the national leadership will usually be replaced or renewed within that time, giving some assurance that a regime lasting that long has established itself and been stabilized. Regime interludes under five years are not counted as transitions. Since the Polity IV database extends to 2004, the most recent regime changes that can be recorded using this methodology took place in 2000. To gain some historical perspective and have a reasonable sample of cases, I take 1970 as the base year for tabulating transitions (meaning I go back to 1965 to start grouping political systems using the five-year survival rule).

During the three decades beginning in 1970, the world witnessed 116 regime changes as defined above, with thirty-two of them occurring in predominantly Muslim nations. Many countries in the world underwent more than one transition; most had none. Among the transitions in predominantly Muslim nations, only four brought about democratic systems and three of them (Mali, Nigeria, and Pakistan) barely lasted beyond the five-year baseline. The majority of these transitions resulted in semi-democratic regimes.

The mean age (in 2004) of the semi-democratic regimes among Muslim-majority nations over the 1970-2000 period was nearly fifteen years, and that does not count two longlived regimes that had shifted into semidemocratic status before 1970. Clearly, these are not passing interregnums. The only fully democratic countries by my definition among Muslim-majority countries in 2004 are Senegal 
and Turkey, possibly to be joined by Albania and Indonesia if they can make it over the fiveyear hurdle.

The expansion in the group of partially democratic nation states is likely to harm (or at least not benefit) international security in several ways. Partial democracies, no matter the region, represent a disproportionate amount of the world's political turmoil, according to a report from the Political Instability Task Force. In the period 1955 to 2001, mixed regimes by its tally accounted for more than one-third of all major "political instability events" (adverse shifts in patterns of governance, ethnic wars, revolutionary wars, genocides). ${ }^{3}$ Other studies confirm that there are more "life-integrity violations" (such as extrajudicial executions and torture) in semi-democratic states, for example, than in either authoritarian or democratic states. Mass killings of civilians are also most common at intermediate levels of democracy, with a decline at higher levels. ${ }^{4}$ These tragedies are plausibly explained as the consequence of social mobilization and expanded political participation in the absence of self-restraining governing institutions.

Social disorder in an intermediate regime often escalates into civil war, as implied by collaborative research by the Bertelsmann Foundation and the Center for Applied Policy Research at Munich University. The likelihood of armed conflicts taking place in so-called defective democracies (their definition) is more than three and a half times greater than in fully institutionalized democracies for the period 2003-2005. All intermediate regimes combined have a 20 percent higher chance for intrastate armed conflict than do autocracies, they report. ${ }^{5}$ Going back further to 1946 , a different study shows that semi-democratic regimes are significantly associated with an increased likelihood of civil war through $1992 .{ }^{6}$ Extending the analysis to 1816, another study finds much the same pattern: Democratic regime change is strongly correlated with internal military conflict, though the prospects for civil peace improve with time if the country evolves into an established democratic system. ${ }^{7}$ Intrastate fighting is often regionally destabilizing due to refugee flows, border incursions, rising irredentist sentiment in neighboring states, and other dangers. ${ }^{8}$

A second way partial democracies may imperil international peace is more direct: A mixed regime may have a greater propensity to use military force against another nation state (or inadvertently to invite an attack against itself). A chief reason fully established democracies are thought to resolve foreign problems peacefully is because pluralism and accountability makes them attentive to the demands of the citizenry - and hence cautious in embarking on policies that might be detrimental to the majority interest, such as starting wars. Where the representative institutions are less inclusive or only partly competitive the opposite may happen since the regime is less beholden to popular sentiment. On the other hand, a mitigating factor might be that semi-democracies are too disorganized to mobilize resources to assault a neighboring nation state - though internal disorganization also could send confused signals to potential adversaries and raise the risk of invasion.

The large-n research results on this subject are not entirely consistent. Some studies suggest that countries undergoing democratic transitions are not unusually likely to be involved in wars with neighbors, and that truncated transitions do not contribute to the probability of participation in interstate hostilities. ${ }^{9}$ However, other statistical evidence shows that states experiencing incomplete transitions are apt to start wars. Limited democracies appear to be inherently more aggressive than other regime types even beyond the period of regime transition, according to another study. Swings back and forth between democracy and autocracy are also found to increase a country's inclination to fight. ${ }^{10}$ The net effects of democratization and semi-democracy on interstate warfare are thus questions political science has yet to 
settle definitively, but it does not appear likely these factors diminish risks of external war in the short-run. At best, they simply may not add to the risks.

Terrorism is another third threat to world peace that the spread of democracy is supposed to alleviate. The official view in Washington is that democratic institutions offer citizens avenues for redress of grievances, so aggrieved citizens supposedly have little reason to turn to kidnapping, assassination or car bombing to settle scores. However, it is also plausible that democratic institutions create an optimal breeding ground for violent radicalism. There are disaffected elements in every society. The openness that goes with democratic practice reduces the cost to religious or other extremists of getting organized and planning and carrying out violent attacks. One reason to be particularly suspicious about partial democracies is that they have incentives to tolerate certain international terrorists on their territory. They may even sponsor international terrorists as a low-cost alternative to projecting official military force.

Quantitative researchers have tried to answer these questions; results are not favorable for semi-democracy. Peter KurrildKlitgaard, Mogens K. Justesen, and Robert Klemmensen have developed a model to explain the probability of terrorist attacks in different settings. It shows countries at a mid-range of democracy are more liable to experience terrorism than authoritarian or democratic countries are. ${ }^{11}$ Empirical work by Alberto Abadie also finds a non-monotonic relationship between political freedom and the incidence of terrorism, indicating countries with intermediate levels of democracy are more prone to terrorism than countries with high or low levels. ${ }^{12}$ These findings suggest that semi-democracy may be the worst of both worlds-unable either to repress violent dissent or to channel it into socially productive channels.

If illegal political violence does tend to flourish in mixed regimes, it may only have a limited impact on third parties. Cross-border terrorism is the bigger concern for the United States. An important question therefore is whether partial democracies are more or less likely to serve as a sanctuary for exporting terrorism. Alan Krueger and David Laitin have written a paper on the national origins of transnational terrorism using a three-way split among regimes. They separate countries with a middle level of civil liberties-a classification similar to the concept of partial democracy used here. According to Krueger and Laitin, these mid-level countries are a more common base for attacks than are countries with either high or low levels of civil liberties. The targets, when these terrorists go international, are usually high-income nations such as the United States. ${ }^{13}$

Neoconservatives, with their emphasis on "moral clarity," commit an either/or fallacy and ignore the existence and the security implications of partial democracy. Liberal internationalists, having made the inference that partial democracy is just a passing phase on the road to full democracy, make a comparable oversight. The literature reviewed here suggests mixed political systems present unique challenges to global peace and must be understood in their own right.

There are three broad lessons for democracy promotion policy: First only under the rarest of circumstances should military pressure be employed as a pre-emptive way to advance democracy. There are situations where military intervention is unavoidable, and that may leave the United States and its allies little choice except to try to help another country construct or reconstruct its public institutions. But we should not delude ourselves about the likelihood of a democratic political system being the result.

A second implication of the empirical literature is that U.S. foreign policy needs to be adapted better to particular countries' individual circumstances. In fact this is already done pragmatically. But rather than an ad hoc 
approach, which exposes the United States to charges of hypocrisy and double-dealing, it would be best to confront the issue of mixed regimes openly. Organizational support and electoral assistance might be appropriate to helpconsolidatea new democracy, forinstance, but be wasted effort or counterproductive in a semi-democracy.

A final implication of the literature review is to take a lower profile. Partly, this means dialing back the self-righteous neoconservative oratory about freedom because it triggers a defensive response in many corners of the globe that damages U.S. standing and influence. There should be a subtle shift in orientation, from campaigning for democracy to supporting it, taking the cues from local democratic forces as opposed to trying to get out ahead of the process as the forward strategy of freedom claims to do.

In the end rule-bound democracy is largely produced from within, not spread from the outside in a predictable manner. The Bush policy of blustering, occasionally violent, but universalistic democracy promotion wastes U.S. resources and is counterproductive in furthering the ultimate goal, which is to add to the world population of fully democratic states. The next administration needs to recognize that textured democracy promotion has a much better chance of serving U.S. national interests than does a one-dimensional blanket Wilsonianism.

\section{Endnotes}

'George W. Bush, "President Bush Delivers State of the Union Address" (The White House, January 31, 2006).

${ }^{2}$ The Polity IV Project is maintained by Center for International Development and Conflict Management, University of Maryland, College Park, Md., http://www.cidcm.umd.edu/polity/.

3 Jack A. Goldstone, Robert Bates, Ted Robert Gurr, Michael Lustik, Monty G. Marshall, Jay Ulfelder, and Mark Woodward, "A Global Forecasting Model of Political Instability" (Paper presented at the annual meeting of the American Political Science Association, Washington, DC, September 3, 2005).

${ }^{4}$ Helen Fein, "More Murder in the Middle: Life Integrity Violations and Democracy in the World," Human Rights Quarterly, Vol. 17, No. 1 (February 1995), p. 177; William Easterly, Roberta Gatti, and Sergio Kurlat, “Development, Democracy, and Mass Killings," Journal of Economic Growth, Vol. 11, No. 2 (June 2006), p. 135.

${ }^{5}$ Cited by Aurel Croissant, "Political Violence, Terrorism, and Transformation to Democracy and Market Economy: Findings of the Bertelsmann Transformation Index 2006," Strategic Insights, Vol. 4, No. 12 (December 2005).

${ }^{6}$ Errol A Henderson and J. D. Singer, "Civil War in the Post-Colonial World, 1946-92," Journal of Peace Research, Vol. 37, No. 3 (May 2000), p. 289.

${ }^{7}$ Håvard Hegre, Tanja Ellingsen, Scott Gates, and Nils Gleditsch, "Toward a Democratic Civil Peace? Democracy, Political Change, and Civil War, 18161992," American Political Science Review, Vol. 95, No. 1 (February 2001), p. 44.

${ }^{8}$ Reported by Michael D. Ward and Kristin M. Bakke, "Predicting Civil Conflicts: On the Utility of Empirical Research" (Paper presented at the Conference on Disaggregating the Study of Civil War and Transnational Violence, University of California Institute of Global Conflict and Cooperation, San Diego, March 7-8, 2005).

${ }^{9}$ William R. Thompson and Richard Tucker, "A Tale of Two Democratic Peace Critiques," Journal of Conflict Resolution, Vol. 41, No. 3 (June 1997), p. 445; David L. Rousseau, Democracy and War: Institutions, Norms, and the Evolution of International Conflict (Stanford, Cal.: Stanford University Press, 2005), p. 279.

${ }^{10}$ Edward Mansfield and Jack Snyder, Electing to Fight: Why Emerging Democracies Go to War (Cambridge, Mass.: MIT Press, 2005), p. 134; Sandeep Baliga, David O. Lucca, and Tomas Sjöström, "Domestic Political Survival and International Conflict: Is Democracy Good for Peace?" (Working paper, Kellogg School, Northwestern University, April 2007); Kristian Gleditsch and Michael Ward, "War and Peace in Space and Time: The Role of Democratization," International Studies Quarterly, Vol. 44, No. 1 (March 2000), p. 26.

${ }^{11}$ Peter Kurrild-Klitgaard, Mogens K. Justesen, and Robert Klemmensen, "The Political Economy of Terrorism, Democracy and Freedom," Public Choice, Vol. 128, Nos. 1-2 (July 2006), p. 304.

${ }^{12}$ Alberto Abadie, "Poverty, Political Freedom, and the Roots of Terrorism," American Economic Review, Vol. 96, No. 2 (May 2006), p. 51.

${ }^{13}$ Alan B. Krueger and David D. Laitin, "Kto Kogo? A Cross-Country Study of the Origins and Targets of Terrorism," in Suicide Missions and the Market for Martyrs, ed. Eva-Marie Meyersson Milgrom (Princeton, N.J.: Princeton University Press, forthcoming). 


\section{Fixing International Security Reforming the Security Council}

The United Nations Security Council is the most important organ in the United Nations, charged with determining "the existence of any threat to peace, breach of peace, or act of aggression" and to "maintain or restore international security" with military force if necessary. ${ }^{1}$ The first attempts at reforming the Security Council was made on December 17, 1963, where the United Nations General Assembly voted to amend Article 23 of the UN charter, increasing the non-permanent members of the Security Council. ${ }^{2}$ More recently, the former-Secretary General Kofi Annan's "High Level Panel on Threats, Challenges and Changes" urged the nations to expand the membership in the Security Council and to expand the number of permanent members who may or may not be able to wield the veto power. ${ }^{2}$ This article will examine the opposing viewpoints on the issue of Security Council reform and discuss the recently proposed plans of reform.

It is composed of fifteen member states, of which five are permanent and vetowielding member states - the United States, Russian Federation, the People's Republic of China, the United Kingdom, and France - and ten elected member states which rotate on a bi-annual basis. The Council was created on 17 January, 1946, following the devastation of World War II, and its authority is derived from the fact that it is the only body in the United Nations with legal sanction behind its resolutions and the ability to sanction military actions in order to maintain international stability. The Korean War was the first instance in which the council was able to rally the international community in restoring the regional power-balance and stability; the
United States-led UN coalition, supported by armed forces of twenty different nation-states, sought to "to repel the armed attack and to restore international peace and security in the area." " The Security Council has been and is at the forefront of every international crisis, and this is further highlighted by the fact that it is the only body in the United Nations where its members have to be present in the headquarters all the time for fast and flexible response and mobilization.

Since the primary international body involved in helping to mediate and to end violent conflicts is the Security Council, many plans have been called forth to reform the Security Council into a more representative, flexible, and transparent body in mobilization. Furthermore, reforms are seen as necessary in maintaining the council's waning political legitimacy amongst the members of the United Nations. ${ }^{10}$ The political legitimacy of the Council is particularly relevant because, although the council's decisions have the force of law, it must rely upon the inherent, trust and faith of its member states to carry out its resolutions. Without any political legitimacy, the council's resolutions would be ignored and as such the effectiveness of the Council would wane and soon become obsolete.

Although there are many proposed plans for the reform of the Security Council, the three most prominent ones are the G4 Plan, Model A Plan, and Model B Plan, which agree in principle that increasing representation is the most important matter in Security Council reform, and advocates upon expanding the membership of the Security Council in underrepresented areas of the world. ${ }^{5}$ Former Secretary-General Kofi Annan - in support 
of the G4 Plan - urged the "member states to make the Security Council more broadly representative of the international community as a whole, as well as of the geopolitical realities of today." ${ }^{2}$ In particular, four nations of Brazil, Germany, India, and Japan are seated by the G4 Plan as permanent members of the Security Council with no veto powers, while two African nations as permanent but non-veto wielding members are seated, with South Africa, Nigeria, and Egypt being the leading contenders. In addition, it calls upon reconsidering the veto powers for the newlyadded permanent nations based on the performance of the Security Council. Although Japan announced in 2006 that it would be working on a separate resolution for claiming a permanent seat on the Security Council, it still supports the principles outlined by it. ${ }^{6}$

The Model A Plan calls for creating six new permanent seats, with two from Africa, two from Asia and the Pacific Islands, one from Europe, and one from the Americas. It also advocates creating thirteen new nonpermanent seats with four proportioned for African states, three for Asia and the Pacific Islands, one from Europe and four from the Americas, ensuring that there would be at least six member-states on the Council at all times from every part of the globe. Similarly, eight new permanent members with Asia, Africa, Europe, and the Americas receiving two seats each, and eleven non-permanent seats, of which four would be given to African states, three for Asia and the Pacific Islands, one for Europe, and three for Americas, are called for by the Model B Plan. ${ }^{2}$

Recent African leaders' expression of a need for"permanent African representation ... to bring an end of hegemony of [more] western nations" in the Security Council has induced them to introduce their own plan, highlighting the desires of many under-represented nations to seek permanent representation. The African leaders called for new permanent and veto-wielding members with nine new non-permanent members. Adapted from the UN General Assembly resolution A/60/ L.41, of these ten new seats, African leaders demanded two new permanent seats and two non-permanent seats for Africa, the rest being evenly proportioned for Asia, Eastern Europe, and Latin America. ${ }^{1}$

Supporters of Security Council reform point out that plans to expand the Security Council will enfranchise more nations into the international system. Many nations argue that the Council, the most powerful organ of the United Nations, is not representative of the international system, with most of its power centralized under a few veto-wielding nations. Increased membership strengthens the political will of the Council to act by ensuring that at least some of its members will react to grave crises affecting their regions. For instance, during the Rwandan Genocide, most nations on the Council at the time had no direct connection or interests with Rwanda and did not want to get involved in a bloody and costly matter. Therefore, increasing the number of members makes the council more responsive to the needs of the international community as its membership would be more diverse and power would not be centralized under the five permanent members of the Council, none of which are from Africa. ${ }^{7}$

Also linked to this is the specific argument that adding veto powers would ultimately cause the Council to stall and would accomplish less in its tenure. However, in the last two decades the veto power has only been used on nineteen occasions, with the vast majority coming from the United States and the Russian Federation. ${ }^{8}$ The power of the veto is rarely used and only used if it greatly conflicts with the policy of the nations involved. Therefore, the decision to give more members the power to veto would rarely conflict with peace keeping operations as current candidates for the new seats such as Brazil (who contributes the second largest amount of peacekeepers and funds in South America) are already active participants in international peacekeeping. ${ }^{5}$ Also, the three 
proposed plans - except for the G4 plan which may consider giving the new permanent members veto power after fifteen years - do not give veto power to the new permanent members, meaning that the power would not be abused by the new members.

The potential members for the new permanent seats no doubt must be wellqualified, based on such factors as: economic size and commitment to foreign aid, financial and peacekeeping force contribution to the UN, status as a key regional power, and commitment to international peace and security. The four candidates for permanent seats under the G4 Plan seem extremely wellqualified according to these criteria. Japan and Germany are two of the biggest financial contributors to the United Nations and the economic and political powerhouses of their respective regions. Brazil is both the largest country in Latin America in terms of GDP and population and the second-largest contributor of the peace-keeping force in South America, claims supported by virtually all Latin American nations, save Argentina. India is an emerging regional power and the world's largest liberal democracy. Its contribution of the thirdlargest number of troops in the world for UN-mandated peacekeeping missions marks India's commitment to international stability. ${ }^{5}$ Despite the credentials of the leading candidates for Security Council reforms, it is important to be aware of the difficulties and problems in expansion. One of the major problems with the concept of increasing the Security Council's membership is the idea of efficiency. The primary reason why the Security Council is given the power to handle issues of international peace and security, as opposed to the General Assembly, is due to the fact that the Council needs to be able to act quickly and decisively on any crises. A common criticism of the Council is its inability to respond to international crises. For example, in the Darfur Crisis, the Council's sluggish response was partially caused by the fact that the global community could not even agree on how to respond to the violence. ${ }^{9}$ If the council's membership had been even larger it is fair to argue that the council would be even slower to act, as the Council's members would spend more time clashing with each other rather than coming up with substantive solutions. The unique harm that comes from this expansion of the Council is that it can do the very thing that proponents of expansion argue, it could de-legitimize the Council. When the Council cannot solve the very problems that it was intended to solve, then the entire institution can be seen as increasingly worthless. ${ }^{11}$ This legitimacy problem becomes increasingly more apparent when answering the question on which countries should be permanent members of the Security Council.

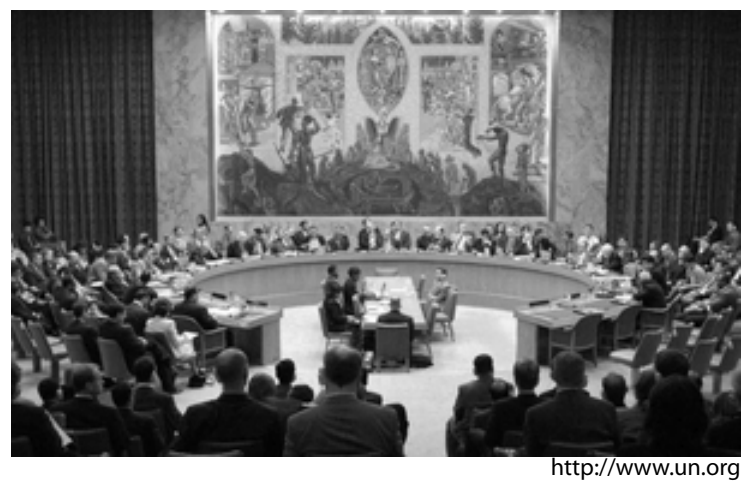

What should the qualifications be for nations being permanent members of the Security Council? For the most part, the Council members are expected to respect the very ideals of the UN Declaration of Human Rights and basic liberal democratic values. The members of the Security Council also expected to have sizeable militaries and large economies. However when examining issues such as geographic breadth, it is apparent that none of these criteria have any strong correlation with geographic breadth besides western industrialized nations. It can even be argued that nearly the entire continent of Africa does not possess all of these attributes. The only geographic area that really fulfills most of these conditions is the Western industrialized world with a few exceptions. Many nations 
that are being considered do not appear to be the best examples of nations that embody these concepts. Thus, the Council risks losing its legitimacy when unqualified states are given permanent seats in the Council.

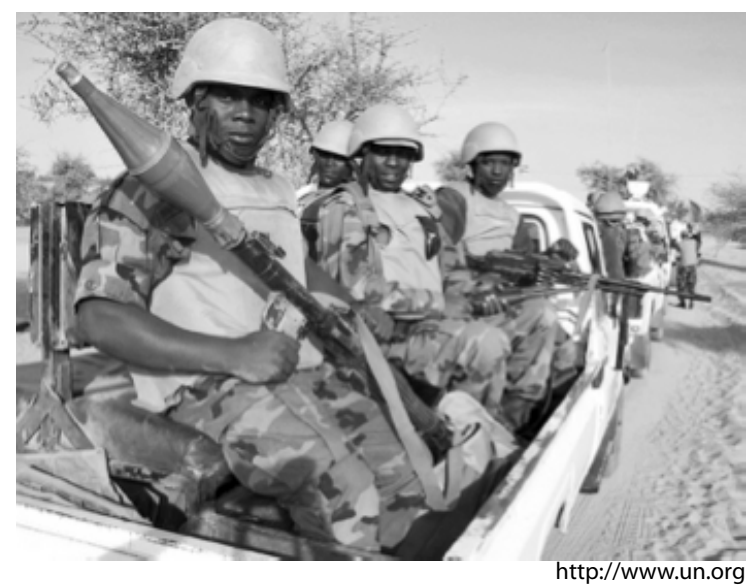

When looking at the prominent contenders for permanent Security Council seats, it is evident that many of them are less than ideal candidates. Looking at two case examples, it is not hard to see the inherent difficulties in judging which candidate is more qualified. For example, India seems an ideal candidate as it represents a large population and has a significant economic and military presence in the world. However, its refusal to sign important treaties, such as the Nuclear Non-Proliferation Treaty, raises concerns about India's qualifications. Germany, a seemingly ideal candidate, fulfills most of the criteria for permanent representation, except for the fact that the Western powers - the United States, France, and United Kingdom - are very overrepresented in the Council. With over half of the Western powers being permanent members, one could easily contest that Germany's candidacy does not fulfill the spirit of increasing geographic diversity. Thus, the ideas of geographic breadth and qualifying characteristics start to look more and more mutually exclusive of one another.

The issue of which country is actually qualified to permanently represent a broad geographic area also poses a contentious issue. Many continents, such as Asia, are so diverse that there is very little in common between nations. The idea that many plans include adding three more "Asian" states is simply inadequate to address concerns of representation from Asia. It would be hard to imagine that Pakistan, Laos, or any Middle Eastern nation would approve of India being its representative in Asia. Similarly, when we consider Latin America, most Latin American nations would balk at the idea of Brazil being the representative of the continent as a whole. The fact that Brazil is the largest nation in the region does not hide the fact that it also does not share the language or the cultural similarities that unite much of Latin America. 12

Although there is broad consensus that reform of some kind is need to increase the political legitimacy of the Security Council and make it a more representative and flexible organ, there are many opposing viewpoints on the main proposed reform plans because of their merits and faults. Proponents of reforming the Security Council argue that the current power structure of the Security Council represents more of an oligarchy than a legitimate representation of the international community as a whole. This current power structure, reformers argue, does not necessarily serve the international community as a whole but rather the wishes and whims of its most powerful permanent members. Therefore it is essential to include more members in the Council to ensure that the Council reacts to all major international crises. Although those who disagree with the three major proposed plans do not necessarily discount the idea of the reform as a whole, they point out that the debate of this magnitude must be carefully considered, examined, and regulated.

These opponents to reform claim that although increasing the membership of the Council may allow for more crises to be put on the table, the ability to react to these crises swiftly would be severely hampered. They 
contend that the addition of new members would simply bog the Council in endless debate and prevent them from acting. Also these opponents are skeptical that any reform could be implemented as it is close to impossible to pick out ideal candidates. This is due in no small part to the inherent difficulties in fulfilling the idea of geographic diversity while simultaneously ensuring that any prospective nation has significant standing in the international community.

Keeping this in mind, the international community should not lose sight of the positive and beneficial aspects of the Security Council reform because of the debate and objections around the proposed plans of reform. The inherent skepticism in the con's arguments and the goals that the proposition argues for should both be taken account when deciding what course of action should be taken. The council is not only clearly in need of some sort of change in order to adapt to the realities of the twenty-first century, but also for nations to reach a feasible solution that works. Only after addressing the concerns of opponents to reform, can the Security Council truly claim to be an effective and undisputed legitimate international body.

\section{Endnotes}

'The UN Charter and Security Council Resolutions. United Nations. <http://www.un.org $>$

${ }^{2}$ Annan, Kofi. 2005. "In Larger Freedom: Towards Development, Security, and Human Rights for All." Global Policy Forum <http://www.globalpolicy.org/reform/initiatives/annan/2005/followupreport.pdf>

${ }^{3}$ Pan, Ester. "Humanitarian: A Decade After Rwanda." Council on Foreign Relations: A Resource for Nonpartisan Information and Analysis. 1 April 2004. <http://www.cfr.org/publication/7715/humanitarian.html?breadcrumb=\%2Fregion\%2F191\%2Frwanda>

${ }_{4}^{4}$ Monthly Summaries of Contributors of Military and Civilian Police Personnel.United Nations <http://www.un.org/Depts/dpko/dpko/contributors/2007/ aug07_2.pdf>

${ }^{5}$ Working Methods Reform. Center for UN Reform Education. <http://www.centerforunreform.org/node/36 $>$

${ }^{6}$ Oshima, Kenzo. "Statement by H.E. Mr. Kenzo Oshima, Permanent Representative of Japan to the United Nations At the Plenary of the General Assembly." The Ministry of Foreign Affairs of Japan. 20 July 2006 <http://www.mofa.go.jp/announce/speech/un2006/un0607-3.html>

${ }^{7}$ Wilkinson, J., O'Sullivan, C. "The UN Security Council and Iraq: Why it succeeded in 1990, Why it Didn't in 2003, and why the United States Should Redeem it." University of North Carolina, Chapel Hill. <http://www.unc.edu/depts/diplomat/archives_roll/2004_01-03/wilkinosull_unsec/wilkinosull_ p2.html

${ }^{8}$ Richard Falk. "Sovereignty and Human Rights: The Search for Reconciliation." Global Policy Forum. May 2000. <ttp://www.globalpolicy.org/nations/ future/0312falk.htm>

${ }^{9}$ Prunier, Gerard. Darfur The Ambiguous Genocide. Ithaca: Cornell University Press, 2005. pp 141-148

${ }^{10}$ Slaughter, Anne-Marie. "Security, Solidarity, and Sovereignty: The Grand Themes of UN Reform" The American Journal of International, Vol. 99 , No. 3. (July 2005): 619-631.

${ }^{11}$ Albright, Madeleine K. “United Nations." Foreign Policy 138. (Sep. - Oct., 2003): 16-24.

${ }^{12}$ Blum, Yehuda Z. "Proposals for UN Security Council Reform” The American Journal of International Law, Vol. 99 , No. 3 (Jul 2005): 632-649 


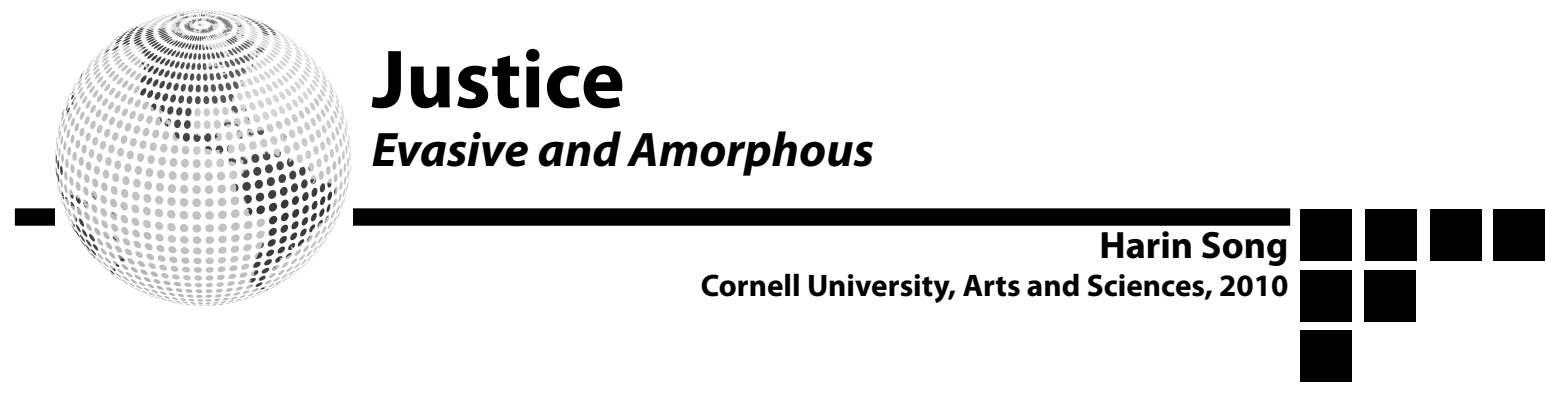

With mass atrocities ongoing in Darfur and past atrocities yet to be addressed, the question of how to achieve accountability for human rights violations in the context of post-conflict society has never been a more pressing concern. But justice exists in many forms and requires more than, and possibly something other than, the criminal prosecution of perpetrators. Justice can encompass, depend on, and affect other elements, such as political transition, democracy consolidation, institutional reform, long-term human rights protection, judicial capacity-building, and interpersonal reconciliation. The past several decades have witnessed varying approaches to justice which met varying degrees of difficulty and success. This paper analyzes three different pathways taken to achieve justice: truth commissions; hybrid courts and a truth and reconciliation commission; and a combination of an ad hoc international criminal tribunal, national criminal courts, and community-based local courts. I will argue that international support or reinforcement, which is usually necessary, cannot help without proper integration into national or domestic mechanisms and that where nations elect to hold truth commissions over trials, international pressure and assistance must follow to ensure that the commissions' recommendations are acted upon.

\section{Introduction to three approaches}

In Chile, the 17-year military dictatorship of General Augusto Pinochet left more than 3,000 people dead and missing. ${ }^{1}$ Disappearance, the prevalent form of human rights abuse in Chile, was rationalized by those in power as necessary for national security but became "a license to torture and murder with impunity." ${ }^{2}$ El Salvador's 12-year civil war between the government and left-wing guerrillas in the 1980's and 1990's resulted in more than 70,000 deaths and mass human rights violations. ${ }^{3}$ Following these decades of violence, the Truth and Reconciliation Commission (Rettig Commission) in Chile, and the Commission on Truth in El Salvador were both created to investigate and advise, but neither was granted prosecutorial or judicial powers. They were, however, allowed to transmit their findings to the courts for appropriate legal action. Yet the commissions themselves described their respective judicial systems as deficient or implicated them in cover-ups. Furthermore, both countries had amnesty laws in place. ${ }^{4}$ Thus the commissions' mandateessentially only entailed investigation and recommendation.

In 1999, the people of East Timor voted to separate from Indonesia. In the period before and after the referendum, an estimated $70 \%$ of government infrastructure was destroyed, 60,000 houses were burned, 500,000 civilians displaced, $1000-2000$ victims killed, and hundreds of women raped, as part of the Indonesian government and military's policy of systematic violence to prevent and punish participation in the plebiscite. ${ }^{5}$ The United Nations Transitional Administration in East Timor (UNTAET) soon after took charge and was mandated with establishing a process of accountability for significant violations of international humanitarian law. ${ }^{6}$ Hybrid courts were chosen as the means because localjudicial capacity was lacking and no international court existed to function in place of the weak domestic court system. UNTAET decided that 
panels comprising two international judges and one East Timorese judge would try serious crimes; ${ }^{7}$ prosecutors and investigators were drawn from other countries and the local population. The concept of hybrid courts "envisages international standards applying throughout, and full respect for due process and the rights of the accused, while at the same time honouring a State's need to retain sovereignty through adequate involvement in the process." ${ }^{8}$ However, designing and implementing a scheme tailored to the needs and capacities of the host nation and which simultaneously meets international standards proved to be extremely challenging. ${ }^{9}$ The situation was complicated by two other simultaneous judicial processes, Indonesia's ad hoc Tribunal in Jakarta based on the ICC and the East Timorese Commission for Reception, Truth and Reconciliation, which has no powers to consider or grant amnesty for serious atrocities. $^{10}$

In Rwanda, some 800,000 Tutsi and politically moderate Hutu were murdered within 100 days. ${ }^{11} \quad$ The International Criminal Tribunal for Rwanda (ICTR), whose jurisdiction spans only the events of 1994, has been criticized for its invisibility and inaccessibility to the Rwandan people ${ }^{12}$ as well as its inability so far to present a comprehensive and cohesive history of the genocide and preceding events. The national courts presented the same problems of inaccessibility, as the proceedings of their trials, held in provincial capitals, are not broadcast over radio or television. ${ }^{13}$ Thus, to expedite and improve the process of trying the perpetrators of genocide, Rwanda's Transitional National Assembly passed the gacaca ${ }^{14}$ law in January 2001, and since then about 11,000 gacaca tribunals have been established throughout Rwanda. ${ }^{15}$ Each tribunal comprises nine lay judges elected by the local community and briefly trained before the trials commence. Nicholas Jones describes the national court system as "classical trial method justice" and the gacaca "a modernized version of a traditional
Rwandan dispute resolution mechanism."16 Together, the ICTR, the Rwandan National Judiciary, and the gacaca courts are in the process of adjudicating approximately 750,000 perpetrators of genocide, with Rwandan military courts and international third-party trials operating peripherally. ${ }^{17}$

\section{Contribution to Justice: For Perpetrators and For Victims}

The major premise for truth commissions centers on their ability to discover and disclose information on the violence which took place. As Mark Ensalaco writes, a truth commission investigation can "end the anguished uncertainty of the families of the disappeared" and uphold Additional Protocol I to the Geneva Convention, which guarantees the right of families to know the fate of their members. ${ }^{18}$ However, this supposed merit of truth commissions does not always hold up in practice. For example, although the Chilean Rettig Commission offered its report as a legal basis for determining the status of disappeared persons and reached definitive conclusions on 2759 out of the approximately 3400 (957 involving the detained-disappeared) cases of violence it investigated, it only looked into cases involving deaths and consequently omitted tens of thousands of cases of torture, forced exile, and other significant human rights violations. ${ }^{19}$ In El Salvador, the Truth Commission only reported on 33 "symbolic cases" out of the 22,000 which were brought before it. ${ }^{20}$

However, the Rettig Commission did help ensure material compensation for victims: its reports, with the force of a final, legal determination, served as the basis for surviving families' property and inheritance claims and application for social security, health, educational, and housing benefits. ${ }^{21}$. The Salvadoran Truth Commission likewise called for, in less detail, material compensation to the victims of violence. Further, the commissions' recommendations led to "a measure of 
punishment" in both countries.22 In El Salvador, military officials, public officials, and judges identified by the Truth Commissions were penalized with dismissal or harm to personal reputation and to institutional prestige. Even in Chile, where dismissal of military officers has not been possible, the commission report's "indictment of the military" has undermined the armed forces' authority and credibility. The Chilean military attempted to rebut the Rettig Commission's report in their official response but largely failed, and the published record of their violations of international humanitarian law was left standing. ${ }^{23}$ Thus, although the Rettig Commission and Salvadoran Truth Commission did not prosecute individuals, their reports directly and indirectly resulted in some consequences for the perpetrators actions.

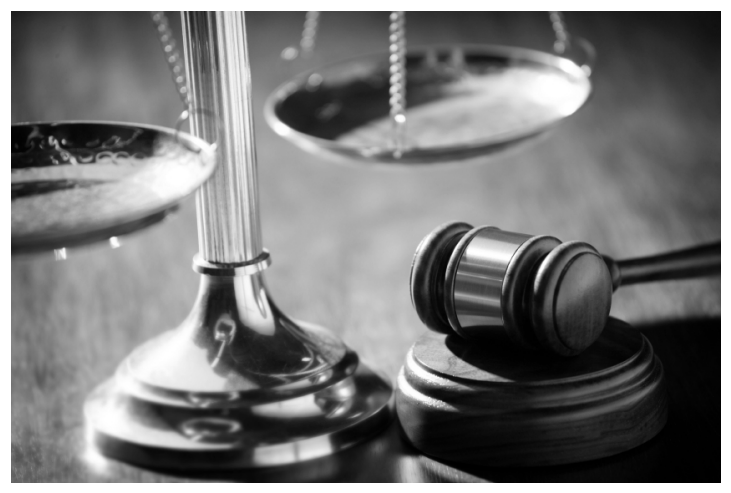

The Ad Hoc Human Rights Court on East Timor in Jakarta has not contributed at all to bringing human rights abuses to account, largely due to "a lack of political will in Jakarta to prosecute senior Indonesian civil and military officials responsible for the violence." ${ }^{24}$ In the cases decided thus far, all nine military and police personnel have been acquitted; the only two persons convicted are East Timorese. ${ }^{25}$ Meanwhile, the Serious Crimes enterprise ${ }^{26}$ in the District court of Dili created under UN auspices has under-performed and been criticized for bad leadership and poor management. Those involved in running this hybrid court have found the scheme immensely challenging, "with minimal resources and apparent lack of institutional support."27 According to Linton, the International Criminal Court (ICC)'s legal regime was basically "grafted" onto a district court in a severely destitute country with "a dysfunctional criminal justice system with novice legal personnel."28 As a result, thisjudicial mechanism has been largely ineffective. A serious lack of human and material resources has impeded the work of the Serious Crimes Investigation Unit; investigations of the overwhelming majority of crimes against humanity and war crimes committed during 1999 have been delayed or prevented. A number of detainees have been released on grounds of insufficient evidence. ${ }^{29}$ East Timor's hybrid process is also weak because the Dili court's main targets are in Indonesia and thus outside of its mandate of operation. ${ }^{30}$

In Rwanda the new Tutsi-dominated government adopted a policy of "maximal accountability" for genocide and crimes against humanity because of "the entrenched and institutionalized culture of impunity." ${ }^{\prime 31}$ The Rwandan government thus placed the prosecution and punishment of perpetrators at the center of its attempt to achieve justice and reconciliation. ${ }^{32}$ It did not, however, want to use the legal proceedings of an international ad hoc tribunal. ${ }^{33}$ Nevertheless, in November 1994 the international community created the ICTR, which has arrested 66 people, tried 21 individuals, and rendered eight convictions and one acquittal, as of March 1, 2004. There are seven ongoing trials with 20 defendants. ${ }^{34}$ Clearly the ICTR is moving extremely slowly and it is seen as so by Rwandans. ${ }^{35}$ A 1998 UN internal affairs report described the critical failure to hire lawyers and investigators in the prosecutor's office in addition to the continuing problems in procurement, recruitment, witness protection, and management. ${ }^{36}$ As Neuffer writes, the ICTR in 1996 "mixed the worst of African tribal politics with UN bureaucracy." ${ }^{137}$ The ICTR is also physically far-removed from the Rwandan people: the prosecutor's office 
was located in Rwanda, but the court, judges, and administrative staff operated in Arusha, Tanzania. Both offices were overseen by a chief prosecutor in The Hague, Netherlands. ${ }^{38}$

Nonetheless, the ICTR is the first international court to attain a conviction for the crime of genocide; it has also solidified rape's inclusion in the definition of a crime of genocide and set a precedent for court action against high-ranking government officials. ${ }^{39}$ By advancing and bolstering international human rights norms in this manner, it has likely furthered the protection of human rights in individual countries.

Meanwhile, the Rwandan national criminal courts suffered from the destructiveness of the genocide itself. Individuals involved in judicial operations numbered 1459 before 1994; this number shrank to 393 after the genocide. The surviving national judiciary was therefore overwhelmed by the masses of people accused, arrested, and incarcerated on allegations of genocide crimes. Between December 1996 and June 2003, the specialized chambers created for genocide trials have tried 8,820 genocide suspects, less than ten percent of detainees; 70 individuals were sentenced to death in 2002. ${ }^{40}$ According to Jones, the domestic trials have been criticized for corruption, pervasive due process violations, lack of competent legal professionals, detention without judicial review, and bias in the form of victor's justice. ${ }^{41}$ International monitors found that the Rwandan national courts were "flagrantly onesided" and the trials that resulted in the death penalty were "deeply flawed."42

Establishing community-based gacaca courts - the third component of Rwanda's approach to transitional justice - made sense given the Rwandan genocide's mass involvement and execution by mostly average citizens. These factors, along with "the internal need to begin the process of rebuilding a highly ethnically-polarized nation,"43 led the government to introduce the gacaca as an alternative mechanism for justice and reconciliation. A gacaca court has a distinct purpose in each of two phases: first to reveal the truth about the activities which took place, and then to hold trials and deliver sentences for category 2 and category 3 crimes. ${ }^{44}$ Justice through the gacaca courts may resonate more with the Rwandan people since the duties and obligations that accompany the process are shared by the population, including women, and are based on the idea of citizenship. ${ }^{45}$ However, the gacaca courts have faced the same challenges in actual proceedings as the ICTR and the national judiciary. According to Amnesty International, gacaca sessions regularly start late and are often canceled because a quorum has not been reached. Moreover, though gacaca courts are supposed to be a participatory form of justice, community members serving as judges"appear to be afraid of providing a true account of what they know about the genocidal crimes committed." ${ }^{46}$ Gacaca has also not helped in expediting the trial of detainees. Less than ten percent of the 11,000 tribunals established in June 2002 have become operational, and as of 2004 no actual trials had taken place. Like the other justice mechanisms in Rwanda, the gacaca are overwhelmed by the tens of thousands of confessions and incriminations being processed by the Ministry of Justice. ${ }^{47}$

\section{Contribution to \\ Interpersonal Reconciliation}

The Rettig Commission received a mixed response from the public. At its start, over 70 percent of Chileans felt the commission would aid reconciliation. Soon after the report's release, the Chilean public was evenly split on the issue of whether the commission's findings advanced reconciliation. ${ }^{48}$ According to Brahm, "victim's groups thought the commission was good as far as it went, but they still wanted punishment and more information on the fate of their loved ones" and, "the continued reluctance to discuss the past throughout much of the 1990's suggested that Chileans were far from reconciled with their past." ${ }^{\prime 49}$ 
In El Salvador, the truth commission recommended symbolic reparations for the victims and the creation of a follow-up body to continue the commission's investigation into the murder and disappearance of thousands during the civil war. However, according to Brahm, UN Secretary-General Kofi Annan observed that the commission's recommendations concerning national reconciliation were largely ignored. ${ }^{50}$

In East Timor, the Commission for Reception, Truth, and Reconciliation (CAVR) is mandated to inquire into and establish the truth about human rights violations committed between 25 April 1974 and 25 October 1999, to assist victims, and to conduct Community Reconciliation Procedures. ${ }^{51}$ According to UNTAET regulation, the Commission and the Serious Crimes mechanisms are to operate in a complementary manner. Following much debate it was decided that evidence found by the Commission would not be protected by privilege. ${ }^{52}$ However, the Steering Committee's widespread public consultations found that "the overwhelming majority of East Timorese wanted a process which included strict legal punishment for the most serious offenders but also provided a more lenient, communitybased mechanism to deal with perpetrators of less-serious crimes." ${ }^{\prime 5}$ A combination of traditional and formal justice systems seemed to be in order. Thus, Community Reconciliation Procedures (CRPs) were set up in which perpetrators must admit and apologize for all of their crimes in a community-based hearing, and then undertake community service or other acts of reconciliation; this process is registered with the nearest District Court. Afterward, they are safe from criminal prosecution. According to Burgess, both national and international observers consider the CRP program "a resounding success." ${ }^{54}$ More than 1500 admissions of guilt were taken and 1404 perpetrators completed the CRP district hearings. When the CAVR conducted a mid-program follow-up with participants, over $90 \%$ of those interviewed stated that the process had been positive and that they were satisfied with its results. Every perpetrator interviewed and most victims also stated that after the CRP process they felt perpetrator-victim relations had improved. ${ }^{55}$ The survey also concluded that for victims, the most important factor for reconciliation was the strength and sincerity of the perpetrators' public admission and apology, not the nature or degree of their punishment. ${ }^{56}$

In Rwanda inter-personal
reconciliation was made nearly impossible by the continuing violence between Hutus and Tutsis. In 1998 fierce clashes between extremist Hutu and the Rwandan Patriotic Army continued, and government troops retaliated harshly to cross-border raids by Hutu militia in neighboring countries. ${ }^{57}$ The courts did not ameliorate interethnic tensions. According to Neuffer, to many Rwandans, neither the international tribunal nor the national trials seemed fair, and "both Hutu and Tutsi saw themselves as victims of justice, not recipients of it." ${ }^{158}$ The lack of accessibility proved a critical failure of the Rwandan national and international trials in terms of their ability to foster reconciliation as well. According to one woman, having trials outside of Rwanda deprived genocide survivors of the chance to confront those responsible for their suffering. They needed to actually see the accused before them to have a catharsis and feel reconciliation. ${ }^{59}$ The gacaca courts have the potential to facilitate reconciliation through determination of guilt and revelation of the truth..$^{60}$ But until a clear move is made on all three tiers of Rwandan attempts at justice to impartially try all atrocities, regardless of ethnicity or political side of the perpetrator, reconciliation will likely not occur. The government has also failed to acknowledge crimes committed by the Rwandan Patriotic Front (RPF) against the Interahamwe and defeated Hutu forces. ${ }^{61}$ 


\section{Contribution to}

\section{Institution Building and Reform}

The Chilean and Salvadoran commissions analyzed the quality and independence of the judiciary and the role of the armed forces in the violence. The Rettig commission advised law schools to incorporate human rights education; the Salvadoran commission referred to the new Judicial Training School described in the peace accords and its need to train competent members for new or existing courts. ${ }^{62}$ Both commissions recommended procedural changes for appointing judges and prosecutors: in Chile the president was to identify more candidates for appointment to the Supreme Court, and in EI Salvador lower court judges were to be named by a new National Council of the Judiciary rather than the disproportionately powerful High Court. ${ }^{63}$ The Rettig Commission also called for the publication of clear standards of judicial qualification and formulation of rules of impeachment for judges who violated said standards. The Salvadoran Truth Commission recommended that lower court judges possess greater budgetary control and receive higher salaries. ${ }^{64}$ All of these reforms aimed at strengthening judicial independence, integrity, and accountability.

A crucial issue following the civil war in El Salvador and in Chile was the principle of due obedience, which requires soldiers to comply with orders regardless of their content. ${ }^{65}$ For example, in December 1981 the Salvadoran Army's Atlacatl Battalion deliberately and systematically murdered the entire civilian population of the village of El Mozote - more than 200 men, women, and children. ${ }^{66}$ Mark Danner's account of the massacre suggests that some of the soldiers involved in the operation felt uneasy about its brutality and its necessity; when Captain Salazar heard about the men's misgivings, he angrily berated their hesitation and insisted, "this is what war is." ${ }^{67}$

In Chile the Rettig Commission evaded making a decisive pronouncement on the matter of command responsibility, and only recommended scrutiny of the due obedience principle to prevent it from facilitating human rights violations. ${ }^{68}$ The Truth Commission in El Salvador went further, though its actions were still limited. It recommended a strict system of discharge for officers who violated human rights and the codification of legal penalties for said violations; it demanded the eradication of any relationship between members of the armed forces and the death squads; and it called for a special legislative commission to ensure the completion of the transition to the new model of the armed forces as delineated in the peace agreements. ${ }^{69}$ Though all of these recommendations sound appropriate, here one can imagine that the criminal prosecution of both commanders and subordinates complicit in the massacre of El Mozote might have had a significant, or at least stronger, impact on the willingness of soldiers and commanders alike to perpetrate atrocities in the future.

Since the hybrid court in East Timor failed to accomplish much in its own jurisdiction, it is doubtful that it had positive effects on other institutions in the country. There was also little domestic judicial capacitybuilding. Though the court building and all its employees were new, little guidance and training were provided, administrative staff was severely shorthanded, and files and evidence were routinely misplaced." ${ }^{\prime \prime 0}$ Meanwhile, the embryonic judicial system faltered under the continuously growing case load. Linton writes,

"The persistent failure to provide adequate support [by international actors] to the court, prosecution and defence, coupled with resentment of alleged interference in professional independence, led to difficult relations between UNTAET's Ministry of Justice and East Timorese judicial personnel...The adoption of the Serious Crimes project was viewed with much anger by the East Timorese jurists, who felt they had been excluded 
from the process and that the atrocity cases, which they had previously been dealing with, were being taken away from them by the international community." ${ }^{\prime 71}$

Thus, the international community is not truly building local judicial capacity so much as half-heartedly imposing its capacity on East Timor.

The ICTR, operating distantly in Arusha, Tanzania, has had little effect on domestic institutions and has not served to enhance the protection of political and civil liberties in Rwanda. ${ }^{72}$ Notwithstanding its poor location, the Rwandan International Tribunal has not been competent in itself, let alone helped build the Rwandan national judicial system. According to Neuffer, trials at the ICTR "sputtered along" - witnesses and defense attorneys failed to appear, prosecutors were unprepared, motions could not be found or had not been translated, and the court even lacked a reference library. ${ }^{73}$

\section{Contribution to Human Rights}

Both the Chilean and Salvadoran truth commissions furthered the promulgation of human rights by advising the adaptation of political constitutions and legal statutes to reflect international human rights standards, the ratification of any international human rights treaty, and the review of any reservations submitted with previous ratifications. ${ }^{74}$ They called for amendment of those provisions of the constitution and the military code of justice incompatible with international human rights law, as well as for institutional reforms. These recommendations led to changes in national law and legally institutionalized international human rights norms in both countries. In particular both commissions examined amparo and habeas corpus remedies, due process, criminal procedure, and administrative detention. ${ }^{75}$ The Rettig Commission in Chile "focused on the routine practice of secret indictments which compromised the rights of the accused to an adequate defense, and the incommunicado detention of suspects for inordinate lengths of time without justification." ${ }^{176}$ The Salvadoran Truth Commission reviewed the violation of suspects' rights to defense from the start of legal proceedings and to the presumption of innocence; the commission also examined the arbitrary authority of administrative officials to impose imprisonment penalties. ${ }^{77}$

It is unclear what exactly the East Timorese transitional justice mechanism will achieve for human rights in the country's future. But thus far it has pushed, to some extent, the principle of accountability for human rights violations. The Serious Crimes panel has indicted hundreds of perpetrators, including senior Indonesian military officers, though most indictees remain outside the panel's jurisdiction. ${ }^{78}$ Meanwhile the CRP program has meted out "acts of reconciliation" as punishment for perpetrators of less serious crimes. There is an understanding that human rights violators will not simply get away with impunity.

In Rwanda it is unclear how the threetiered pathway to justice will affect long-term human rights protection. The government's policy of "maximum accountability" to end the culture of impunity ${ }^{79}$ certainly condemns human rights violations and reinforces the concept that human rights must be protected. However, the lack of accountability for abuses by the Rwandan Patriotic Front and other Tutsis undermines this verbally aggressive approach to justice and perpetuates the sense that human rights are not respected in Rwanda.

\section{Conclusion}

The truth commissions in Chile and EI Salvador definitely had some positive effects. Both implicated the respective national judicial system in covering up human rights abuses and recommended amendment of provisions of the constitution and other legal statutes which were incompatible with international human rights law. As Snyder and Vanjamuri write, "While the government rejected the [Salvadoran] commission's call 
for the resignation of a long list of members of the judiciary, a reformist ruling coalition implemented some of its recommendations." 80 In Chile the judiciary was resistant to change after the transition, but in the late 1990s the Frei administration pushed the reform effort forward and these reforms" have had a dramatic effect on the judiciary and on Chilean politics more generally." ${ }^{\text {"11 }}$ For example, the number of Supreme Court justices was increased and the court has taken on a more activist approach to human rights.

In East Timor's case the "sham" nature of the Indonesian ad hoc tribunal and the incompetence of the hybrid court in Dili have impeded the pursuit of justice. International human rights norms have also not been meaningfully integrated into the domestic system. However, East Timor's Community Reconciliation Process has been fairly effective and received positive reviews by participating victims and perpetrators.

In Rwanda the ICTR, national judiciary, and gacaca courts have all been undermined by corruption, procedural problems, and the taint of victor'sjustice.The gacaca courts, due to their community-based, participatory nature, have the potential to facilitate reconciliation in a way the other two mechanisms have not, but they too must overcome their functional deficiencies.

These four case studies yield several lessons. First, accessibility by victims and visibility to the larger society are critical to any transitional justice mechanism's meaning, weight, and legitimacy. Many Rwandans feel alienated from the ICTR because much of its work is hidden and they cannot actively participate in it. Many East Timorese feel the same alienation, not because of distance, but because of friction with and lack of true collaboration with the international elements supporting their nascent national court. In Chile and El Salvador, the truth commissions' reports were published but their findings did not satisfy many of the victims. This leads to the second conclusion, which is that investigations must be extremely comprehensive, encompassing human rights violations by all sides and of all types..$^{82}$ Third, where truth commissions are used rather than prosecutions, there must be some outside recourse for victims who feel that adequate justice has not been attained and who want to further pursue accountability for the violations they suffered. Finally, international support, if provided, must be competent and adequately funded. If it is not fully capable, funded, and staffed, international judicial assistance will do little to help, if not detract from, newly developing or destroyed post-conflict national judicial systems. No approach to transitional justice has proven exceptionally effective, but each country's experience sheds light on what can be done to ensure its success in the future.

\section{Endnotes}

"Country profile: Chile," BBC News, 16 Mar 2007, <http://news.bbc.co.uk/2/hi/americas/country profiles/1222764.stm> (30 Apr 2007).

${ }^{2}$ Robert L. Maddex, "Disappearance," International Encyclopedia of Human Rights: Freedoms, Abuses, and Remedies (Washington, D.C.: CQ Press, 2000), 112.

${ }^{3}$ Tom Gibb, "US role in Salvador's brutal war," BBC News, 24 Mar 2002, <http://news.bbc.co.uk/2/hi/americas/1891145.stm> (30 Apr 2007).

${ }^{4}$ Mark Ensalaco, "Truth Commissions for Chile and El Salvador: A Report and Assessment," Human Rights Quarterly, Vol.16, No.4 (Nov 1994): 658-659.

${ }^{5}$ Human Rights Watch as cited in Patrick Burgess, "Justice and Reconciliation in East Timor," Criminal Law Forum (2004): 135-136.

${ }^{6}$ Laura Dickinson, "The Promise of Hybrid Courts," The American Journal of International Law, Vol.97, No.2(Apr. 2003): 298.

${ }^{7}$ War crimes, crimes against humanity, and genocide as well as murder, sexual offenses, and torture. Dickinson, 298.

${ }^{8}$ Suzannah Linton, "Cambodia, East Timor and Sierra Leone: Experiments in international justice," Criminal Law Forum, Vol.12, Iss.2 (2001): 2.

${ }^{9}$ Linton, 2.

${ }^{10}$ Burgess, 137-138.

1 Samantha Power, "A Problem from Hell: America and the Age of Genocide" (New York: Harper Perennial, 2002$), 334$.

${ }^{2}$ Jack Snyder and Leslie Vinjamuri, "Trials and Errors: Principle and Pragmatism in Strategies of International Justice," International Security, Vol.28, No.3 (Winter 2003/04), 32. Brahm, 24.

${ }^{3}$ Anuradha Chakravarty, "Gacaca Courts in Rwanda: Explaining Divisions within the Human Rights Community," Yale Journal of International Affairs (Winter/Spring 2006): 133.

${ }^{4}$ Literal translation: justice on the grass

${ }^{5}$ Chakravarty, 133-134.

${ }^{6}$ Jones, 13.

${ }^{7}$ Nicholas Jones, "Adjudicating the Perpetrators of Genocide: A preliminary investigation into the judicial 
response to genocide in Rwanda," (PhD diss., University of Calgary, 2006), ii.

${ }^{8}$ Ensalaco, 672.

${ }^{9}$ Ensalaco, 659-660.

${ }^{20}$ Ensalaco, 660.

2 Ensalaco, 663-664,

22 Ensalaco, 664

${ }^{23}$ Ensalaco, 665.

24 "Justice Denied for East Timor," Human Rights Watch, www.hrw.org/backgrounder/asia/timor/etimor1202bg.htm

1 May 2007.

${ }^{25} \mathrm{lbid}$.

${ }^{26}$ Mandate covers period from 1 January to 25 October 1999. Burgess, 143.

${ }^{27}$ Linton, 9.

${ }^{28}$ Linton, 12.

${ }^{29}$ Linton, 12.

${ }^{30}$ Following the evacuation of Indonesian military and Timorese militias from East Timor in September 1999, "those most responsible are likely to remain outside the reach of effective prosecution." Burgess, 140-141.

31 Jones, 78.

32 Jones, 13-14.

${ }^{33}$ Rwanda was the only country to vote against the UN resolution invoking its mandate. Jones, 15-6.

${ }^{34}$ Amnesty International, "Rwanda: The enduring legacy of the genocide and war," Amnesty International Library, 6 Apr 2004, <http://web.amnesty.org/library/index/engafr470082004> 1 May 2007.

${ }^{35}$ Elizabeth Neuffer, "The Keys to My Neighbor's House: Seeking Justice in Bosnia and Rwanda” (New York: Picador, 2002$), 342-43$.

${ }^{36}$ Neuffer, 344.

${ }^{37}$ Neuffer, 265

${ }^{38}$ Neuffer, 268.

39 Jones, 17.

${ }^{40}$ Amnesty International, "Rwanda."

${ }^{4}$ Jones, 19.

${ }^{42}$ Neuffer, 339-341.

43 Jones, 78.

44 Jones, 90-98.

45 Jones, 97-98.

${ }^{46}$ Amnesty International, "Rwanda."

${ }^{47}$ Amnesty International, "Rwanda."

${ }^{48}$ Eric Brahm, "Truth and Consequences: The Impact of Truth Commissions in Transitional Societies," PhD thesis, University of Colorado, 2002$), 162-163$.

${ }^{49}$ Brahm, 163-4.

${ }^{50}$ Brahm, 110.

${ }^{51}$ Burgess, 143-144.

${ }^{52}$ Burgess, 145.

${ }^{53}$ Burgess, 148.

${ }^{54}$ Burgess, 151.

${ }^{55}$ Burgess, 151.

${ }^{56}$ Burgess, 152.

${ }^{57}$ Neuffer, 339.

${ }^{58}$ Neuffer, 340.

${ }^{59}$ Neuffer, 377.

${ }^{60}$ Allison Corey and Sandra Joireman, "Retributive justice: The Gacaca courts in Rwanda," African Affairs (Jan 2004$): 88$.

${ }^{6}$ Lydiah Bosire, “Overpromised, Undelivered: Transitional Justice in Sub-Saharan Africa," International Center for Transitional Justice (July 2006$), 22$.

${ }^{62}$ Ensalaco, 668.

${ }^{63}$ Ensalaco, 668

${ }^{64}$ Ensalaco, 668.

${ }^{65}$ Ensalaco, 669

${ }^{66}$ Mark Danner, The Massacre at El Mozote (New York: Vintage Books, 1993), 271.

${ }^{67}$ Danner, 79,81.

${ }^{68}$ Ensalaco, 669.

${ }^{69}$ Ensalaco, 669-670.

${ }^{70}$ Linton, 12.

${ }^{71}$ Linton, 12.

72 Snyder and Vinjamuri, 25.

${ }^{73}$ Neuffer, 344.

${ }^{74}$ Ensalaco, 666.

${ }^{75}$ Ensalaco, 667.

${ }^{76}$ Ensalaco, 667.

${ }^{77}$ Ensalaco, 667.

${ }^{78}$ Burgess, 158.

79 Jones, 13.

${ }^{80}$ Snyder and Vanjamuri, 32.

${ }^{81}$ Brahm, 192.

${ }^{82}$ For example, violations which did not result in death sho 


\section{Works Cited}

Amnesty International, "Rwanda: The enduring legacy of the genocide and war," Amnesty International Library, 6 Apr 2004, <http://web.amnesty.org/ library/index/engafr470082004>1 May 2007.

Bassiouni, M. Cherif. "Searching for Peace and Achieving Justice: The Need forAccountability," Law and Contemporary Problems, Vol. 59, No. 4 (Autumn 1996).

Bosire, Lydidah. “Overpromised, Undelivered: Transitional Justice in Sub-Saharan Africa," International Center for Transitional Justice (July 2006). Brahm, Eric Brahm. "Truth and Consequences: The Impact of Truth Commissions in Transitional Societies." PhD thesis, University of Colorado, 2002). Burgess, Patrick. "Justice and Reconciliation in East Timor." Criminal Law Forum (2004).

Corey, Allison and Sandra Joireman. "Retributive justice: The Gacaca courts in Rwanda," African Affairs (Jan 2004).

Chakravarty, Anuradha. "Gacaca Courts in Rwanda: Explaining Divisions within the Human Rights Community." Yale Journal of International Affairs (Winter/Spring 2006).

"Country profile: Chile." BBC News. 16 Mar 2007.<http://news.bbc.co.uk/2/hi/americas/country profiles/1222764.stm>30 Apr 2007.

Danner, Mark Danner. The Massacre at El Mozote. New York: Vintage Books, 1993.

Dickinson, Laura. "The Promise of Hybrid Courts." The American Journal of International Law, Vol.97, No.2 (Apr. 2003).

Ensalaco, Mark. "Truth Commissions for Chile and El Salvador: A Report and Assessment."Human Rights Quarterly, Vol.16, No.4 (Nov 1994).

Gibb, Tom. "US role in Salvador's brutal war," BBC News, 24 Mar 2002, <http://news.bbc.co.uk/2/hi/americas/1891145.stm> (30 Apr 2007).

Jones, Nicholas. "Adjudicating the Perpetrators of Genocide: A preliminary investigation into the judicial response to genocide in Rwanda." PhD diss., University of Calgary, 2006.

"Justice Denied for East Timor," Human Rights Watch,<www.hrw.org/backgrounder/asia/timor/etimor1202bg.htm>, 30 Apri 2007.

Linton, Suzannah. "Cambodia, East Timor and Sierra Leone: Experiments in international justice." Criminal Law Forum, Vol.12, Iss.2 (2001).

Maddex, Robert L.“"Disappearance." International Encyclopedia of Human Rights: Freedoms, Abuses, and Remedies (Washington, D.C.: CQ Press, 2000).

Neuffer, Elizabeth. “The Keys to My Neighbor's House: Seeking Justice in Bosnia and Rwanda." New York: Picador, 2002.

Power, Samantha. "A Problem from Hell: America and the Age of Genocide." New York: Harper Perennial, 2002.

Snyder, Jack and Leslie Vinjamuri. "Trials and Errors: Principle and Pragmatism in Strategies of International Justice." International Security, Vol.28, No.3 (Winter 2003/04). 


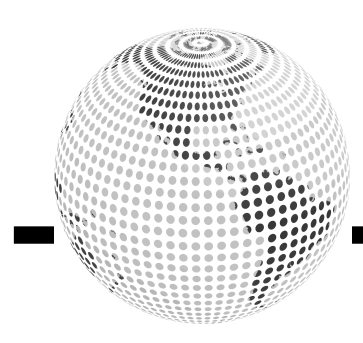

\section{Indo-Pakistani Enmity and the Reorganization of Asia}

Strategic Opportunities for China and India

Soleine Leprince-Ringuet

Sciences Po Paris- London School of Economics, 2009

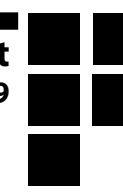

South Asia is not in itself the primary zone of interest of China. However, China has since long used the region's dynamics to achieve some of its most important strategic goals. Moreover, since India wishes to establish "its rightful place in the emerging world order", South Asia may soon gain in strategic importance. The region being dominated by the enmity between Pakistan and India, China must strategically choose its position on the conflict.

How does China use the Indo-Pakistani tensions to achieve its strategic goals? And how may India redefine its stances in the region to advance its own strategic agenda?

The Indo-Pakistani tensions represent an opportunity for China to increase its leverage on the region, because both Pakistan and India are very sensitive to the positioning of foreign powers. But new events- the end of the Cold war, the nuclear tests and the beginning of the war on terror - forced China to reassess both its strategic interests and its position on the India-Pakistan conflict. Several contemporary developments may lead China to adopt a stance more favorable to India. India itself is now "a swing state" that can choose among several options how to diminish the importance of the Pakistani factor and reorganize Asia.

\section{Centrality of the Indo-Pakistani enmity in strategic thought about South Asia}

In this section we show how central Pakistan still is in India's strategic thinking. Despite India's wish to be a regional power, whoever wishes to deal with India must first adjust his stance on Pakistan.

\section{Pakistan's preeminence in India's strategic thinking}

Since its very creation in 1947, "India's ambition to play a global role has been constrained by interstate rivalry within the subcontinent" (Nayar). India's concern for Pakistan is itself a puzzle : Why does India feel encircled and threatened, when it is seven times more populous, five times larger, and has the second largest army in the world? The response is that Pakistan's very identity is a threat to India's integrity.

The Indo-Pakistani dispute is a leftover from decolonization: Under the partition plan of 1947, Kashmir was free to accede to India or Pakistan. Its prince Hari Singh finally decided to accede to India despite Kashmir's Muslim majority. But Pakistan believes that its State will remain incomplete until the country -established as a homeland for Muslims - receives all Indian lands where Muslims are the majority. India refuses this claim, asserting that it is the very existence of Indian Muslims which preserves the secular nature of the Indian state.

From the time of its establishment, Pakistan's worldview has been dominated by the perception that it faces an existential threat from its enormous neighbor (Gill). This perception pervades all aspect of Pakistan government's policy, to the detriment of economic and social considerations. Hence Pakistan is now a land of poverty and of high social instability, characterized by an "unworkable unitary system of government, and the alienation of Pakistan's rulers from their people" (Cohen). But Pakistan is an interesting partner for China strategically. Pakistan is located in the region where South 
Asia converges with the Middle East and Central Asia; its coastline along the Arabian Sea is about 650 miles long.

Obsessed by national security, Pakistan relies on external allies to bolster its own defenses through arms supplies and diplomatic support.

\section{Will India's new ambitions lead to peace?}

Since 1998, India has shown increasing assertiveness on the Asian scene. India's "globally activist diplomacy provides the impression of a country that [is] beginning to matter" (Limaye). India has the ambition to become a mighty regional player thanks to high rates of economic growth. But India must also learn to conduct its foreign policy as a major Asian power and not just as a South Asian state.

Consequently, India now considers that peace with Pakistan would enhance its standing in the international system (Nayar), a reason that can explain the inauguration of a peace process in 2004. However, since the Simla Agreement of 1972, New Delhi advocates for a purely bilateral resolution of the conflict. A bilateral resolution is highly unlikely, though, as both sides keep rigid positions, with Pakistan still asking for a plebiscite and India claiming the unacceptability of border change.

\section{Other regional powers deal strategically with a zero-sum game}

Even as India tries to assert itself in Asia, it is extremely sensitive to any move of a regional player towards Pakistan. One can model this situation as a zero sum-game, where any positive gain with Pakistan constitutes a loss in the country's relationship to India.

Hence the strategic thinking of a regional actor towards India is inevitably linked to its strategic thinking towards Pakistan and vice versa: "the most consistent policy in both states for over fifty years has been to seek outside allies against each others"(Cohen). The conflict therefore enhances the opportunity for outside powers to intrude and exert leverage on the region. How has China dealt with this quasi zero-sum game to achieve its strategic goals? What were the main turning points that transformed its strategic thinking towards India and Pakistan?

\section{Turning points, new strategic goals and the transformation of the Indo- Pakistani issue}

In this section, we examine how the end of the Cold war, the nuclear tests and the war on terror were three major tuning points that changed the strategic goals of China and its stance on the Indo-Pakistani conflict.

\section{The end of the Cold War changes the very nature of the conflict}

During the ColdWar, the Indo-Pakistani conflict was seen as part of the struggle between the East and the West. Pakistan was backed by the United States and China. Beijing saw its relationship to Pakistan as fulfilling a double mission, resisting the Soviet Union and creating a two-front threat to India (Deepak): The internecine feud with Pakistan pulled India down to the level of Pakistan to China's benefit. Therefore after 1965, Beijing provided more military assistance to Pakistan than it has to any other state.

In response, India, first non-aligned, strategically moved closer to the Soviet Union, hoping to fall under the superpower's protection. The Indo-Pakistani conflict was endemic to the Cold War.

But the end of the Cold War changed the very nature of the conflict. China's strategic interest in Pakistan declined, as balancing Russia was no longer a priority. The ties between India and Russia also went through a steep decline because balancing China was no longer a Russian strategic goal. The IndoPakistani conflict temporally became a South Asian conflict.

The nuclear tests give the conflict a new scale and call for the reassessment of India

India's nuclear testing in May 1998 was 
a highly strategic move to demonstrate India's new assertiveness. Surprisingly, Indian Prime Minister Vajpayee used the Chinese threat as a justification for the test, writing to Bill Clinton that "India had an'overt nuclear weapons' state on its borders, which was materially helping another neighbor". Why would India do so when its ties with China were improving? India used this strategic move to appear as capable of challenging China, finally looking out of South Asia. India was also hoping to find allies sensitive to this Chinese threat, such as the US and Japan.

The nuclear tests had a great impact on Chinese strategic thinking. Of course, China, wishing to stay the only legitimate nuclear weapon state in Asia, first accused India of seeking "hegemony in the South". But China then became reluctant to support Pakistan, and defended India's stance that the problem be dealt with bilaterally. Why this shift? First, the nuclear tests led China to the reassessment of India's importance (Rajamony). China became increasingly concerned with normalizing its ties with India. Second, advocating "self-determination" could play against China's own strategic interest concerning the South China Sea islands. Third, China moderated its stance on Kashmir because China desired to appear as "a peace-making moderate" in order to be coherent with its "peaceful rise" paradigm (Cohen).

\section{The war on terror, an opportunity for new alliances with India and Pakistan}

September 11 represented a third major shift in the strategic thinking of China and India. Strategically, Pakistan chose to cooperate with the US: "By aligning with the United States in the global war on Terror, Pakistan prevented itself from being viewed, and treated, as part of the terrorist problem"(Andersen). Pakistan, inconsequence, greatly improved its international status.

But the US tried to avoid the previous zero-sum character of US policy towards India and Pakistan by establishing in 2004 a"strategic partnership" with India that would "expand cooperation" in civilian nuclear activities, high technology trade, missile defense, etc.probably in the hope to balance China.

This new "global partnership" between India and the United States, and the strengthening of the Japan-India relations (the Eight-fold Initiative for Strengthening JapanIndia Global Partnership in 2005) worried China. China acquired an observer status in the SAARC, partly in order to balance India. Does this mean that China will go back to siding openly with Pakistan in order to balance India? Probably not.

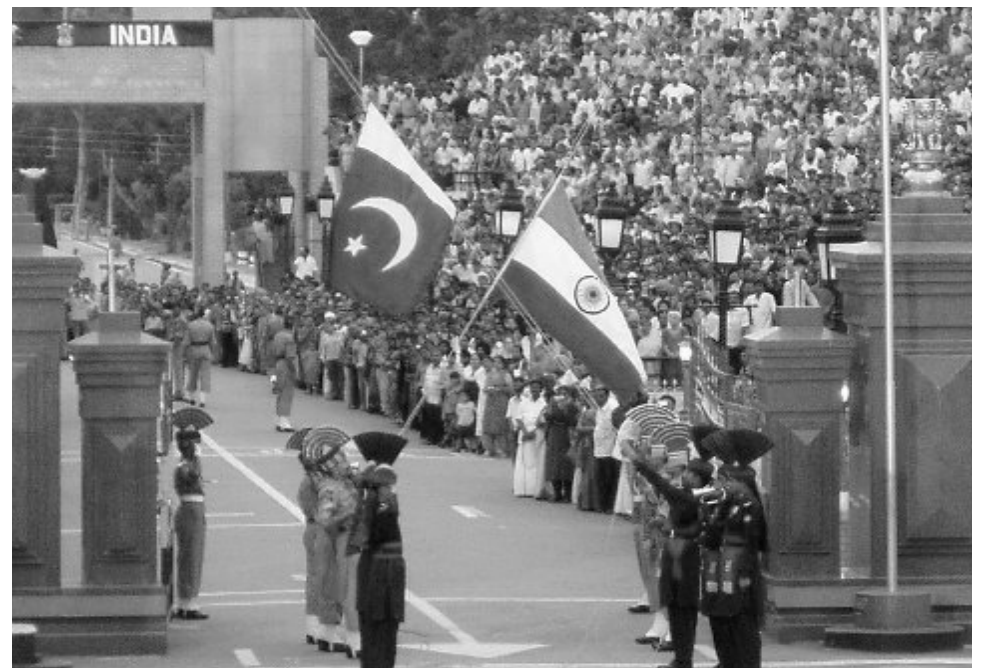


Current issues could lead to a situation more favorable to India at the expense of Pakistan

Economic concerns and regional frameworks are now important issues that could enhance India's appeal at the expense of Pakistan in the strategic thinking of China. However, this will largely depend on India's own strategic choices among the different options for the reorganization of Asia.

\section{How could India's rise play out on the Indo- Pakistani conflict?}

Beijing likes to say that economic development is now its first priority. As India develops, India becomes an attractive market for Chinese goods- more than Pakistan could probably ever be. In November 2006, China signed a free trade agreement (FTA) with Pakistan that aims to triple bilateral trade in the next five years. But Pakistan's GDP growth (around $4.5 \%$ ) is slower than that of India, and the country suffers from instability and inflation. If India maintains its faster development, China might decide to increase its ties to India at the expense of Pakistan, though this is still uncertain: China could see India as a competitor rather than a partner.

The current political situation of Pakistan is another factor that could lead China to become more favourable to India. Pakistan was suspended from the Commonwealth of Nations on November 22, 2007, three weeks after President Musharraf imposed martial law. The assassination of Benazir Bhutto on December 27, 2007, leader of the Pakistan Peoples Party (PPP), also hints that the road to democracy will be long and difficult. Though the PPP emerged as the largest party on February 18,2008 , no political party was able to secure a majority in the Parliament. With Musharraf refusing to resign despite his party's bad results, it is unclear whether the unpopular present will be able to govern the country. The violence of Pakistani politics also seems to have become enduring. For instance, less than one week after the elections, the surgeon general of the Pakistani Army, Mushtaq Ahmad Baid was killed in a suicide attack. Because Pakistan currently gives the impression of an unstable and violent country, India may appear as an increasingly interesting partner to China.

\section{Opportunities for increased regionalism and consequences on the Indo-Pakistani conflict}

China and Japan both wish to increase regionalism in Asia, but they compete as to how to design this regional framework. Since the formation of ASEAN +3 in 1997, Japan has found China's voice too powerful in the forum. In consequence Japan has strengthened its alliance with the US and called for "open regionalism", materialized in 2005 by the formation of the East Asian Summit (EAS) that included Australia, New Zealand and India. The inclusion of India strategically made it more difficult for China to lead unilaterally (Rozman). Moreover, Japan wanted these inclusions to increase the importance of democracy in the framework, hoping to isolate China. This may play out on the Indo-Pakistani issue: If Japan becomes increasingly concerned about supporting democracy in Asia, this will play in the favor of India at the expense of Pakistan.

China, however, perceived that Japan wished to counter its importance, and therefore has become wary of the EAS and of Japan's plan to create a democratic Japan-USIndia-Australia axis. China could try to avoid the formation of such a quadrangle by moving closer to India, distancing itself from Pakistan.

How could India reorganize the region? India's multiple options regarding Pakistan and their consequences

If it is difficult to foresee China's future positioning on the Indo- Pakistani issue, it is because India is itself an increasingly essential actor, capable of choosing how Asia may be reorganized. To become a global power, India must decrease the importance of Pakistan in its strategic thinking, so that "It would not be a question as it is now of Indian power minus Pakistani power, but of an India free to exercise 
its influence over a much wider range" (Cohen). India has many options to do so. First, it could ease the tensions with Pakistan by engaging the country through the multiplication of economic ties. In 2000, trade with Pakistan constituted only $0.21 \%$ of India's total trade, and trade with India was $1.25 \%$ of Pakistan's total trade (Sridharan). More economics links could produce a spill-over into security-issues and put an end to India's paranoia.

Other options seek not to engage but on the contrary to further isolate Pakistan to diminish its strategic importance. India can continue to engage China hoping that it will abandon Pakistan. If India manages to untie the Sino-Pak "entente cordiale", Primakov's concept of an India-Russia-China triangle of cooperation might even become successful.

Alternatively, to push aside the burden of Kashmir, India could make better use of the existing regional frameworks: It could develop continental ties with the SCO and maritime ties with the EAS to isolate Pakistan.

Last, India could isolate Pakistan by becoming closer to Japan at the expense of China. Eventually it could form a democratic axis US- Japan- Australia- India to isolate non-democratic countries such as China and Pakistan. India could then loosen its "one China foreign policy" and develop closer ties to Taiwan. "A healthy relationship with Taiwan will not only further its own strategic and economic interests but also checkmate
China"(Nanda).

These different options show that India has become the "swing state" (Gupta) that can make important decisions about the reorganization of Asia. Yet when choosing among these options, India will surely examine which one offers the most guarantees against the Pakistani threat- only then may India become an Asian power.

The "Pakistani factor" has been the main concern shaping India's foreign policy since 1947. China has recognized the structural nature of the Indo-Pakistani enmity and exploited it to its advantage. With the end of the Cold War, the nuclear tests and the War on terror, the conflict's very nature has changed and China has adapted its stance on the conflict to its evolving strategic interests. Current issues of importance, such as economic development and regionalism suggest that China may choose a stance more favorable to India at the expense of Pakistan. But this will depend critically on India's own strategic choices. India has indeed increasingly become an actor, "a swing state" capable of choosing among different options for the reorganization of Asia which one will best diminish Pakistan's strategic importance. Only once India becomes less "Pakcentrik" will India be able to become an Asian power and find "its rightful place in the emerging world order."

\section{Works Cited}

-Andersen, W., Recent trends in Indian foreign policy, Asian Survey, Vol 41, 2001

-Andersen, W. South Asia: a selective war on terrorism IN Strategic Asia 2004-05, ed. by A. Tellis et al, Washington, DC: National Bureau of Asian Research, pp. 227-59

-Bouton, M, Oldenburg,P. India Briefing, A transformative fifty years, 1999

-Cohen, S. India : Emerging Power, Brookings Institution Press, 2001, Washington

-Deepak B.R., Sino-Pak "Entente Cordiale" and India : A look into the Past and future. China Report, 2006

-Gill, J. India and Pakistan IN Strategic Asia 2005, Seattle, WA: National Bureau of Asian Research, 2005/05, pp. 237-267

- Gupta, A., US-India-China, Assessing Tripolarity, China Report, 2006 Vol 42, New Delhi

-Limaye, S.P, Tokyo's Dynamic Diplomacy: Japan and the Subcontinent's Nuclear Tests, Contemporary Southeast Asia, Vol. 22,2000

-Lounev, S. Russian-Indian relations in Central Asia IN Islam, oil and geopolitics, ed. by E. Davis et al., Lanham, MD: Rowman and \&Littlefield, 2007, chapt. 12, pp. $173-86$

-Malik, M., The China factor in the India Pakistan Conflict, Parameters, 2003

-Nayar, B. India in 2005: India rising, but uphill road ahead Asian survey, vo. 46, no. 1, Jan/Feb 2006, pp. 95-106

-Nanda, P., India and its Taiwan Policy, China Brief. Vol 3 , 2003-Raman, B., India, Japan \& China, talk delivered on April 27, 2007, South Asia Analysis group

-Rajamony, V., India-China- US triangle, A soft Balance of Power System in the Making? Centre for Strategic and International Studies, 2002

-Rozman, G., Japanese strategic thinking on Regionalism, IN Japanese Strategic Thought toward Asia, edited by Gilbert Rozman et al, New York, NY: Palgrave Macmillan, 2007

-Sinha, S., The Strategic Triangle India China Pakistan, China Report, 2004

-Sridharan, E.Improving Indo-Pakistan relations; international relations theory, nuclear deterrence and possibilities for economic cooperation, Contemporary South Asia, September 2005 


\section{The Russian Government and Gazprom}

\section{A Brief Economic Analysis of Russia in the post-Soviet Years:}

Following the collapse of the Soviet Union, the newly-formed Russian Federation faced a considerable economic downturn. During the post-Soviet economic collapse spanning from 1991 to 1998, Russian gross domestic product (GDP) fell from $\$ 509,381,640,192$ to $\$ 270,953,119,744$ (current US dollars). ${ }^{1}$ These figures represent a decline of $\$ 238,428,520,448$ or approximately $46.8 \%$ of the total GDP. This proverbial collapse of the Russian economy was largely due to changing incentives within the Russian market as it evolved from communism to capitalism. Further economic troubles ensued in 1998, spurred by a global recession resulting from the Asian financial crises of 1997. This fallout translated across economic markets; economies relying on the export of raw materials such as oil and natural gas were particularly affected as the price of oil reached a low of $\$ 8$ per barrel.

The financial collapse that gripped Russia in the 1990s was the result of multiple factors. Preceding the impact of the Asian economic woes, Russia only had one year of economic growth: 1997. Beginning in 1999, following a multinational effort to stimulate the Russian economy, Russia has enjoyed a period of economic growth that finally stabilized underVladimir Putin's administration at levels between $5 \%$ and $7 \%$ per year. This article seeks to correlate economic and social policy data, particularly focusing on the growth of Gazprom since 1998 and the Putin administration's restrictive media policy as it affects freedom of expression. We argue that the Russian government's restriction of media and the nationalization of Gazprom, a key element of Russian economic growth policy, are not mutually exclusive. The purpose of this paper is not to judge underlying oligarchic tendencies and the restriction of social policy as they augment the growth of the Russian economy, but rather to prove the existence of these trends using data acquired following the collapse of the Soviet Union.

\section{The Rise of Gazprom}

In his 2004 annual address to the Federal Assembly of the Russian Federation, Putin stated that doubling the GDP of Russia was a national goal over the course of the next decade:

\begin{abstract}
"Whether or not we can become a society of truly free people - free both economically and politically - depends only on us. Reaching our priority national goals depends only on us. These goals are well-known: doubling our gross domestic product over the next decade..."
\end{abstract}

By 2004, Russia's GDP growth rate had already stabilized at a healthy $5-7 \%$, but by 2007 the GDP had almost doubled from 590.71 billion USD in 2004 to 1.04 trillion USD. ${ }^{2}$ This abrupt improvement in economic performance contrasts starkly with the policy consensus following Putin's speech. In 2004, Ksenia Yudaeva of the Carnegie Endowment for International Peace noted that Putin's ambition for Russia's GDP was "a goal met with considerable skepticism by most economists." ${ }^{3}$ In the years between 2004 and 2007 there must have been a significant driving force behind Russia's surprising economic performance. We 
contend that Gazprom, an oil and gas giant now controlled by the Russian state, is partly responsible for this significant economic turnaround as measured by the correlations between Gazprom's economic performance and the performance of the Russian economy abound. The energy conglomerate provides almost $25 \%$ of the Russian government's tax receipts, and as of 2006 accounted for $9.6 \%$ of Russia's GDP. ${ }^{4}$

Gazprom has been subject to scrutiny almost from its inception. The Financial Times notes that the company was "[c]reated from the Soviet ministry of gas [and] has retained many features of a centrally planned economy," and the Organization for Economic Cooperation and Development asserts that "it can at times be difficult even to identify where the state budget ends and Gazprom's begins." ${ }^{\prime 5}$ Despite these undercurrents of suspicion, Gazprom underscored its intentions to privatize by offering Depositary Shares on a London exchange in addition to issuing stock on the Russian market. However, a series of events following Putin's election tipped Gazprom's future development back into the hands of the Russian government.

In 2001, after a series of scandals involving unpaid taxes, Gazprom's board of directors appointed Alexei Miller, a former Putin aide, as CEO. Recently, Miller has asserted that, "Specifically due to a prompt development of Gazprom's business in recent years we have probably a keener sense than our colleagues and partners of the disaccord between the existing 'rules of the game' in the energy sector and present-day challenges facing the global economy." ${ }^{\prime 6}$ Gazprom's growth, which we find to be facilitated in part by collusion with the Russian government, provides evidence that Miller's "present-day challenges" necessitate a serious change in the "rules of the game."

\section{Recent Developments in the Russian Oligarchy}

The year 2004 saw the disintegration of Yukos, a privatized Russian petroleum company. The abrupt collapse resulted from a political dispute in which the company's CEO backed an opposition political party, a move that triggered a sudden torrent of taxes to drive Yukos into bankruptcy. Shortly thereafter, Gazpromand Rosneftegaz, a Russian state-controlled petroleum conglomerate, absorbed the company's assets. ${ }^{7}$ In 2005, the most striking evidence of oligarchic tendency in the Russian government manifested itself through the purchase of $10.74 \%$ of Gazprom by Rosneft, also a state-owned petrochemical company. ${ }^{8}$ This purchase brought the Russian state's ownership of Gazprom to its current $50.002 \%$ majority stake. In exchange, the company liberalized foreign ownership rules for the remaining half of its shares. ${ }^{9}$

Gazprom proceeded to purchase Sibneft, a Russian oil company, as well as a significant portion of former Yukos assets and interests. ${ }^{10}$ The partial takeover of Royal Dutch Shell's Sakhalin-Il project in 2006 followed in response to Russian officials' revocation of Shell's environmental permit. ${ }^{11}$ Combined, these transactions created a swell of foreign interest in Gazprom that resulted in an extreme increase in valuation between 2004 and 2006. Its market capitalization soared from 54.24 billion USD in 2004 to 270 billion USD by the end of 2006. ${ }^{12}$ The combination of these developments underscores the extensive control that the Russian state exerts over its petrochemical industry. Noting Gazprom's significant contribution to the Russian GDP, it can be understood that its performance and its renationalization were crucial to Putin's execution of his stated goals.

\section{Russia and the Media}

According to a 2005 US State Department Report on Human Rights, the Russian government owns a majority share in Channel One, the largest Russian television channels, and directly owns the television station Rossiya, the second largest Russian television channel. ${ }^{13}$ In addition, through its holdings in Gazprom, the Russian 
government owns a majority share of Independent Television (NTV), Russia's third largest television channel. Masha Lipman of the Carnegie Endowment notes that one quarter of all Russians receive only the top two channels, and that Channel One is included in a list of assets strategic to the Kremlin. ${ }^{14}$ It appears that government control has spread to print media as well. According to the same report by the Carnegie Endowment, the state owns $20 \%$ of all national media outlets and $80 \%$ of all regional media outlets.

Raf Sharikov, former editor of the eminent Russian newspaper Izvestiya, experienced the government crackdown on media firsthand. According to an interview with the British Broadcasting Corporation (BBC), Sharikov submitted a forced resignation shortly after Izvestiya printed a story regarding the Beslan School siege questioning official casualty figures. ${ }^{15}$ Allegedly, Izvestiya received multiple phone calls from prominent figures within the Kremlin, including one from the president's spokesperson, calling "for blood" for challenging state figures. Rather than see his team of journalists fired (as was the case at NTV for refusing pro-government changes), Sharikov resigned. This assertion of governmental control occurred in 2004. In June of 2005, Izvestiya came under full control of the Russian government after being acquired by Gazprom's media division.

The amount of influence that the Russian government and state-controlled corporations exert on the media could potentially lead to limitations on the ability of Russian citizens to access critical information. Referring to a news article in which a gang came under arrest for slaying 40 people in an urban district, Raf Sharikov explains, "The news told me they were arrested and punished. But I didn't hear, for a year before that, stories about this gang terrorising the population. That's the manner of the news presented." In this example, the governmentinfluenced media only reported the positive situation: the gang's arrest. Other examples of government influence within the Russian media exist within Putin's own press corps. The Russian president travels with his own handpicked press pool. This creates an illusion of transparency between the government and the people. By having hand-selected members of a press corps at its disposal, the government is effectively filtering information flow through the Russian media. Putin understands the efficacy of using the Russian media to spread consensus among the Russian people and he uses this strategy well.

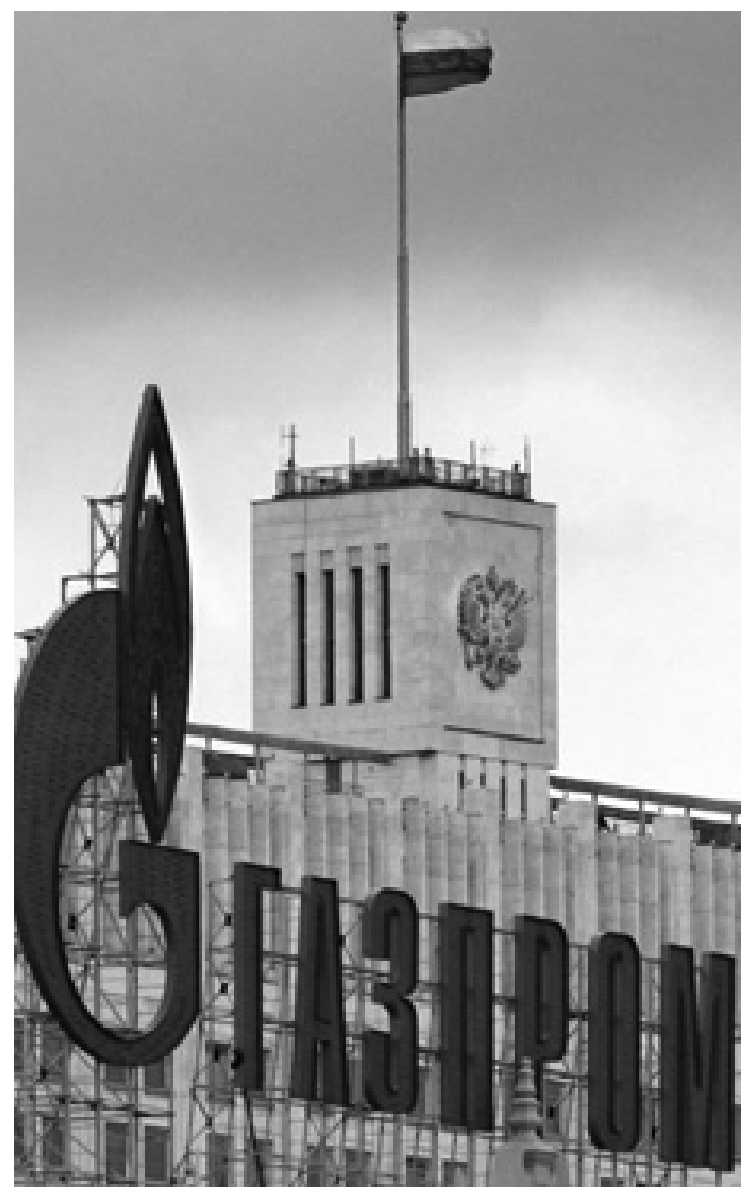

\section{Correlation in the Data}

The common factor between the Russian media and companies such as Gazprom is an attitude of state intervention in the public domain. Noting the percentage of GDP that Gazprom contributes to the 
Russian economy, it is within Russian interest to control information regarding the economy and thereby elicit economic growth in Russia. The means of doing so is available. The oligarchic structure of the Russian economy is evolving as the government assumes the role of master oligarch in the Russian energy trade as well as the Russian media. Given that the state-controlled Russian media goes to great lengths to censor the negative aspects of events such as gang slayings, we have reason to believe that this media establishment withholds or ignores information regarding negative aspects of corporate growth within Russia.

In the early days of post-Soviet Russia there was much ado over the enumeration of the rights of the Russian population. The new Russian constitution sought to concretely guarantee a dimension of personal and national freedom that was absent from the Soviet Union. Under Putin's program of economic growth, a disparity has emerged between this form of expansion and the rights of the Russian people, as illustrated by violations of at least two particular sections in the constitution.

The Russian government is refuting that the constitution meant to dictate how it should govern, particularly by contradicting the provisions of articles 29 and 34. Quoting a section of Article 29, "Everyone shall be guaranteed freedom of thought and speech...Propaganda shall also be prohibited...The freedom of the mass media shall be guaranteed. Censorship shall be prohibited." ${ }^{16}$ Arguably while this freedom still exists due to a lack of government ownership of all media outlets, there is a conflict of interest at foot. Notwithstanding the lack of outright government ownership, the Russian government controls the top three television stations in Russia, handpicks the Kremlin press corps, and exerts pressure on non-government owned media. Article 34 states, "1. Everyone shall have the right to use freely his (her) abilities and property for entrepreneurial and other economic activity not prohibited by law. 2. Economic activity aimed at monopolization and unfair competition shall not be permitted."17 Gazprom itself is an example of a monopoly that has grown with direct support from the government. While it is easy to see how the overall Russian economy may benefit from state-controlled corporations and media control, it is arguable that state control, by allowing Russia to become better off economically, has cost the Russian people the validity of their constitution.

By directly shedding the constraint of article 34 and subversively maneuvering around article 29 of the constitution, the Russian government endangers its legitimacy. Despite this, the majority of Russian people are enjoying greater prosperity than ever before. This must lead us to question if there is a price that people should put on their rights. It is morally ambiguous to say that one argument or another is correct in this case. The state does not own all media outlets and does not control all corporations. Those that the state has in its hand, however, are profiting quite well, and it appears that the Russian government has taken action to allow corporations such as Gazprom to monopolize entire industries. The Russian government directly benefits from good performances by firms like Gazprom on both national and international markets. This translates to taxes and dividends for the Russian government as well as increased economic activity within the country. It is within the best interest of the Russian government to combine media control with industrial monopolization to elicit further economic growth, and it is our hope that the international community becomes more aware of this correlation. 


\section{Endnotes}

${ }^{1}$ World Development Indicators. World Bank. [Online Resource]. Retrieved October 27th 2007 , from http://www.worldbank.org

${ }^{2}$ World Economic Outlook Database. IMF. [Online Resource]. Retrieved October 27 ${ }^{\text {th }}, 2007$, http://www.imf.org/external/pubs/ft/weo/2007/02/ weodata/index.aspx

${ }^{3}$ President Putin`s Address to the Parliament: a Statist-Liberal Mixture. Ksenia Yudaeva (Carnegie Endowment for International Peace). [Online Resource]. Retrieved October 27 ${ }^{\text {th }}, 2007$, http://www.carnegie.ru/en/print/70671-print.htm

${ }^{4}$ Gazprom in Figures 2000-2006. Gazprom. [Online Resource]. Retrieved November 16 ${ }^{\text {th }}, 2007$, http://www.gazprom.com/documents/Stat Report Eng.pdf

${ }^{5}$ Gazprom Acts as Lever in Putin's Power Play. Hermitage Capital Management. [Online Resource]. Retrieved November 16 ${ }^{\text {th }}$, 2007, from http:// hermitagefund.com/index.pl/news/article.html?id=788

${ }^{6}$ The Process of Gazprom's Conversion from the "National Champion" into a Global Energy Business Leader has been Completed.Gazprom. [Online Resource]. Retrieved November $16^{\text {th }}, 2007$, from http://www.gazprom.ru/eng/articles/article24271.shtml

${ }^{7}$ Gazprom, Rosneft: Divided in Unity. International Relations and Security Network (ISN). [Online Resource]. Retrieved November 16 ${ }^{\text {th }}, 2007$, from http://www.isn.ethz.ch/news/sw/details.cfm?ID=16607

${ }^{8}$ Gazprom in Figures 2000-2006. Gazprom. [Online Resource]. Retrieved November 16 ${ }^{\text {th }}, 2007$, http://www.gazprom.com/documents/Stat_Report Eng.pdf

${ }^{9}$ Gazprom Opens Doors to Foreigners. BBC. [Online Resource]. Retrieved November 16 ${ }^{\text {th }}, 2007$, from http://news.bbc.co.uk/2/hi/business/4618163. $\underline{\text { stm }}$

${ }^{10}$ Gazprom Scoops up Sibneft for $\$ 13$ Billion. Johnson's Russia List. [Online Resource]. Retrieved November 16 ${ }^{\text {th }}, 2007$, from (http://www.cdi.org/russia/ johnson/9258-5.cfm)

${ }^{11}$ Gazprom, Shell, Mitsui, Mitsubishi sign Sakhalin II protocol. Mitsui \& Co., Ltd.. [Online Resource]. Retrieved November 16 ${ }^{\text {th }}$, 2007, from http://www. mitsui.co.jp/en/release/2006/1176280 1210.html)

${ }^{12}$ Gazprom in Figures 2000-2006. Gazprom. [Online Resource]. Retrieved November 16, th 2007, http://www.gazprom.com/documents/Stat Report Eng.pdf

${ }^{13}$ Russia, Country Reports on Human Rights Practices 2005. U.S. Department of State. [Online Resource]. Retrieved November $16^{\text {th }}$, 2007, from http://www.state.gov/g/drl/rls/hrrpt/2005/61671.htm

${ }^{14}$ Russia's Overmanaged Democracy: What the Kremlin Has substituted for Emasculated Institutions. Carnegie Endowment for International Peace. [Online Resource]. Retrieved November $16^{\text {th }}, 2007$, from

(http://www.carnegieendowment.org/events/index.cfm?fa=eventDetail\&id=982\&\&prog=zru

${ }^{15}$ Viewpoint: 'Soviet' grip on Russian media. BBC. [Online Resource]. Retrieved November 16 ${ }^{\text {th }}, 2007$, from (http://news.bbc.co.uk/2/hi/europe/4043389. stm)

${ }^{16}$ The Constitution of Russia. President of Russia Official Web Portal. [Online Resource]. Retrieved November $16^{\text {th }}, 2007$, from (http://www.kremlin.ru/eng/articles/ConstEng2.shtml)

${ }^{17}$ The Constitution of Russia. President of Russia Official Web Portal. [Online Resource]. Retrieved November $16^{\text {th }}, 2007$, from

(http://www.kremlin.ru/eng/articles/ConstEng2.shtm 


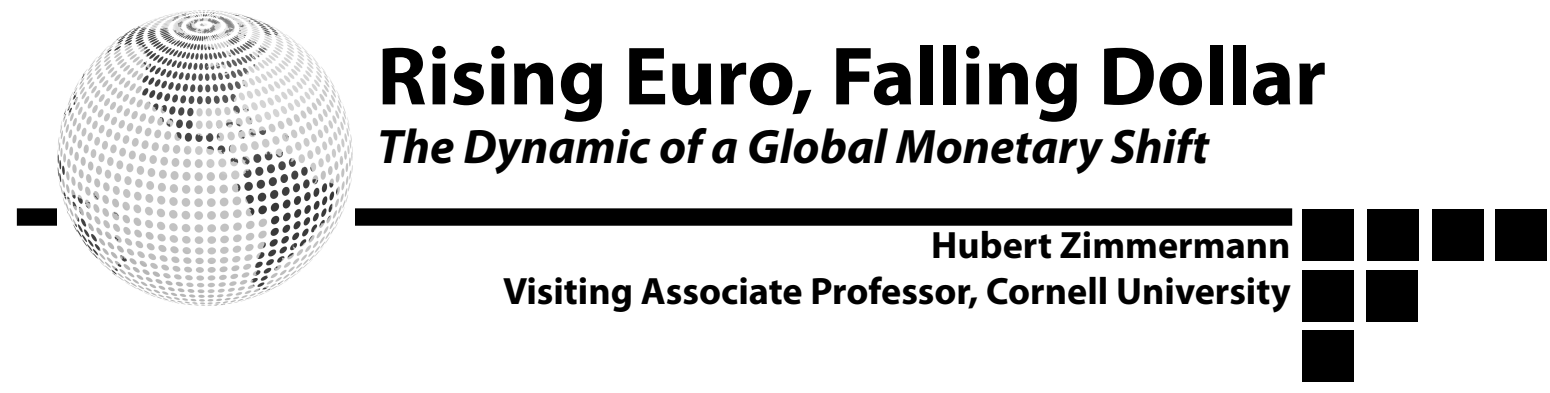

In the past weeks, print media and blogs are buzzing with renewed speculation about a possible replacement of the Dollar as the dominant global currency by the Euro. This intensification of the debate was sparked by the rise of the Euro above $\$ 1.50$ and a corresponding fall of the Dollar, also against other currencies. Even one Canadian Loonie is now worth more than one US Dollar. Numerous working papers and studies have been written since the late 1990s which present various arguments for either optimistic or pessimistic assessments of the Dollar's continued preeminence as a credible competitor to the Euro. Most of them focus on various economic indicators, while political scientists have tried to identify the political factors which might lead to a change of order in the global pyramid of currencies (Cohen 1998). ${ }^{1}$ Relatively few of these studies deal with the likely consequences of such a shift, apart from wide-ranging and broad assertions which often reflect the predilections of the authors. What does it mean for international politics if the Dollar loses its preeminent position? What are the consequences for the domestic economies of either declining or rising currencies? This article will present some reflections on these questions, making use of recent advances in the study of international monetary policy and identifying some of the areas which necessitate more research.

\section{Crouching Euro: Indications for the Leap Forward}

It is generally accepted that a global currency needs some attributes to arrive at and stay in such a position. The first and foremost necessity is solid confidence by market participants in its value. It has to be backed by an economy which guarantees political stability and low inflation (de Grauwe 2007: 253-4). Second, the currency has to provide deep, liquid, and efficient financial markets to guarantee easy access to capital and to allow market participants flexibility in the choice of instruments. Third, it must be internationally accepted almost everywhere. History suggests a fourth condition: the country issuing the currency should also be the dominant, or at least one of the dominant, political and military powers of the world. If these conditions are given, the currency might become the global leader in the core functions of international money as unit of account (vehicle currency), medium of exchange (transaction currency), and store of value (reserve currency).

Since 2001 the Euro has been on a slow but almost uninterrupted upward path against the dollar. From a low of about 0.82 $\$ / €$ it is now well on its way to almost double its value against the dollar. This rise, however, is not necessarily an indication of a switch in the global currency balance: massive swings of exchange rates happened before, and the fluctuations of the Dollar against the German mark (DM) were just as extreme without the latter becoming a major reserve currency. Yet, it is clear that the Euro plays in a different league from the DM. This is not only due to the size of its market (15 countries with a population of 320 million), but also because the European Union, most of whose members will eventually adopt the Euro, has made no secret of its ambition to become a global actor, not only a regional one as Germany was. The rise of the Euro suggests to participants, 
whether individuals, firms, or states, that holding Euros might be more profitable than holding Dollars. In fact, according to the latest IMF figures, the share of Dollars in total official reserves diminished from $71.5 \%$ in 2001 to $64.7 \%$ in 2006, and the share of the Euro rose from $19.2 \%$ to $25.8 \%$ (IMF 2007). Clearly, this is also an indication that the Dollar still reigns supreme as reserve currency, but if that trend continues, the Euro will overtake the Dollar in about 15 years which would be quite rapid in terms ofmonetaryhistory. Numerouscountries have indicated they are contemplating a shift in their reliance on the Dollar as dominant reserve asset. ${ }^{2}$ These developments make scholars speculate increasingly about an imminent reversal of the global roles of the Euro and the Dollar. Chinn and Frankel (2006) argue that either continued inflation in the US and the resulting Dollar depreciation, or an expansion of the Eurozone to most EU members, most crucially Britain, would signal the end for the preeminence of the Dollar.

Shifts are also on the way regarding the use of the Euro as vehicle currency. Recently, OPEC countries discussed openly whether they should switch from pricing oil in Dollars. Most members still reject such a step which could send the Dollar even lower and potentially make energy imports more expensive for the U.S. (Blas and Crooks 2007). As of yet, chances for such a drastic step seem low, and most international commodities are still invoiced in Dollars.

The amount of Euro notes in circulation has exceeded the value of Dollar notes since the end of 2006 (Atkins 2006). Despite that, the Dollar is still the world's leading transaction currency, being part of $86 \%$ (out of $200 \%$ because two currencies are involved) of global transactions. Overall, as the last report of the European Central Bank on the issue concludes, the international role of the Euro is still characterised by a strong institutional and regional pattern' (ECB 2007). What are the prospects for a change in the near future?

\section{Hidden Dollar: The Residual Strength of the Top Currency}

Despite the indications for a rising role of the Euro, the majority of analysts remain skeptical that the Dollar will lose its top position. With reference to the decades it took the Dollar to replace the Pound, long after Britain had lost most of its political clout, the inertia of changes in the monetary system is often cited as a major reason why the fall of the Dollar is not imminent. The pathdependency of an established currency which market players are used to, creating what political scientists call 'network externalities' and 'functional synergies', serves as a strong pillar bolstering the Dollar. Economists Dooley, Folkerts-Landau and Garber (2003) have argued that the world is experiencing what they call a Bretton Woods II system. The original Bretton Woods system was stabilized by the willingness of key follower countries to hold Dollars and finance the American deficits because they had an overriding interest in the competitiveness of their exports. This role is now assumed by the big emerging market economies which depend on exports for economic growth. In an influential article, one of the leading IPE scholars, Benjamin Cohen, offered basically four reasons why the Euro will not surpass the Dollar in the foreseeable future (2003). First, the efficiency of Europe's financial markets is still way behind American markets, and the Eurozone has no instrument to rival the convenience of the US Treasury bill. ${ }^{3}$ Second, an alleged anti-growth bias is built into the Eurozone, given the focus on monetary stability. Third, the political structure of monetary decision-making in the Eurozone remains ambiguous. It is still unclear who represents the Euro in the international arena: the ECB, ECOFIN, or the newly appointed Mr. Euro, Prime Minister Juncker of Luxembourg? Even more serious, and this might be the most fundamental reason of all, is the fact that the Euro is not backed by a unified political structure. Doubts about its longevity are bound to linger. This leads directly into the question 
of the sustainability of the Euro. What happens to the Eurozone if countries such as Italy would be forced to leave (Tilford 2006)? While this seems a far-fetched scenario at present, it might become more relevant as international investors weigh the consequences of a longterm shift to the Euro. In contrast, nobody seriously speculates about a break-up of the United States. The bottom line is that the Euro still has to overcome some serious obstacles before it achieves parity with the dollar.

\section{Monetary Power: "Real Sharpness comes without Effort." ${ }^{4}$}

Does it matter if the Euro becomes a global currency and the Dollar gets a rival? This question ultimately hinges on the economic and political gains which the Eurozone countries and their citizens would derive from that change and, of course, also from the advantages the United States would have to forego. Again, estimates are diverging because there are no clear measures of the advantages and disadvantages of global reserve currencies for their issuing countries. The most obvious advantage of a global currency is the gain from so-called seigniorage. As other nations hold the global currency at no interest (for example, as Dollars kept under a mattress), they effectively extend a zero-interest loan to the issuing country. However, in terms of global financial power this effect is generally assumed to be relatively small (Kenen 2003: 265). Another advantage lies in the lower exchange rate risk for companies located in the core country. States owning a global currency can also, under certain conditions, use it to exert direct pressure on other states (Kirshner 1995). Finally, there is the 'exorbitant privilege' of financing deficits with liabilities denominated in the home currency, though this might well become a weakness over the long run (De Beaufort Wijnholds/McKay 2007: 61). The US all through the post-war was able to borrow short and lend long, continuously earning a higher income on its liabilities abroad than foreigners earned on their generally low- yielding dollar assets. As Gourinchas and Rey (2005) demonstrate, even when US liabilities exceeded its assets by a considerable margin, the US recorded a substantial net income. In case of a Dollar devaluation, the US also profited from an exchange rate effect as Dollar-holders' reserves shrank whereas US investments abroad rose in value.

It has to be stated, however, that there might be also drawbacks in a currency's global dominance More demand for a global currency can drive up the exchange rate, threatening exporters. Incontrollable currency holdings by foreigners can make the control of the money supply difficult, especially in the case of sudden swings in market sentiment. This was one of the major reasons why the German central bank, the Bundesbank, always looked with uneasiness at any indication of the DM becoming a major international currency. Its core mandate was to control domestic inflation and huge DM deposits abroad threatened to undermine it. The same is of course true for the Eurozone, and the European Central Bank (ECB) has maintained that it would neither promote nor hinder the development of the Euro as global currency. In fact, if the ECB had to tighten its policy in response to external influences, this might create enormous strains in some Eurozone countries (Tilford 2007). Thus, the question whether a global currency actually conveys tangible advantages to the issuing country (apart from the not unsubstantial factor of prestige) hinges on whether it actually serves the objectives of the country (and those of its firms and citizens) and whether it enhances the country's power to pursue its objectives.

This brings us to the question of monetary power. In a recent path-breaking volume on monetary power, B. Cohen defined its essence as 'the relative capacity to avoid the burden of payments adjustment, making others pay instead' (Cohen 2006: 50). The ultimate measure of monetary power is the ability to pursue one's goals without regard to the effects on others. Potential adjustment 
costs will fall on other participants, since opting out of the monetary system is no option for practically all market participants. The one red thread running through any analysis of US monetary policy since the ascendancy of the Dollar is the American unwillingness to subject domestic economic strategies to movements on global currency markets. There have been exceptions, notably during the 1960s when, for reasons related to the cohesion of Cold War alliances, the US implemented various restrictions on its international monetary transactions, negotiated deals with allies, and participated in a series of international mechanisms, all designed to bolster the Dollar (Zimmermann 2002). But the essential fact is that the US didn't have to adjust. This autonomy for the most part was not based on a conscious strategy. Despite some conspiracy theories, ${ }^{5}$ there are few indications that the US actively tried to promote or preserve the status of the Dollar. The most frequently cited episode is described by David Spiro who maintains that US protection of the oil-rich gulf countries such as Saudi Arabia hinges on a quid-proquo of these countries to support the Dollar and American consumption (Spiro 1999). But that seems to be clearly an exception. It was much more important that other countries had to react to the effects created by various policy choices in the center country, whether that suited their preferences or not.

Europe with its integrating markets, which necessitate a high level of exchange rate stability, suffered particularly from these fluctuations (Zimmermann 2008). Doubtlessly, the introduction of the Euro has made the Eurozone much more autonomous in this sense. Exchange rate fluctuations such as the fall of the Dollar in the past years would have led to incessant asymmetric adjustment pressure on European currencies, whereas in the current situation Europe has suffered remarkably little impact, apart from exports to the Dollar area which have not yet reached the pain threshold. In that sense, the Eurozone has acquired the core attribute of monetary power.
Just as the US was able to pursue its major objective, that is, to ascertain a continuous inflow of capital without inflation or other adjustment pressures, the Eurozone has been able to pursue its objective of macroeconomic stability. Much more research is necessary to exactly clarify the links between the international role of the Euro and its possible effect on domestic economic (and therefore political!) conditions in the Eurozone. The contest about which is the real global currency will be decided once a major crises forces the major cost of adjustment on either the US or Europe (almost certainly, innocent bystanders will suffer considerably more than the big players).

\section{Green Destiny? Possible Consequences of Monetary Bipolarity}

We might live already in a world of a monetary bipolarity. There are few historical parallels for such a situation. The most plausible comparison is the interwar period between World War I and II, when the British pound was in decline whereas the Dollar was ascendant. Obviously, this was a period of rampant international financial instability. Can this be attributed to the absence of a clear top currency? This was the claim of hegemonic stability theory: without a hegemon providing a minimum of public goods to overcome dilemmas of collective action, international cooperation would collapse (Kindleberger 1973). This much maligned theory was actually developed with monetary policy foremost in its mind but its opponents usually point to the 1970s and 1980s when the US lost its dominance in trade but kept its monetary leadership.Thus, it mightfinally face a real world test. However, even if the world descended into instability this would not necessarily rescue the theory, since the US in monetary policy rarely exerted leadership for the sake of systemic stability. Frequently, it has been the source of instability. The noted economist Barry Eichengreen, who has studied the interwar period extensively, attributes many 
of the problems not to monetary bipolarity but rather to the absence of functioning institutions for international coordination and an unwillingness to cooperate among the major players, caused by domestic pressures (Eichengreen 1995: 8-12).

Currently, monetary relations are characterized by a very low level of formal cooperation. The G8 is ineffective in this area, the IMF is limited to a surveillance role, and Central Bank cooperation occurs mainly adhoc, such as during the recent credit crunch caused by the subprime mortgage crises. Such Central Bank cooperation, in the framework of the Bank for International Settlements and the Financial Stability Forum, tends to be rather non-controversial in case the solutions involve benefits for all participants and negligible adjustment costs. Once a distributive dimension enters the game, political conflict is unavoidable. At this point, the destiny of the greenback could easily result in the often evoked battle between the Dollar and the Euro. There is a clear danger of all participants losing if a duopoly in monetary policy leads to instability without working mechanisms to address monetary crises.

\section{Endnotes}

'Since 'Money is Politics', as Jonathan Kirshner (2003) reminds us, it makes little sense to focus exclusively on economic determinants when dealing with international monetary issues.

2'India seen cutting its dollar reserves', FT, May 4, 2005;'Diversification Specter Unnerves the Dollar', International Herald Tribune, Mar. 17, 2005.

${ }^{3}$ However, the adoption of the Financial Services Action Plan (FSAP) by the EU in March 2000 has been a big step in creating a single financial market. It aims to remove regulatory and market barriers to the cross-border provision of financial services in the EU. There are already some indications that European markets have made substantial progress in catching up with the US.

${ }^{4}$ Quoted from: Crouching Tiger, Hidden Dragon (2000), directed by Ang Lee.

${ }^{5}$ Among the most frequently cited on the internet is the wildly implausible theory that the US marched into Iraq to punish Saddam Hussein for switching to the euro.

\section{Works Cited}

Atkins Ralph (2006), 'Euro Notes in Cash to Overtake Dollar', Financial Times December 26.

Blas Javier/Crooks Ed (2007), 'OPEC Looks at Switch to a Strong Currency', Financial Times, Nov. $19,2$.

Chinn Menzie David and Jeffrey A. Frankel (2006), Will the Euro Eventually Surpass the Dollar as Leading International Reserve Currency?, Kennedy School of Government Working Paper, RWP 05-064.

Cohen, Benjamin J. (1998), The Geography of Money (Ithaca, NY: Cornell University Press).

Cohen, Benjamin J. (2003), 'Global Currency Rivalry: Can the Euro Ever Challenge the Dollar?', Journal of Common Market Studies, Vol. 41, No. 4 (September), 575-95.

Cohen Benjamin J. (2006), 'The Macrofoundations of Monetary Power', in: Andrews David M., ed., International Monetary Power, Ithaca: Cornell UP.

De Beaufort Wijnholds J. Onno/McKay Julie (2007), 'Living up to the Expectations? Taking Stock of the International Role of the Euro', in: Roy J./GomisPorqueras P., The Euro and the Dollar in a Globalized Economy (Aldershot: Ashgate), 59-81.

De Grauwe Paul (2007), Economics of Monetary Union, Oxford UP: Oxford.

Michael P. Dooley, David Folkerts-Landau, Peter Garber (2003), An Essay on the Revived Bretton Woods System, NBER Working Paper 9971; http://www. nber.org/papers/w9971.

ECB (2007), Review of the International Role of the Euro, ECB: Frankfurt.

Eichengreen Barry (1995), Golden Fetters.The Gold Standard and the Great Depression, 1919-39, Oxford and New York: Oxford UP

Gourinchas Pierre-Olivier/Rey Hélène, From World Banker to Venture Capitalist: US External Adjustment and the Exorbitant Privilege, NBER Working Paper 11563; www.nber.org/papers/w11563.

IMF (2007), Annual Report, www.imf.org/external/pubs/ft/ar/2007/eng/index.htm (acc. 3/1/2008).

Kenen Peter B. (2003), 囚The Euro and the Dollar: Competitors or Compliments?囚, in: Dumoulin M./ Duchenne G., eds., LखUnion Europénne et les ÉtatsUnis, Bruxelles et.al., PIE $\otimes$ Peter Lang, 251-74.

Kirshner, Jonathan (1995), Currency and Coercion: The Political Economy of International Monetary Power (Princeton: Princeton University Press).

Kirshner, Jonathan, (2003), 'Money is Politics', Review of International Political Economy 10:4 (November), 645-60.

Spiro David (1999), The Hidden Hand of American Hegemony: Petrodollar Recycling and International Markets, Ithaca: Cornell UP.

Tilford Simon (2006), Will the Eurozone Crack? CER Report: London.

Tilford Simon (2007), 'Could the Euro Rule Supreme? It's not worth it', Financial Times, Nov. $27,13$.

Zimmermann Hubert (2002), Money and Security. Troops and Monetary Policy in Germany's Relations to the United States and the United Kingdom, 1950-71, Cambridge UP: Cambridge.

Zimmermann Hubert (2004) 'Ever Challenging the Buck? The Euro and the Question of Power in International Monetary Governance', in: Francisco Torres/Amy Verdun/Hubert Zimmermann (eds.), Governing the EMU, EUI: Florence, 233-48.

Zimmermann Hubert (2008), The Federal Republic and the Transition to Flexible Exchange Rates, in: David Andrews, ed., Orderly Change: International Monetary Relations Since Bretton Woods, Ithaca: Cornell University Press. 


\section{Cornell International Affairs Review}

\section{Corporate Sponsors}

- Atrium Pharmacy Provider, LLC

\section{Patrons}

- Wenceslao and Priscilla Azana

- Bartels Family

- Grace \& Benedicto Cabungcal

- Charo Horhota

- Susan Kalus

- Concepcion R. and Rodolfo M. Leal

- Lencquesaing Family

- Pedraza Family

- Reyes Family

- Schoonover Family

- Singer Family

- Craig Yunker

\section{University Contributors}

- Department of Government

- Department of Near-Eastern Studies

- Department of Policy Analysis

and Management

- Institute for European Studies

- The Mario Einaudi Center for International Studies

- Office of the Vice-Provost for Undergraduate Education

- Student Assembly Finance Commission
Finance Department

- Kevin Schoonover

- Sarah Eversman

\section{Global Networking Department}

- Jeff Aziakou, Global Liaison

- Katherine Reidel, Global Liaison

- Benjamin Barnier, Liaison Officer to McGill University, Canada

- Romain Jouvent, Liaison Officer to Sciences Po, IEP de Paris, France

- Sohaib Perwaiz,

Liaison Officer to Princeton University

- Haroon Ellahi Shaikh, Liaison Officer to Pakistan

\section{Layout Department}

- Cecilia de Lencquesaing

\section{Literary Department}

- Katharine Engelhart, Managing Editor

- Ramya Kasturi, Managing Editor

- Chandni Navalkha, Managing Editor

- Mandy Esch, Associate Editor

- llana Yoffe, Associate Editor

- Tom Naples, Associate Editor

- Elisheva Yun, Associate Editor

- Matt Friedman, Copy Editor

- Jeffrey Javed, Copy Editor

- Marijke Shouten, Copy Editor

- Niyati Thakker, Copy Editor

- Emma Banks, Writer

- Israel Barriga, Writer

- Lee Blum, Writer

- Jennifer Fishkin, Writer

- Preeti Gill, Writer

- Lauren Herget, Writer

- Arthur Neron-Bancel, Writer

- Francis J. Pedraza, Writer

- Amanda Rudman, Writer

- Kevin Schoonover, Writer

\section{Marketing Department}

- Peirce Stern 
Cornell International Affairs Review endeavors to provide the Cornell community with a medium to engage others in discourse on the most current transnational and international issues. It seeks to accomplish this with the establishment of a three-pillared strategy:

To Inspire an interest in issues beyond one's local sphere in undergraduate society by hosting and attending lectures by academics and professionals and of events hosted by the University to supplement one's education in international relations.

To Engage students in the current debate through the establishment of a collaborationbased, biannual journal.

To Provide opportunities for students to become proactive in changing their social and political environments.

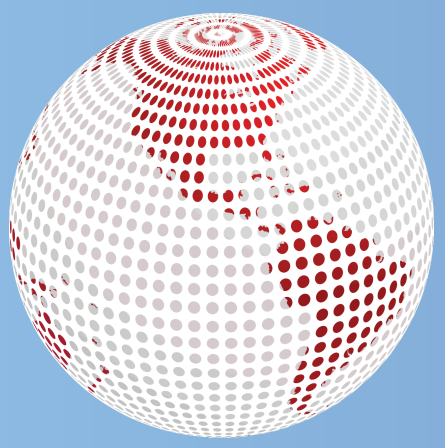

